$$
\text { DOE/PO--7910I }
$$

\title{
Independent Transmission System Operators and Their Role in Maintaining Reliability in a Restructured Electric Power Industry
}

\section{Prepared for:}

U.S. Department of Energy

Office of Economic, Electricity and Natural Gas Analysis Office of Policy and International Affairs Under Contract \#DE-AC01-92PE79101

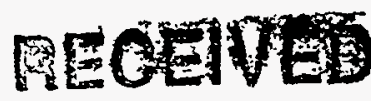

DEC 291997

.) STI

DISTABUTION OF THS DOCUMENT is UATHTEO 
DOE/PO- 79101

\section{Independent Transmission System Operators and Their Role in Maintaining Reliability in a Restructured Electric Power Industry}

Prepared by:

ICF Resources, Inc.

Fairfax, VA 22031

Contract \#DE-AC01-92PE79101

Prepared for:

U.S. Department of Energy

Office of Economic, Electricity and Natural Gas Analysis

Office of Policy and International Affairs

Washington, DC 20585 


\section{DISCLAIMER}

Portions of this document may be illegible electronic image products. Images are produced from the best available original document. 


\section{Preface}

This report reviews current proposals to form Independent System Operators (ISOs) to operate highvoltage transmission systems in the United States and their potential role in maintaining bulk power system reliability. As background, the likely new industry structure, nature of deregulated markets, and institutional framework for bulk power system reliability are reviewed. The report identifies issues related to the formation of ISOs and their roles in markets and in reliability, and describes possible policy options to address those issues.

It should be noted that all of these ISOs are undergoing further definition and revision; the information provided here was gathered in September, 1997. Some of these ISO discussions are in a very early stage. The information on all of these ISOs is based on public information and private conversations, and some of the information may have been misunderstood or misinterpreted.

The views and opinions of the authors expressed herein are not necessarily those of the United States Government or any agency thereof.

This report was prepared under DOE contract \#DE-AC01-92PE79101. 


\section{Contents}

Executive Overview

E-1

The Independent System Operator's (ISO) Dual Charge: Open Access for Transmission,

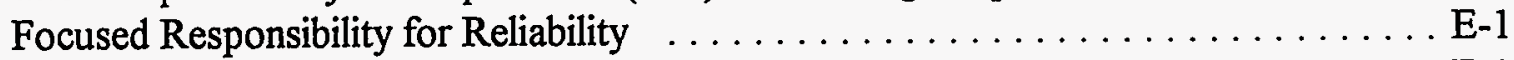

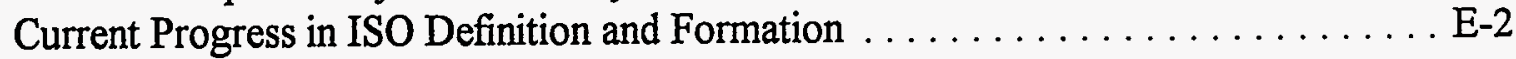

Emerging Characteristics of ISOs . . . . . . . . . . . . . . . . . E-2

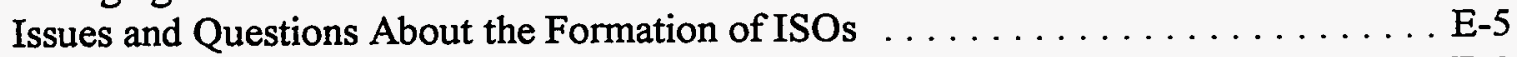

Potential Policy Options for ISOs and Bulk Power System Reliability . . . . . . . . E E-8

1. Background: Maintaining Bulk Power System Reliability in a Restructured,

More Competitive Electric Power Industry: Issues and Initiatives . . . . . . . 1-1

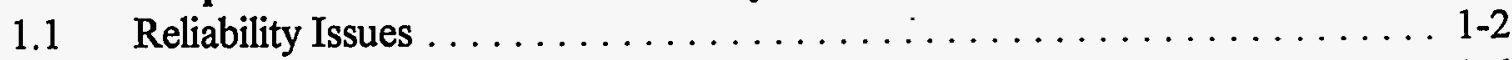

1.2 Possible Organizational Framework for Reliability Management $\ldots \ldots \ldots$. $1-6$

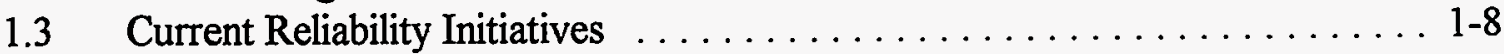

1.3.1 Current North American Electric Reliability Council Initiatives ..... 1-9

1.3.2 The Western System Coordination Council Mandatory Reliability Management System $\ldots \ldots \ldots \ldots \ldots \ldots \ldots \ldots \ldots \ldots \ldots \ldots \ldots . \ldots \ldots$

2. Overview and Comparison of ISOs Underway and Proposed $\ldots \ldots \ldots \ldots$ 2-1

2.1 Bulk Power Competition, Non-discriminatory Transmission Access,

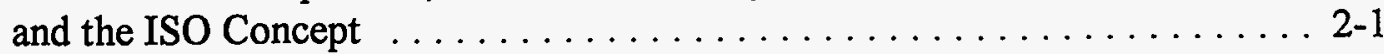

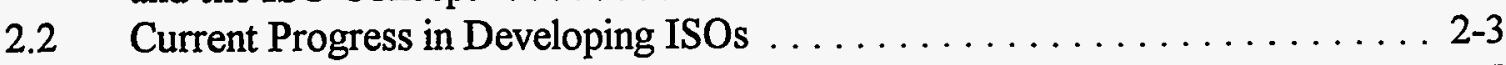

2.3 Characteristics of ISOs Proposed and Underway $\ldots \ldots \ldots \ldots \ldots \ldots \ldots .2-5$

2.3.1 ISO Proposal Development Process . . . . . . . . . . . . 2-5

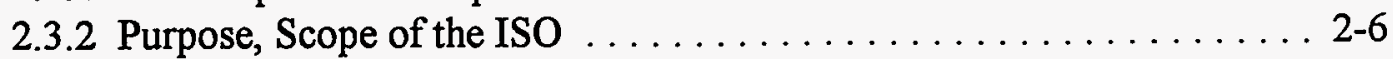

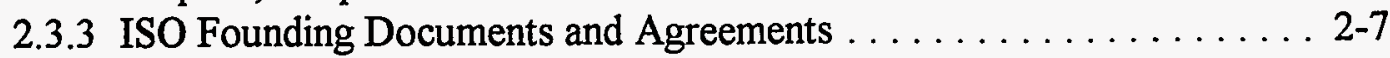

2.3.4 Nature of the ISO Organization $\ldots \ldots \ldots \ldots \ldots \ldots \ldots \ldots \ldots .2-8$

2.3 .5 Governance $\ldots \ldots \ldots \ldots \ldots \ldots \ldots \ldots \ldots \ldots \ldots \ldots \ldots \ldots \ldots \ldots . . .2-9$

2.3.6 Dispute Resolution ........................ 2-11

2.3.7 ISO Control of Transmission $\ldots \ldots \ldots \ldots \ldots \ldots \ldots \ldots \ldots \ldots \ldots \ldots \ldots \ldots .12$

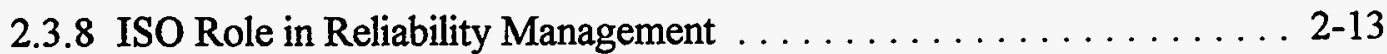

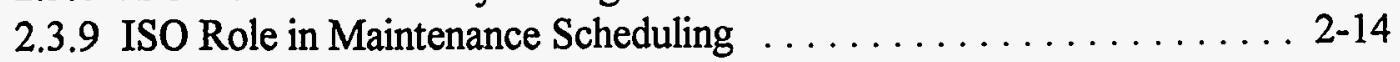

2.3.10 ISO Role in Transmission Access and Pricing ............ 2-14

2.3.11 ISO Role in Congestion Management .............. 2-15

2.3.12 ISO Role in Ancillary Services Provision ............ 2-15

2.3.13 ISO Role in System Planning . . . . . . . . . .

2.3.14 ISO Role in Ensuring Generation Adequacy ........... 2-16

3. ISOs and Their Role in Bulk Power System Reliability:

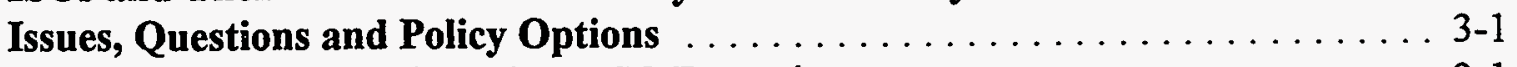

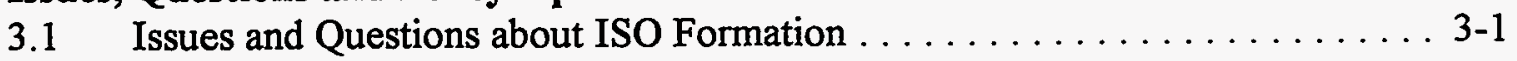

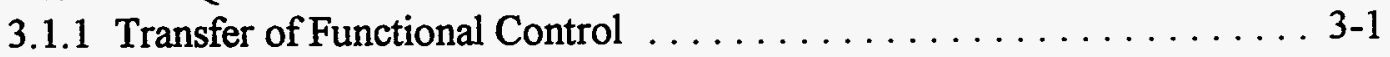

3.1.2 Provision of Non-discriminatory Transmission Access ......... 3-2 
3.1.3 Geographic Sizes and Boundaries of ISOs $\ldots \ldots \ldots \ldots \ldots \ldots$. 3-2

3.1.4 Effectiveness of ISO Governance ................... 3-3

3.1.5 Ability of ISOs to Evolve and Adapt Procedures . . . . . . . . 3-3

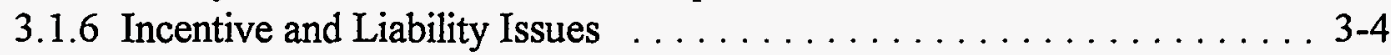

3.1.7 Possible Alternatives to ISOs . . . . . . . . . . . . . . . . 3-5

3.1.8 Role and Performance of ISOs in Reliability Management . . . . . . . 3-5

3.1.9 Effectiveness of Regional Transmission Planning . . . . . . . . . . . 3-6

3.1.10 ISO Interface with Bulk Power Markets . . . . . . . . . . . 3-7

3.2 Policy Options . .................... $3-7$

Appendix A: System Operation Arrangements in Other Countries $\ldots \ldots \ldots \ldots \ldots$.1

Appendix B: Characteristics of U.S. ISO Proposals $\ldots \ldots \ldots \ldots \ldots \ldots \ldots \ldots$ B-1

B.1 Summaries of the Midwest, IndeGO, ERCOT, and DesertSTAR Proposals . . B-2

B.2 Summaries of the California, New England, PJM and NY ISO Proposals ... B-13 


\section{Executive Overview}

This report summarizes the current status of proposals to form Independent System Operators to operate high-voltage transmission systems in the United States and reviews their potential role in maintaining bulk power system reliability. The report raises a number of issues and questions about ISOs and indicates some potential policy directions for encouraging the formation of effective ISOs and ensuring bulk system reliability. ${ }^{1}$

\section{The ISO's Dual Charge: Open Access for Transmission, Focused Responsibility for Reliability}

The United States is moving toward expanded competition in the electric power industry. Competitive markets require open, non-discriminatory access for buyers and sellers to the highvoltage transmission grid. Since the country's vertically integrated utilities are generally not inclined to divest their transmission systems, the concept of an Independent System Operator (ISO) has developed. As proposed, the ISOs will not own transmission, but will control transmission under agreement with the owners; they will be independent of the utilities in other respects and of all other market participants; and they will provide transmission access on a non-discriminatory basis, thus facilitating competition.

Concurrent to the development of the ISO concept as a solution to the open access problem, attention to bulk power system reliability has been increasing. This has been due partly to the outages in the western part of the country in the summer of 1996, but is primarily due to the ongoing changes in the structure of the industry. Historically, reliability has been maintained based on cooperation among similar, regulated, vertically integrated utilities voluntarily complying with policies developed by reliability organizations of their creation: the North American Electric Reliability Council (NERC) and the associated regional reliability councils.

The new industry will be characterized not by a single dominant type of company (the vertically integrated utility), but by a wide variety of companies competing in various aspects of the business; not by similarity and commonality in the interests and incentives of industry players, but by diversity; not by a small number of simple transactions, but by an increasing number of increasingly complex transactions. As a result, it is widely recognized that the old ways in which reliability was maintained must be adapted to the new circumstances, entities, transactions, and incentives. There is a need for mechanisms to ensure compliance by all entities with a minimum set of reliability "rules of the road".

In addition, given the wide variety of players in the new industry, responsibility for reliability must be unambiguous, focused and independent of the market. The ISO institution, conceived with an open access purpose, is well placed to play a key role in this important area.

1. The views expressed herein are those of the authors and do not necessarily reflect the views of the Department of Energy. 


\section{Current Progress in ISO Definition and Formation}

At the present time, there are at least ten ISOs being developed or discussed across the continental United States, covering all areas but the Southeast and small parts of the Midwest. Some are already in operation with limited functionality, while others are only in the early stages of discussion.

The ISOs are being defined in utility-led processes with guidance from FERC and, at least in the final stages of development, broad stakeholder involvement. FERC's guidance, which is continually being

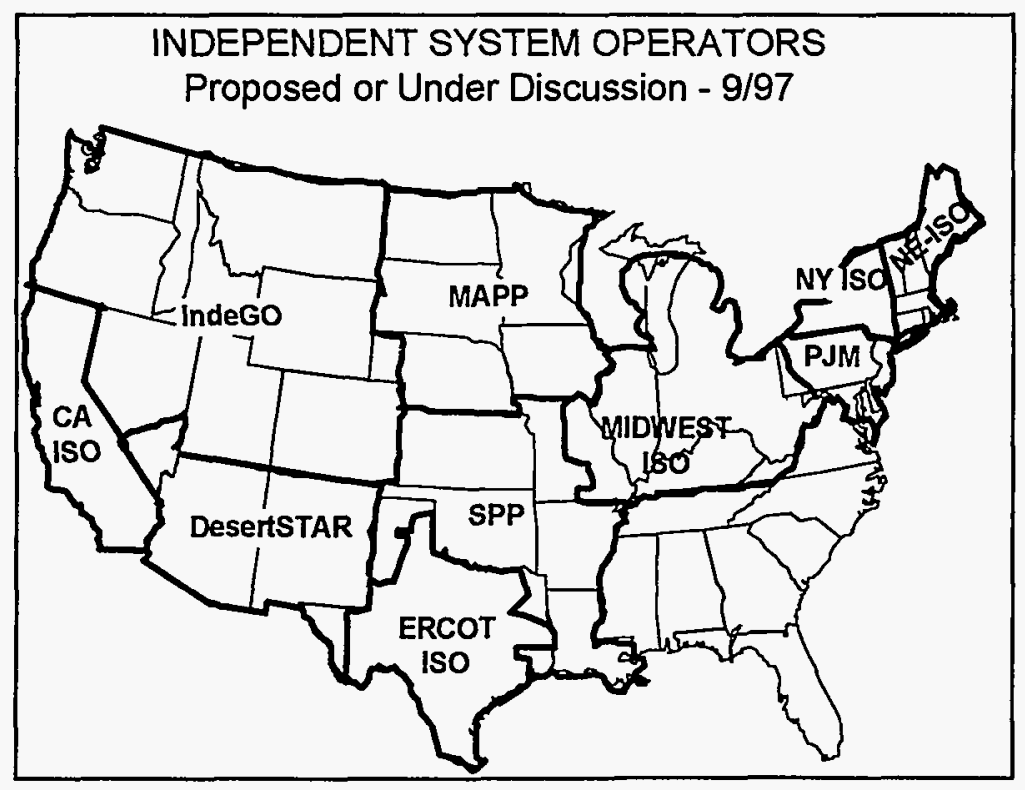
augmented through new rulings, still leaves substantial latitude for creativity and adaptation to local circumstances. In the past several months FERC has reviewed and commented in detail on proposals for California, New England, Pennsylvania, New Jersey and Maryland (PJM), and the upper Midwest, and two additional ISO proposals (IndeGO in the northwest and the Midwest ISO) are nearly completed and are expected to be filed with FERC this year. As a result, it is now becoming possible to identify the patterns emerging across these proposals - the ISO concept has crystallized to a great degree in recent months.

The first ISO to become operational was in Texas (ERCOT), which did not require FERC approval. The other ISOs that could be considered operational are PJM (operating under "interim" FERC approval), and NEPOOL ("Phase I"). Current schedules would result in six ISO proposals appearing before FERC by the end of 1997, with five ISOs going operational in some initial form by early 1998 . The time required to develop and implement ISOs has and will continue to vary widely among the various regions, from several months to several years, reflecting the complexity of the changes being contemplated, the perceived urgency of the process, and the ease with which the parties have found common ground.

\section{Emerging Characteristics of ISOs}

The ISOs can be characterized into two broad groups: ISOs with substantial authorities (NEPOOL, NYPP, and PJM, where power pools already existed, and also California), and ISOs with more limited authorities, which are generally being formed on the basis of less developed pre-existing forms of joint planning and operation. The key characteristics of most ISOs as they are currently proposed, and some of the variants, are summarized in Table E-1. 
Table E-1. Summary of Key Attributes of ISOs as Currently Proposed

\begin{tabular}{|c|c|}
\hline 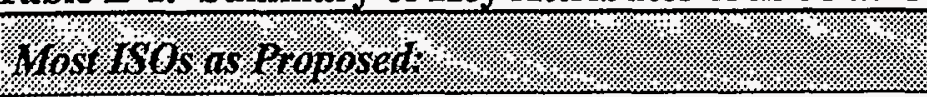 & 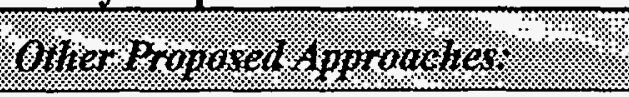 \\
\hline ISO is a new, independent, non-profit entity & $\begin{array}{l}\text { Some ISOs are related to power pools } \\
\text { and/or Regional Reliability Councils; } \\
\text { some may contract out functions to a } \\
\text { private company }\end{array}$ \\
\hline $\begin{array}{l}\text { ISO is governed by a Board of independent Directors } \\
\text { reflecting a mix of relevant experience and qualifications }\end{array}$ & $\begin{array}{l}\text { Some ISOs will have Boards of Directors } \\
\text { representing specific stakeholder groups }\end{array}$ \\
\hline $\begin{array}{l}\text { Directors must have no financial ties to the market or market } \\
\text { participants }\end{array}$ & $\begin{array}{l}\text { Some ISOs will allow directors that are } \\
\text { affiliated with interested parties }\end{array}$ \\
\hline $\begin{array}{l}\text { ISO functionally controls the high voltage transmission } \\
\text { system under contract with transmission owners }\end{array}$ & Degree of control varies \\
\hline $\begin{array}{l}\text { Region of ISO-controlled grid will operate as single control } \\
\text { area }\end{array}$ & $\begin{array}{l}\text { Some have multiple control areas } \\
\text { obligated to fulfill ISO directives }\end{array}$ \\
\hline $\begin{array}{l}\text { ISO is responsible for reliability, is NERC Security } \\
\text { Coordinator }\end{array}$ & $\begin{array}{l}\text { Some control areas retain substantial } \\
\text { responsibility }\end{array}$ \\
\hline \multicolumn{2}{|l|}{$\begin{array}{l}\text { ISO has full authority to take action in a system emergency, } \\
\text { all players are required to follow ISO directives }\end{array}$} \\
\hline $\begin{array}{l}\text { ISO complies with all applicable policies and standards of } \\
\text { NERC and the regional reliability councils }\end{array}$ & $\begin{array}{l}\text { ISO role in developing local procedures } \\
\text { and in enforcement not clear }\end{array}$ \\
\hline $\begin{array}{l}\text { ISO schedules transmission, runs OASIS calculates ATC; } \\
\text { region has a single, non-pancaked transmission tariff }\end{array}$ & $\begin{array}{l}\text { Transmission and congestion pricing } \\
\text { approaches vary }\end{array}$ \\
\hline $\begin{array}{l}\text { ISO resolves congestion, redispatching or taking other } \\
\text { actions as necessary }\end{array}$ & Degree of ISO coordination role varies. \\
\hline $\begin{array}{l}\text { ISO determines the quantities of ancillary services required, } \\
\text { and provides them, procuring most competitively }\end{array}$ & $\begin{array}{l}\text { Extent of ISO role, and degree to which } \\
\text { procurement is market-driven, varies }\end{array}$ \\
\hline $\begin{array}{l}\text { ISO is not a power exchange, is to fulfill functions with } \\
\text { minimal impact on bulk power transactions }\end{array}$ & Some ISOs are also power exchanges \\
\hline $\begin{array}{l}\text { ISO coordinates transmission maintenance scheduling, can } \\
\text { deny a schedule for reliability or efficiency reasons }\end{array}$ & Degree of ISO control varies \\
\hline $\begin{array}{l}\text { ISO plays a lead role in transmission system planning. } \\
\text { Transmission owners can be compelled to build }\end{array}$ & $\begin{array}{l}\text { ISO coordinates; cannot compel } \\
\text { construction }\end{array}$ \\
\hline
\end{tabular}

An example of an ISO with limited authorities would be ERCOT, which does not have direct control of generation (this is characteristic of several ISO proposals), does not provide ancillary services, coordinates between control areas which remain primarily responsible for reliability, and serves only a coordinating role among the utilities in transmission planning. 
ISOs with more substantial authorities such as California, NEPOOL or PJM are the sole control areas in the region, the sole providers of transmission and most ancillary services in the region, are NERC Security Coordinators with prime responsibility for regional security, and take lead roles in regional transmission planning. In addition, they either serve as power exchanges or have closely associated power exchanges.

ISOs will not own or lease transmission but instead control transmission according to transmission control agreements with the transmission owners (TOs). These fundamental contracts typically specify the precise facilities to be controlled, the TO's obligation to physically operate facilities according to ISO directives, ISO and TO responsibilities under emergency circumstances, TO maintenance responsibilities, maintenance scheduling procedures, ISO and TO responsibilities in system planning, rights and procedures for additional TOs to join the agreement, and the liabilities of the parties, among other provisions. As the TOs will not control the governance of the ISOs (typically the TOs receive $25 \%$ or fewer of the seats on the Board of Directors) it is these contracts, rather than any form of control over ISO decision-making, that protect the TOs' interests.

The facilities to be controlled by the ISO are generally defined to be those making up the transmission network or critical to bulk system security; this was considered to generally include $230 \mathrm{kV}$ and up in one instance, $60 \mathrm{kV}$ and up in another. ISOs will also have the authority to identify additional facilities that need to be under ISO control.

All of the proposed ISOs are required under their founding documents to follow NERC and Regional Reliability Council reliability operating and planning policies and procedures, and most ISOs are to serve as the NERC Security Coordinator for the grid they control. This will make the ISO responsible for:

- Next day security analysis and information sharing;

- Identification of need and selection of special operating procedures (redispatching generation, modification of interchange transactions, or transmission reconfiguration);

- Determination of a generation deficiency;

- Identifying transmission system problems, notifying other Security Coordinators, and implementing relief as needed, including redispatch or curtailment;

- Declaring system emergency and directing redispatch or curtailment; and

- Determining when the system has returned to a normal state and informing others.

ISOs will develop specific procedures for ancillary services, congestion relief, and emergency management based on NERC policies as applied to local conditions. Transmission users will be required to comply with reliability standards under either the ISO tariff or in connection or other agreements with the ISO.

ISOs will provide one-stop shopping for transmission service within the region of the ISO controlled grid, under a single, non-pancaked tariff as required by FERC. The ISO will operate the OASIS system and be responsible for calculating Available Transfer Capability (ATC). In some cases these 
responsibilities will be phased in over time. Transmission owners will also be required to schedule transmission through the ISO. Many ISOs will initially offer "zonal" transmission pricing. The ISO will also generally bill for transmission services, and collect and distribute the revenue to transmission providers.

ISOs will be responsible for identifying congestion on the system and working to relieve it, typically redispatching generation based on voluntary increment and decrement bids. In most cases the ISO's goal is narrowly defined as relieving congestion; the ISO will redispatch to maximize use of transmission but not to achieve a more efficient use of available generation resources.

The ISO will be responsible for the adequacy of ancillary services, either procuring the services competitively or contracting for them rather than owning or controlling the facilities necessary to provide them. ISOs will be responsible for determining the quantities of ancillary services required in aggregate and in support of specific transactions based on NERC standards. ISOs will also be responsible for ensuring that all transactions are supported by the required ancillary services, and can reject schedules if the required ancillary services are not available.

Most ISOs will take a lead role in a collaborative process of transmission system planning. Some proposals would essentially obligate the TOs to build projects identified through the ISO planning process, while others call for "best efforts" or "due diligence". As only the TOs possess eminent domain authority, ISOs and potential third party project sponsors will be dependent upon the TOs for siting and other approvals. Some ISO proposals set a goal of obtaining eminent domain authority for the ISO.

\section{Issues and Questions About the Formation of ISOs}

The review of ISO proposals included in this report has identified a number of issues about ISO attributes and how they will fulfill their various functions and responsibilities. Some of the following issues are of concern to only a few of the proposed ISOs, while others pertain to the fundamental concept of an ISO.

Will the fundamental concept of an ISO - as a controller, but not owner, of transmission - work well? This relationship clearly raises coordination and incentive issues in many areas of ISO operation. The split of ownership and control needs to work well to result in effective operation and maintenance, including under emergency circumstances, and control over costs and market power. This relationship is further complicated where there will be multiple control areas.

2. Under zonal transmission pricing, transmission access charges are uniform within geographic zones, and are assessed based on the location of the load being served. As a consequence, the charge to be paid for transmission to serve a particular load is independent of the location of the supplying generation within the ISO-controlled grid. The zones typically correspond to current utility service territories. Inter-zonal congestion charges are separate. 
Will non-discriminatory transmission access be accomplished? It may be difficult for ISOs with limited authority to ensure non-discriminatory transmission access. ISOs need sufficient control over transmission to prevent TOs from creating subtle barriers to generators that would compete with their affiliates.

How flexible will ISO boundaries be if they need to change? Larger ISOs could be more effective in terms of transmission scheduling, system operation, and security, and more convenient for transmission users. Larger ISOs could form from smaller ISOs by ISOs combining, or transmission owners withdrawing from one ISO and joining another, or an ISO dissolving and the member transmission owners joining one or more other ISOs.

How should ISOs be governed to be effective? A governance structure that includes both independent directors and representatives of particular interest groups could be appropriate. Boards made up of representatives of narrow stakeholder groups could be characterized by stalemate and inability to act, as such directors would be expected to vote according to their constituencies' narrow interests. This could make it difficult to address issues that will be identified in ISO structure and procedures as they gain operating experience. Where ISOs will have governing boards made up of independent directors, directors may be so independent as to be detached or uninformed of the issues.

How will ISOs adapt and evolve to effectively fulfill their functions? Care should be taken to ensure that ISO procedures do not make it overly difficult to change the ISO founding documents or ISO procedures. The desire of the parties involved in designing the ISO to ensure that the many negotiated compromises will not be substantially changed is understandable. ISOs, as newly-invented institutions, need flexibility to evolve and adapt to best fill their roles, without which it could be difficult to make adjustments as they gain operating experience. Inflexible ISO rules and processes could also result in the ISO, and ultimately FERC, facing larger numbers of ISO-related disputes, as rules problems go unfixed and provide cause for grievance.

How will incentives or sanctions be applied to a non-profit ISO? The ISO has no owners or profits. While some incentives for officers and employees could potentially be defined, these could be hard to relate to the ISO's broader objectives. Sanctions would likely end up being passed on to transmission users either directly or indirectly.

How will liability issues be addressed? Should a non-profit ISO with few assets be found liable for damages, who will pay? Insurance will cover all or part of damages in many instances (the insurance premiums are of course paid by transmission users through tariffs as an operating expense), but any costs not covered by insurance would ultimately land on TOs or transmission users.

How will ISOs achieve an appropriate balance between commercial and reliability objectives? These objectives intersect in transmission scheduling, congestion relief, ancillary services procurement, line loading relief, curtailment, and other areas of ISO responsibility. These procedures will be developed and modified within the ISO based on NERC and Regional Reliability Council 
(RRC) standards. In the process, ISOs must strike a balance between reliability, efficiency, fairness, confidentiality of information, and other objectives.

How will ISOs enforce reliability compliance? The extent of ISO responsibility for monitoring and enforcement of the reliability compliance of transmission users is not yet clear. Nor is it clear to what extent ISOs will establish sanctions and develop or tailor monitoring and enforcement procedures, adapted to local conditions, or whether these procedures will be imposed on the ISO from NERC/RRC. Even if largely imposed on the ISO, there will undoubtedly be some flexibility in how these procedures are applied. This could result in conflicts, especially if various stakeholders, the ISO, and the reliability organizations have different views about balancing reliability and commercial values. Reliability rules must not be perceived as being enforced in a way that allows market power to be exercised.

How will the ISOs work together with the Regional Reliability Councils? The relative roles of these two entities and their relationship is not clear in most ISO proposals. In some areas, the ISO and RRC geographic boundaries may not coincide (for instance, the Midwest ISO). Coordination and clear delineation of responsibilities is needed.

How will ISOs lead effective regional transmission planning? The planning process will be most effective where ISOs have strong roles in transmission planning but it is doubtful that ISOs will be any more effective in overcoming the many obstacles that exist today to transmission system expansion. If the TOs remain in control of some of the key steps in transmission planning such as retaining responsibility for acquiring regulatory approval for new facilities, questions may be raised about whether open access is being achieved.

How will ISOs resolve transmission congestion? ISO authority and access to information needs to be sufficient to resolve congestion situations. There is also the broader issue of providing the ISO with sufficient motivation to squeeze the most it can out of scarce transmission.

How will the separation of transmission operation from market operation affect efficiency? Some ISO proposals will allow multiple power exchanges and bilateral contracts, relying on the ISO to bring these various schedules together and identify and resolve congestion situations. An alternative approach used in some foreign markets is to require mandatory pools. It is too soon to tell what approach will result in the most open, flexible, and efficient power markets.

What are the alternatives to ISOs? While most of the current focus is on ISOs, some suggest that there will ultimately be a transition to regulated, for-profit Transcos that combine system operation and transmission ownership. 


\section{Potential Policy Options for ISOs and Bulk Power System Reliability}

Policy options and additional guidance on the formation of ISOs that might contribute to favorable resolution of some of the issues raised above include the following: ${ }^{3}$

- The role of FERC in enabling enforcement of compliance with reliability-related provisions could be increased. FERC can do this now, but enforcement could potentially be successfully challenged without some legislative support. Before taking such a step, FERC would undoubtedly have to review and approve NERC and RRC governance and processes to ensure that their work involves sufficient input from interested parties, is non-discriminatory and in the public interest. Additional FERC authority would also be required to impose reliability compliance on non-jurisdictional entities, specifically municipals, cooperatives, Power Marketing Administrations, and TVA.

- Efforts underway by NERC, DOE, and other parties could clarify the future reliability management organizational framework and the role of ISOs in it.

- The Department of Energy's statutory role in monitoring and reporting on reliability issues could be strengthened, especially during the transitional period when roles are changing. This monitoring and reporting role would be a natural complement to FERC's existing and potentially larger role in reliability enforcement.

- $\quad$ Additional FERC guidance on ISOs, perhaps in the form of a policy statement, could address other issues that have an impact on the effectiveness of ISOs, such as ISO formation and governance, barriers to evolving the ISO and its procedures, barriers to formation of larger ISOs, etc.

- Policies that support broader geographic planning processes and the implementation of needed transmission system modifications could be pursued. The formation of regional regulatory agencies to correspond to the geographical scope of ISOs, with authority delegated from state and federal authorities, could streamline the process for gaining necessary approvals for system enhancements.

- Legislation to resolve liability issues in some states or at the federal level could eliminate this potential barrier to changes in the industry and formation of effective ISOs.

- Since information access and confidentiality issues have and will likely continue to be contentious, regulatory and/or legislative actions could support requirements to provide information, and assurances of confidentiality. FERC could take a more active role in the implementation of OASIS systems across the U.S.

3. These policy options do not necessarily reflect the position of the Department of Energy. 


\section{Background: Maintaining Bulk Power System Reliability in a Restructured, More Competitive Electric Power Industry: Issues and Initiatives}

This section provides background on reliability related institutions in the regulated industry and some of the present thinking about the changes that could be made to institutions for reliability management in a restructured industry.

Historically, vertically integrated electric utilities bore primary responsibility for maintaining bulk power system reliability. The utilities created and were the members of voluntary industry organizations for working out reliability policies and standards. The utilities funded and controlled the Regional Reliability Councils (RRCs) of which there are currently ten. The RRCs in turn are the primary members of the North American Electric Reliability Council (NERC), the central and lead industry body for reliability policy and standards. Government involvement in the reliability management process has generally been limited to a minor oversight role. Government also approved recovery of the reliability-related costs from consumers.

Under the regulated regime, the allocation of reliability-related costs was not very important. As utilities were vertically integrated, it was not necessary to allocate costs between generation, transmission, and distribution. Nor was it always important to identify causes and allocate costs in the case of an outage and resulting damage. Among utilities participating in the Western Interconnected Systems, for instance, the utilities had a no-fault insurance arrangement, which called for each utility to resolve any liability claims with its own customers regardless of whether in fact the customer suffered due to an outage for which a different utility was actually at fault. Under the regulated regime, utilities voluntarily adopted measures to maintain reliability, both in real time and in longer term time frames.

As the industry restructures, new types of entities, transactions, relationships and incentives will be created:

- Some utilities will likely functionally disaggregate into generation, transmission and distribution companies. Transmission and distribution will remain regulated, while generation will become deregulated and operate under profit motives in a competitive market. New competitive merchant plants will be built.

- Load serving entities will sign up customers and procure power to meet these loads. Brokers, marketers, aggregators, and others will participate in wholesale and retail electricity markets. Consumers will face a range of options for their electricity supply, including long-term and short-term deals. 
- Power exchanges will be established to operate auctions for short-term energy and to interface with system operators for longer term transactions.

- System operation will be established as a separate, independent function, to ensure that power markets are operated in a non-discriminatory manner.

Generators, load-serving entities, aggregators, and marketers will all operate under competitive circumstances and be primarily profit-motivated. They will be seeking ways to reduce the cost of their products and be more competitive, and in particular will be very concerned that they are paying only their fair share of system costs, including reliability-related costs. Market-based institutions will be developed for energy, capacity, ancillary services, and congestion resolution. In designing these institutions, trade-offs between fairness, efficiency, complexity, reliability and other objectives will be faced.

\subsection{Reliability Issues}

The new entities, transactions, relationships and incentives raise issues regarding the institutional frameworks that will maintain reliability in the future. Specifically, the following issues have been raised:

- How will independent, commercially-oriented generators be motivated to take actions that contribute to bulk system reliability?

- What incentives will motivate investors to build new generating capacity in a timely manner?

- What mechanisms will ensure that suppliers always arrange to meet the level of reliability (firmness) that they have committed to customers?

- How will the growing number of increasingly complex transactions affect the ability of system operators to maintain reliability?

- What new mechanisms will be used to provide unbundled ancillary services?

- How will accountability for reliability be assigned, especially in the transition, as new entities are created and assume various types and degrees of responsibility?

- How will independent system operators balance the pressures to maximize commercial use of the grid with the maintenance of reliability?

- How will new regulatory arrangements, such as performance-based regulation, provide incentives for actions by transmission owners or system operators to maintain reliability? 
- What mechanisms can ensure that industry participants share the information and coordinate operations necessary for maintaining reliability?

Recognition of these issues has resulted in initiatives to develop recommendations for ensuring bulk power system reliability, including the Secretary of Energy's Task Force on Bulk System Reliability; an EEI CEO Task Force; and a NERC Blue Ribbon panel.

The focus of this paper is bulk system (rather than distribution system) reliability, and on the role of the system operator in reliability. Bulk system reliability is typically further subdivided into two components, adequacy and security; adequacy pertains to the ability of the system to provide expected services, and security pertains to whether the system can withstand equipment failures and other problems. Adequacy of generation will be largely left to the market, perhaps with some additional incentive mechanisms or reserve requirements, especially during a transitional period. The primary concerns about the bulk power system pertain to security, which is the focus of this report.

Most of the potential reliability issues listed above can be successfully addressed using market and contractual approaches, if the transition is pursued with adequate time and preparations. There is a recognized need, however, for additional authority for these mechanisms to be implemented and work.

The new industry will comprise three types of entities, with corresponding incentives:

1. Competing, profit-motivated entities (generators, marketers, brokers, load-serving entities, investors): These entities will respond to market incentives and observe industry standards to provide reliability services and to conduct operations in a way that will not threaten system reliability. Currently, market incentives are not aligned well with reliability needs. Recognizing the effects that transactions conducted by these entities have on reliability and providing appropriate market signals for those effects will help maintain reliability. Tariffs and connection agreements could be used to clarify the responsibilities of these entities.

2. Regulated, profit-motivated entities (transmission owners, distribution companies): These entities will receive a regulated return on operations and investments. Performance-based regulation could provide increased incentives for efficient and reliable operations.

3. Regulated, non-profit entities (most or all Independent System Operators): Reliability performance will be a primary focus of these organizations. Providing effective incentives for such performance within a non-profit organization may be a significant challenge.

Table 1-1 summarizes the requirements of each entity to maintain bulk system reliability and how these requirements are likely to be accomplished in the restructured industry. 
Table 1-1: Ensuring Bulk Power System Reliability: Requirements and Mechanisms

\begin{tabular}{|c|c|c|c|}
\hline Entity & $\begin{array}{l}\text { What is Needed From This } \\
\text { Entity to Maintain Bulk } \\
\text { System Reliability? }\end{array}$ & $\begin{array}{l}\text { What Mechanisms } \\
\text { Can be Used to } \\
\text { Maintain Reliability? }\end{array}$ & $\begin{array}{l}\text { What New Policies } \\
\text { Can be Used to Make } \\
\text { the Mechanism Work? }\end{array}$ \\
\hline \multirow[t]{8}{*}{ Generators } & Reliable performance, availability & Market incentives & None \\
\hline & Provide ancillary services & Market incentives & None \\
\hline & $\begin{array}{l}\text { Schedule maintenance so as to not } \\
\text { threaten system reliability }\end{array}$ & $\begin{array}{l}\text { Primarily market } \\
\text { incentives }\end{array}$ & None \\
\hline & $\begin{array}{l}\text { Generate (quantity, timing) } \\
\text { according to system operator's final } \\
\text { determination }\end{array}$ & $\begin{array}{l}\text { Market incentives, } \\
\text { contractual requirement } \\
\text { for connection }\end{array}$ & $\begin{array}{l}\text { Provide system operators } \\
\text { with clear authority to } \\
\text { impose and enforce such } \\
\text { requirements }\end{array}$ \\
\hline & $\begin{array}{l}\text { Follow system operator's directives } \\
\text { under potential emergency } \\
\text { circumstances }\end{array}$ & $\begin{array}{l}\text { Contractual requirement } \\
\text { for connection }\end{array}$ & $\begin{array}{l}\text { Provide system operators } \\
\text { with clear authority to } \\
\text { impose and enforce such } \\
\text { requirements }\end{array}$ \\
\hline & $\begin{array}{l}\text { Observe NERC requirements } \\
\text { regarding governors, etc. }\end{array}$ & $\begin{array}{l}\text { Contractual requirement } \\
\text { for connection }\end{array}$ & $\begin{array}{l}\text { Provide system operators } \\
\text { with clear authority to } \\
\text { impose and enforce such } \\
\text { requirements }\end{array}$ \\
\hline & $\begin{array}{l}\text { Pay their share of reliability-related } \\
\text { costs (either directly incurred or } \\
\text { levied as fees) }\end{array}$ & $\begin{array}{l}\text { Contractual requirement } \\
\text { for connection }\end{array}$ & $\begin{array}{l}\text { Provide system operators } \\
\text { with clear authority to } \\
\text { impose and enforce such } \\
\text { requirements }\end{array}$ \\
\hline & $\begin{array}{l}\text { Provide information needed for } \\
\text { reliable system operation and } \\
\text { planning }\end{array}$ & $\begin{array}{l}\text { Contractual requirement } \\
\text { for connection }\end{array}$ & $\begin{array}{l}\text { Provide system operators } \\
\text { with clear authority to } \\
\text { impose and enforce such } \\
\text { requirements }\end{array}$ \\
\hline Investors & $\begin{array}{l}\text { Finance new or rebuilt generation } \\
\text { and transmission capacity when and } \\
\text { where required }\end{array}$ & Market incentives & $\begin{array}{l}\text { None (capacity reserve } \\
\text { req'ts may provide } \\
\text { additional incentive) }\end{array}$ \\
\hline \multirow{2}{*}{$\begin{array}{l}\text { Marketers, } \\
\text { Brokers, } \\
\text { Load Serving } \\
\text { Entities, } \\
\text { Power } \\
\text { Exchanges }\end{array}$} & $\begin{array}{l}\text { Provide transaction information to } \\
\text { ISO required for reliable system } \\
\text { operation and planning }\end{array}$ & $\begin{array}{l}\text { Contractual requirement } \\
\text { for market operations }\end{array}$ & $\begin{array}{l}\text { Provide system operators } \\
\text { with clear authority to } \\
\text { impose and enforce such } \\
\text { requirements }\end{array}$ \\
\hline & $\begin{array}{l}\text { Maintain proper balance of loads } \\
\text { and supplies, ability to meet } \\
\text { commitments to loads (firmness) }\end{array}$ & $\begin{array}{l}\text { Market incentives, } \\
\text { consumer protection and } \\
\text { disclosure rules }\end{array}$ & $\begin{array}{l}\text { States would implement } \\
\text { consumer protections }\end{array}$ \\
\hline
\end{tabular}




\begin{tabular}{|c|c|c|c|}
\hline 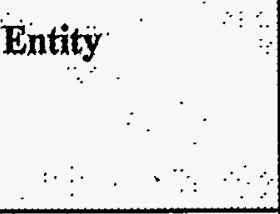 & $\begin{array}{l}\text { What is Needed From This } \\
\text { Entity to Maintain Bulk } \\
\text { System Reliability? }\end{array}$ & $\begin{array}{l}\text { What Mechanisms } \\
\text { Can be Used to } \\
\text { Maintain Reliability? }\end{array}$ & $\begin{array}{l}\text { What New Policies } \\
\text { Can be Used to Make } \\
\text { the Mechanism Work? }\end{array}$ \\
\hline \multirow{5}{*}{$\begin{array}{l}\text { Transmission } \\
\text { Owners, } \\
\text { ISO- } \\
\text { Subordinate } \\
\text { Control Areas }\end{array}$} & $\begin{array}{l}\text { Provide reliable transmission } \\
\text { service, perform adequate } \\
\text { transmission system maintenance } \\
\text { according to NERC, RRC, ISO }\end{array}$ & $\begin{array}{l}\text { Regulatory incentives, } \\
\text { transmission control } \\
\text { agreement w/ISO }\end{array}$ & \multirow[t]{5}{*}{$\begin{array}{l}\text { None (Transmission } \\
\text { owners voluntarily enter } \\
\text { into transmission control } \\
\text { agreements with ISOs) }\end{array}$} \\
\hline & $\begin{array}{l}\text { Follow system operator's directives } \\
\text { under normal and emergency } \\
\text { circumstances }\end{array}$ & $\begin{array}{l}\text { Transmission control } \\
\text { agreement w/SO }\end{array}$ & \\
\hline & $\begin{array}{l}\text { Coordinate transmission } \\
\text { maintenance scheduling w/ISO }\end{array}$ & $\begin{array}{l}\text { Transmission control } \\
\text { agreement w/ISO }\end{array}$ & \\
\hline & $\begin{array}{l}\text { Support planning, siting and } \\
\text { approval of system modifications }\end{array}$ & $\begin{array}{l}\text { Transmission control } \\
\text { agreement w/ISO }\end{array}$ & \\
\hline & $\begin{array}{l}\text { Enhance the transmission system } \\
\text { according to requirements } \\
\text { determined in the regional planning } \\
\text { process }\end{array}$ & $\begin{array}{l}\text { Regulatory incentives, } \\
\text { transmission control } \\
\text { agreement w/ISO }\end{array}$ & \\
\hline \multirow{5}{*}{$\begin{array}{l}\text { System } \\
\text { Operators } \\
\text { (ISOs), as } \\
\text { transmission } \\
\text { schedulers, } \\
\text { Security } \\
\text { Coordinators }\end{array}$} & $\begin{array}{l}\text { Operate the system in a reliable } \\
\text { manner according to NERC, RRC }\end{array}$ & \multirow{5}{*}{$\begin{array}{l}\text { Functions are required by } \\
\text { FERC, agreements with } \\
\text { Transmission Owners, } \\
\text { ISO Bylaws, etc. } \\
\text { including compliance } \\
\text { with NERC standards; no } \\
\text { particular incentives in } \\
\text { most instances. }\end{array}$} & \multirow{5}{*}{$\begin{array}{l}\text { Provide clear authority to } \\
\text { impose and enforce such } \\
\text { requirements }\end{array}$} \\
\hline & $\begin{array}{l}\text { Procure adequate ancillary services } \\
\text { for reliable operations }\end{array}$ & & \\
\hline & $\begin{array}{l}\text { Monitor market participants for } \\
\text { reliability compliance }\end{array}$ & & \\
\hline & Plan for future reliable operations & & \\
\hline & $\begin{array}{l}\text { Coordinate with other Security } \\
\text { Coordinators: provide information, } \\
\text { take actions as required }\end{array}$ & & \\
\hline $\begin{array}{l}\text { Distribution } \\
\text { companies }\end{array}$ & $\begin{array}{l}\text { Coordinate physical system } \\
\text { operation, maintenance and } \\
\text { enhancements with transmission } \\
\text { owners, ISO }\end{array}$ & $\begin{array}{l}\text { Regulatory requirements, } \\
\text { regulatory incentives }\end{array}$ & $\begin{array}{l}\text { Provide system operators } \\
\text { with clear authority to } \\
\text { impose and enforce such } \\
\text { requirements }\end{array}$ \\
\hline
\end{tabular}




\subsection{Possible Organizational Framework for Reliability Management in a Restructured Industry}

While discussion continues regarding whether competition will contribute to or jeopardize reliability, the extent to which markets can be relied upon to provide reliability, the roles of FERC, NERC and the regional reliability councils (RRCs) in reliability, and other issues, there are also many issues around which consensus does seem to be emerging:

- All market participants have an interest in bulk system reliability. However there are different views regarding how much of a problem reliability may become and how reliability should be maintained.

- As the industry undergoes restructuring, responsibility for bulk system reliability management should be clearly assigned and focused. System operators that are independent of the commercial market to protect against discriminatory exercise of their authority can best fulfill this responsibility.

- Reliability standards should continue to be worked out by industry experts and industry organizations, not by government. NERC and the RRCs adapted for the new industry circumstances, or successor organizations, can provide the necessary expertise.

- More formal mechanisms will be required for ensuring compliance with reliability standards, including authority to enforce standards and levy penalties. Enforceability will require that standards be more specific and measurable.

- Making reliability standards enforceable will require federal oversight of the industry reliability organization. FERC can best fulfill this responsibility.

- In order for reliability standards to be generally accepted and complied with by industry entities, the governance and decision processes of the reliability organizations should reflect all relevant interests and should not be dominated by any particular industry group.

- In developing mechanisms for ensuring reliability compliance, the viability and vigor of the commercial market must not be unnecessarily restricted.

- The costs of maintaining reliability should be a factor in determining the level of reliability and those costs should be equitably distributed.

However, many details on how these changes will be accomplished are not yet agreed.

- How should FERC provide a legal basis for reliability enforcement? 
- FERC could potentially require that all jurisdictional entities comply with NERC and RRC policies and standards; this could require new legal authority. Before taking this step, FERC would have to approve NERC and RRC organization, governance, processes, etc. Legal limitations to delegation of authority would apply and restrict the extent to which this approach could be taken.

- Another alternative would be for FERC to take a lead role in the process of development of reliability rules and standards, and in their enforcement. This would require a significant expansion of FERC's authority and capabilities.

- An intermediate approach, modeled on the self-regulation of the U.S. securities industry, could provide FERC with authority to review and approve or reject reliability standards and specific instances of enforcement. FERC could play an oversight role and allow the industry organizations to have the primary role.

- What specific mechanisms will be used to implement reliability standards for specific entities? For transmission owners and users, the ISO could impose FERC-approved standards. ISO compliance could be required under transmission control agreements or other documents that form the ISO (bylaws, etc.)

- How would FERC ensure reliability compliance by entities over which it does not currently have jurisdiction, specifically municipals, cooperatives, Power Marketing Administrations, and TVA? Legislation could make reliability rules applicable to such entities.

- Is there a need for Independent Interconnection Operators (IIO) to provide security functions as proposed by NERC, and if so, what would be their relationship to the ISOs? Such an entity could augment horizontal coordination among Security Coordinators and provide a single point of responsibility for the interconnection.

- What entities will be responsible to monitor and enforce compliance with reliability policies? A twolevel approach may make the most sense, wherein NERC and the RRCs hold control areas responsible for reliability compliance, and control areas monitor and enforce reliability compliance of transmission owners and users. This twolevel approach corresponds

Obligations (from the Introduction to the NERC Operating Policies)

NERC Operating Policies place the responsibility for operating reliably primarily on the CONTROL AREAS that operate within the four Interconnections of the United States and Canada and northern Baja California Norte, Mexico.

NERC recognizes that in the open access transmission environment, CONTROL AREAS are assigning some of their responsibilities, especially for transmission security, to other entities. These entities include Independent System Operators, and SECURITY COORDINATORS. The CONTROL AREAS who assign responsibilities to other entities must ensure those entities comply with the NERC Operating Policies.

Purchasing-Selling Entities are also responsible for fulfilling their informational and procedural obligations, and to keep records that document this compliance. 
to the present system (see box at right). As ISOs are formed, they will take on the current responsibilities of control areas. ISOs could delegate some or all of the monitoring, determination of an infringement, and penalty determination to the RRC or another body. Monitoring would likely also be provided by NERC and the RRCs, the transmission owners, and other market participants in their own interest: FERC would provide oversight for enforcement.

- How much latitude should ISOs have in determining and adapting reliability rules and standards, and in deciding how diligently to monitor and enforce them? While it is not always easy to determine which actions are unlikely to have impacts on the broader interconnection, a case could be made that the ISO could be allowed broad authority over these actions. Regarding impacts that could extend beyond the ISO's region, a case could be made for consistent enforcement and compliance by ISOs and all market participants.

- How can states have an effective role in ensuring bulk system reliability in the short- and longer-term? States now have authority over siting and environmental compliance, so their involvement in planning is essential. The formation of regional regulatory agencies to correspond to the geographical scope of ISOs, with authorities delegated from state and federal authorities, could streamline the process for gaining clearance for system enhancements. At the same time, it could become an impediment to the formation of larger ISOs.

- As ISOs are established with authority for system operation, planning, and reliability, what will be the roles of the RRCs, and what will be their relationship to ISOs and to NERC? RRC responsibility may also be reduced as the development of enforceable standards becomes increasingly centralized under NERC.

- What will the governance of the RRCs and NERC be as they are adapted to the new industry structure; which types of entities will get how many "votes"? Some have already changed their governance so that no one group dominates.

\subsection{Current Reliability Initiatives}

While many of the policy issues around reliability are still undecided, NERC and the regional reliability councils have a number of initiatives underway for adapting and strengthening current practices for the changing industry. EPRI and the utilities are also actively working toward this common goal. While a review of these extensive work efforts is beyond the scope of this paper, it is instructive to briefly note NERC's efforts because they are particularly relevant to the evolution of the potential role of ISOs in ensuring reliability.

The next major section of this report will describe the initiatives underway around the country to develop ISO proposals. These efforts address the full range of issues involved in defining the roles and responsibilities of ISOs. Since ISOs as system operators and control areas will be responsible 
for complying with and enforcing the standards and procedures developed by NERC and the regional councils, the NERC-led efforts amount to additional definition of the responsibilities of ISOs in reliability.

\subsubsection{Current NERC Initiatives}

At the present time NERC is in the process of modifying its standards and procedures to take into account the changes in the industry. NERC's processes for developing standards have also been changed somewhat to reflect the new industry reality, and now permit expanded participation by nonutility parties such as power marketers and end users.

Changes particularly relevant to ISOs include definition of the Security Coordinator function and Security Process Support System, and changes to operating and planning policies.

Recognizing that the changes in the industry and the implementation of ISOs will result in new types of entities with new reliability responsibilities, NERC has undertaken to define the Security Coordinator role to provide focused responsibility for reliability management. Security Coordinator procedures include the following:

\section{A. Next Day Operations Planning Process:}

This involves security analysis for the next day, including studies and analysis, information sharing with other Security Coordinators, and identification of special operating procedures if needed, which could include redispatching generation, modification of interchange transactions, or transmission reconfiguration.

B. Current Day Operations - Generation: Determine whether there is an actual or potential generation deficiency, alert all other Security Coordinators if there is.

C. Current Day Operations - Transmission: Identify problems, notify other Security Coordinators, implement relief as needed. The Security Coordinator can select between local (regional, subregional, interregional) or NERC transmission loading relief procedures. If the Security Coordinator experiencing the problem selects NERC procedures, all Security Coordinators must comply to relieve the constraint unless agreed to by the Security Coordinator who initiated the procedure. The NERC procedure calls for transactions to be curtailed on a proportional basis. If a critical situation occurs, the Security Coordinator can direct subordinate control areas to redispatch generation or reduce load to return the system to a reliable state.

In most ISO proposals, the ISO would be the Security Coordinator for the ISO-controlled grid. 
Another key element of the reliability management system will be the Security Process Support System, which includes:

- Transmission Reservation and Scheduling process, to facilitate the reliable reservation and scheduling of transmission by transmission customers;

- A Transaction Information System, providing for "tagging" of all interchange transactions with source, intermediary entities, and destination information; and

- Interchange Distribution Calculator, a tool to determine which transactions are contributing to the congestion of critical transmission facilities.

Clearly all of these systems have some commercial significance and will intersect to some extent with the procedures to be developed within the ISO. Tagging, in particular, has been controversial with some market participants. Its recent introduction has met with some opposition.

Moving from a voluntary system to mandatory reliability policies, requirements and criteria requires that they be made more precise and measurable. NERC is currently reviewing and updating its Operating Policies (summarized in the box at right) with this in mind. Changes are also required to adapt to the various problems identified above (greater numbers of transactions, more complex transactions, new players, increased commercial significance of transactions, etc.).

NERC has recently completed and issued, for the first time, NERC Planning Standards (summarized at right). In the past, planning policies have always taken the weaker form of procedures, principles and guides.

It should be noted that at the present time many of the operating and planning standards are defined only in broad or flexible terms, and allow
NERC Operating Policies 1-5 - Summary of Scope

Policy 1 Generation control and performance - operating reserve, AGC, frequency response and bias, time response, area control performance standard, inadvertent interchange, monitoring. Policy 2 Transmission - transmission security policies and coordination, voltage and reactive control, compliance reviews. Policy 3 Interchange - purchasing-selling entities responsibilities for arranging transactions (notification of control areas; transmission services; IOS); control area responsibility to approve; submission times, ramp times and durations, energy profile modification.

Policy 4 System coordination - monitoring, coordination under normal circumstances, operation security information, maintenance coordination, system protection coordination.

Policy 5 Emergency operations - coordination, procedures for insufficient generation, transmission overload, operating security limit violations (transmission system relief), separation from the interconnection, system restoration, disturbance reporting.

NERC Planning Standards - Summary of Scope

I. System Adequacy and Security

- system planning for defined contingencies

- reliability assessment

- facility connection requirements, inspection

- voltage support, reactive power

- transfer capability

- disturbance monitoring

II. System Modeling Data Requirements

III. System Protection and Control

- transmission and generation control and protection

- underfrequency or undervoltage load shedding

- special protection systems

IV. System Restoration Procedures, blackstart capability 
control area operators considerable flexibility in determining the precise procedures to follow for local conditions.

Other NERC initiatives particularly relevant to transmission system operation include work on OASIS, Available Transfer Capability, Interregional Security Network, ancillary services, commercial practices, and system operator training and certification.

\subsubsection{The WSCC Mandatory Reliability Management System}

In addition to the activities at the national level, there is activity within the regional reliability councils to provide for reliability in the restructured industry. While this topic is also outside of the scope of this paper, the efforts within the Western Systems Coordinating Council (WSCC) to develop a Mandatory Reliability Management System (MRMS) are worth noting. The MRMS follows the adoption by WSCC in November, 1996 of the "WSCC Reliability Compact for the Western Interconnected System in a Competitive Marketplace".

The WSCC MRMS involves:

- Identification of the reliability criteria most critical to reliability. 18 criteria were identified that should be made mandatory, which fall into the following five areas:

1. Generation control and performance: Reserves, frequency, generator droop, voltage;

2. Transmission system performance: Ratings, reactive margins, protective relaying, grid availability;

3. Management of unplanned events: Availability and performance of special systems (i.e., underfrequency, etc.);

4. Operator proficiency: Certification; and

5. Information exchange: Scheduling, data.

- Definition of a tiered approach to sanctions, from a minor or first time offense at Level 1 , to persistent or flagrant violations at Level 4. A specific sanction is defined for each criteria and level, increasing from letter notifications to financial penalties.

- A mechanism for making the selected high priority criteria mandatory based on existing FERC authority and contracts that WSCC members and others would enter into voluntarily. Two types of contracts are envisioned:

- one between WSCC and control area operators

- interconnection agreements or tariffs which apply to transmission users.

- A Reliability Compliance Committee with balanced representation of interested parties including transmission owners, transmission dependent utilities, IPPs, marketers, large and small customer representatives, and control area operators. The Committee would be responsible for administering the higher level sanctions and addressing stakeholder and public 
accountability issues. There would also be an appeal process and alternate dispute resolution (ADR). WSCC, however, would continue to be responsible for determining which criteria are to be mandatory, establishing sanctions, and appointing the Reliability Compliance Committee.

- A phased implementation plan, involving pilot periods in which sanctions are computed but not imposed.

The process by which incentives and sanctions could be applied is summarized in the attached detailed flow chart, which is from the draft WSCC MRMS documents.

The WSCC group acknowledged various problems with the proposed approach. The monetary sanctions may not be legally sustainable, as they are not related to damages for breach of contract and do not bear any relation to actual harm.

Concern was also expressed that the existing WSCC governing structure does not allow adequate participation by consumer groups to be able to garner the broad stakeholder and policy support that would be needed to make the MRMS work, and that the WSCC governance will have to be changed accordingly. 


\section{WSCC Incentives and Sanctions Process Flow Chart}

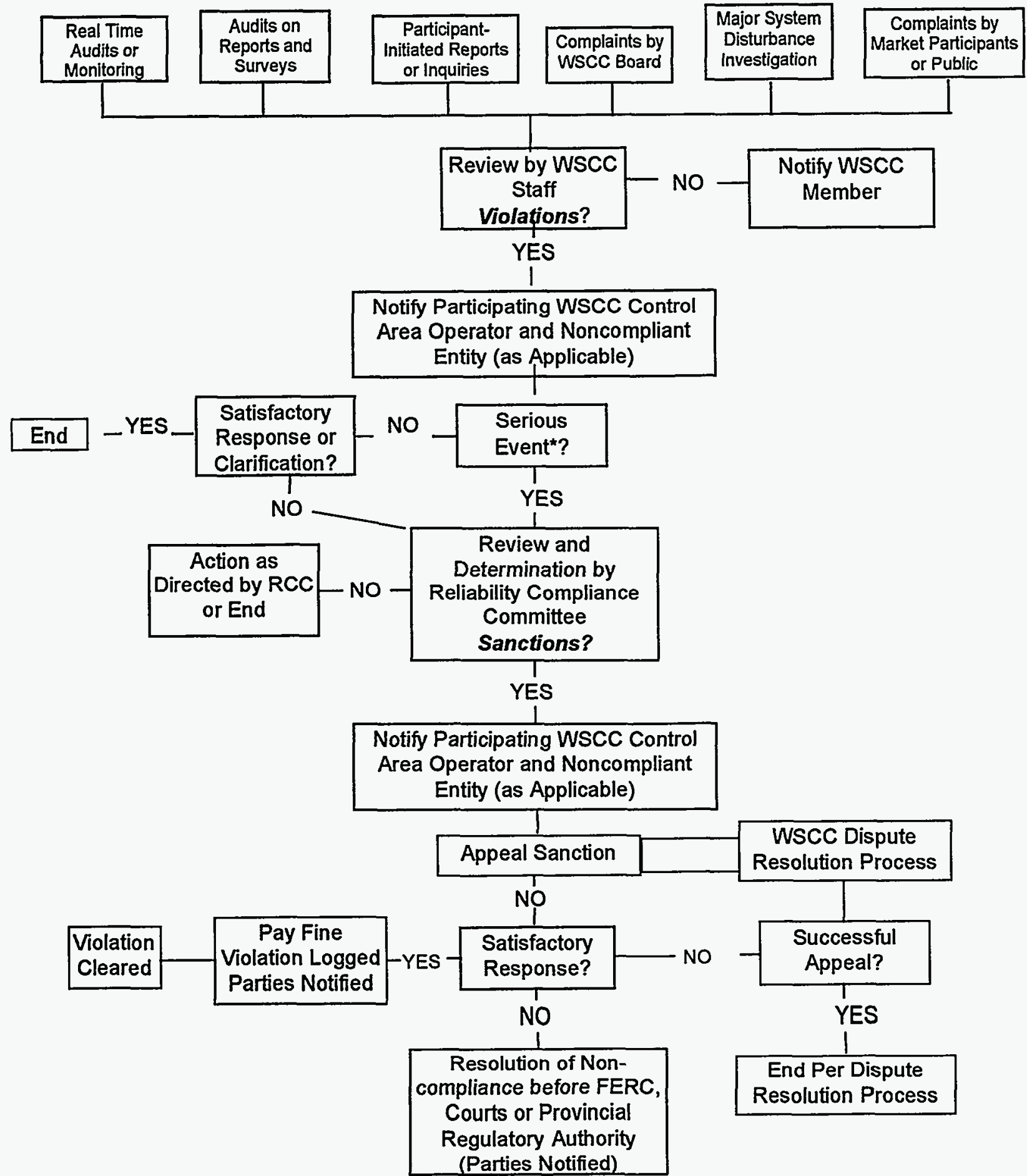

* Serious Event: Four levels of violations are identified. A level four violation has the greatest adverse impact on reliability; a level one violation has the least adverse impact on reliability. A serious event is: (i) any documented violation greater than level two; the third (or greater) occurrence of any level one violation; or (iii) the second (or greater) occurrence of any level two violation. 


\section{Overview and Comparison of ISOs Underway and Proposed}

This section gives a broad-ranging review of how various regions of the U.S. are proposing to create ISOs. Additional details on U.S. and international ISOs are in appendices.

\subsection{Bulk Power Competition, Non-discriminatory Transmission Access, and the ISO Concept}

One of the key goals of Energy Policy Act (EPAct) of 1992 was to promote greater competition in bulk power markets by encouraging entry into the generation business. A major potential barrier to entry would be limited or discriminatory access to the transmission system, and EPAct addressed this by expanding FERC's authority under sections 211 and 212 of the Federal Power Act to approve applications for transmission services. With these changes, FERC has the authority to order transmitting utilities to provide wholesale transmission service to any electric utility, Federal power marketing agency, or any other entity generating electric energy for resale.

Based on its experience with implementing EPAct, FERC reached the conclusion that Section 211 alone was not enough to provide non-discriminatory open access. In order to improve and streamline the process for transmission open access, FERC released the Open Access Notice of Proposed Rulemaking (NOPR) ${ }^{4}$ in March 1995. After substantial debate and comment, FERC promulgated FERC Order 888 on April 25, 1996. ${ }^{5}$ Among other requirements and conclusions, FERC Order 888 requires all public utilities that own, control or operate facilities used for transmitting electric energy in interstate commerce to:

- file open access non-discriminatory transmission tariffs that contain minimum terms and conditions of non-discriminatory services (e.g., the open access tariffs must offer both network, load-based service and point-to-point, contract-based service);

- take transmission service (including ancillary services) for their own new wholesale sales and purchases of electric energy under the open access tariffs; and

- develop and maintain an information system that will give existing and potential transmission users the same access to transmission information that the public utility enjoys, and further requires public utilities to separate transmission from generation marketing functions and communications.

4. FERC, Promoting Wholesale Competition Through Open-Access Non-Discriminatory Transmission Service by Public Utilities and Recovery of Stranded Costs by Public Utilities and Transmitting Utilities, Notice of Proposed Rulemaking and Supplemental Notice of Proposed Rulemaking, 60 FR 17662, April 7, 1995

5. FERC, Promoting Wholesale Competition Through Open-Access Non-Discriminatory Transmission Service by Public Utilities and Recovery of Stranded Costs by Public Utilities and Transmitting Utilities, Order No. 888, Final Rule, 75 FERC 61,080, April 24, 1996 
The concept of an Independent System Operator (ISO) was borne even before EPAct, and it was further developed in the context of debates on electricity restructuring in California and New York. Major concerns were raised in these deliberations about electric utility ownership of both generation and transmission assets, and the ability of transmission owners (TOs) who also own generation to provide credible non-discriminatory access. The ISO concept was introduced as a way to accomplish non-discriminatory access without requiring generation or transmission divestiture.

FERC recognized the development of the ISO concept in FERC Order 888 and set out eleven principles to be used in assessing any ISO proposals that may be submitted to the Commission in the future.

FERC's Principles for ISOs (from Order 888)

1. The ISO's governance should be structured in a fair and non-discriminatory manner.

2. An ISO and its employees should have no financial interest in the economic performance of any power market participant. An ISO should adopt and enforce strict conflict of interest standards.

3. An ISO should provide open access to the transmission system and all services under its control at non-pancaked rates pursuant to a single, unbundled, grid-wide tariff that applies to all eligible users in a non-discriminatory manner.

4. An ISO should have the primary responsibility in ensuring short-term reliability of grid operations.

5. An ISO should have control over the operation of interconnected facilities within its region.

6. An ISO should identify constraints on the system and be able to take operational actions to relieve those constraints within the trading rules established by the governing body.

7. The ISO should have appropriate incentives for efficient management and administration and should procure the services needed for such management and administration in an open competitive market.

8. An ISO's transmission and ancillary services pricing policies should promote the efficient use of and investment in generation, transmission, and consumption. An ISO or an RTG of which the ISO is a member should conduct such studies as may be necessary to identify problems or appropriate expansions.

9. An ISO should make transmission system information publicly available on a timely basis via an electronic information network consistent with the Commission's requirements.

10. An ISO should develop mechanisms to coordinate with neighboring control areas.

11. An ISO should establish an ADR process to resolve disputes in the first instance.

- An ISO proposal is in the early stages of development for the Southwest Power Pool (SPP ISO), which would serve all or parts of Arkansas, Louisiana, Mississippi, Missouri, Kansas, Oklahoma, Texas, and New Mexico.

- The MAPP region is also developing an ISO proposal, which could encompass a region from eastern Montana to Iowa (MAPP and SPP are also jointly studying consolidation).

- The Midwest ISO will soon be filed to serve a region in eleven states from Wisconsin to Kentucky and parts of Ohio, Pennsylvania and Tennessee.

- The Wisconsin Public Utilities Commission plans to develop a proposal for a statewide ISO.

The only region in which at present there is no public effort to develop an ISO proposal is the Southeast (Virginia through Mississippi), including Florida. It should also be noted that there are instances of utilities that are not participating in ISO proposals that encircle or adjoin their service 
Table 2-1: Summaries of ISO Proposals

\begin{tabular}{|c|c|c|c|c|c|c|c|c|}
\hline Nane, & $\begin{array}{l}\text { Planned } \\
\text { Operation } \\
\text { Date } \cdots\end{array}$ & $\begin{array}{l}\text { Proposal } \\
\text { Status } \\
\end{array}$ & $\begin{array}{l}\text { Type of } \\
\text { Organi- } \\
\text { zation : }\end{array}$ & $\begin{array}{l}\text { Poprer } \\
\text { Exchange } \\
\text { (PX)? }\end{array}$ & $\begin{array}{l}\text { Control: } \\
\text { Areas } \\
\end{array}$ & $\begin{array}{l}\text { ISO } \\
\text { Grid** }\end{array}$ & $\begin{array}{l}\text { Type of } \\
\text { Board }\end{array}$ & $\begin{array}{l}\text { Trans- } \\
\text { mission } \\
\text { Tariff }\end{array}$ \\
\hline $\begin{array}{l}\text { ISO-NE } \\
\text { New England }\end{array}$ & mid 1997 & $\begin{array}{l}\text { Cond. } \\
\text { Approved }\end{array}$ & Non-profit & $\begin{array}{l}\text { ISO is } \\
\mathrm{PX}\end{array}$ & Single & $\begin{array}{l}69 \mathrm{kV} \\
\text { and up }\end{array}$ & $\begin{array}{l}\text { Inde- } \\
\text { pendent }\end{array}$ & $\begin{array}{l}\text { Postage } \\
\text { stamp }\end{array}$ \\
\hline $\begin{array}{l}\text { NY ISO } \\
\text { New York }\end{array}$ & Q4 1997? & $\begin{array}{l}\text { Before } \\
\text { FERC }\end{array}$ & $\begin{array}{l}\text { Not-for- } \\
\text { profit }\end{array}$ & $\begin{array}{l}\text { Separate } \\
\text { PX }\end{array}$ & Single & $\begin{array}{l}115 \mathrm{kV} \\
\text { and up }\end{array}$ & $\begin{array}{l}\text { Inde- } \\
\text { pendent }\end{array}$ & Zonal \\
\hline $\begin{array}{l}\text { PJM Inter- } \\
\text { connection } \\
\text { PA, NJ, MD }\end{array}$ & $3 / 31 / 97$ & $\begin{array}{l}\text { Interim } \\
\text { approval }\end{array}$ & Non-profit & $\begin{array}{l}\text { ISO is } \\
\mathrm{PX}\end{array}$ & Single & $\begin{array}{l}230 \mathrm{kV} \\
\text { and up }\end{array}$ & $\begin{array}{l}\text { Inde- } \\
\text { pendent }\end{array}$ & Zonal \\
\hline $\begin{array}{l}\text { CA ISO } \\
\text { California }\end{array}$ & $1 / 1 / 98$ & $\begin{array}{l}\text { Phase I } \\
\text { approved }\end{array}$ & $\begin{array}{l}\text { Non- } \\
\text { profit }\end{array}$ & $\begin{array}{l}\text { Separate } \\
\text { PX }\end{array}$ & Single & not avail. & $\begin{array}{l}\text { Stake- } \\
\text { holder }\end{array}$ & Zonal \\
\hline $\begin{array}{l}\text { ERCOT ISO } \\
\text { Texas }\end{array}$ & $12 / 96$ & $\begin{array}{l}\text { Tex. PUC } \\
\text { approved }\end{array}$ & Non-profit & No PX & Multi & not appl. & $\begin{array}{l}\text { Stake- } \\
\text { holder }\end{array}$ & $\begin{array}{l}\text { Postage } \\
\text { stamp } \\
\text { w/dist. } \\
\end{array}$ \\
\hline $\begin{array}{l}\text { IndeGO } \\
\text { Northwest }\end{array}$ & 7/99 & $\begin{array}{l}\text { To file } \\
\text { 4Q } 1997\end{array}$ & Non-profit & No PX & Multi & $\begin{array}{l}230 \mathrm{kV} \\
\text { and up }\end{array}$ & $\begin{array}{l}\text { Inde- } \\
\text { pendent }\end{array}$ & Zonal \\
\hline $\begin{array}{l}\text { Midwest ISO } \\
\text { Midwest U.S. }\end{array}$ & 2000 & $\begin{array}{l}\text { To file } \\
\text { 4Q } 1997\end{array}$ & Non-profit & No PX & Multi & $\begin{array}{l}60 \mathrm{kV} \\
\text { and up }\end{array}$ & $\begin{array}{l}\text { Inde- } \\
\text { pendent }\end{array}$ & Zonal \\
\hline $\begin{array}{l}\text { DesertSTAR } \\
\text { AZ, NM, NV }\end{array}$ & 2002 & not avail. & Non-profit & No PX & Multi & $\begin{array}{l}230 \mathrm{kV} \\
\text { and up }\end{array}$ & $\begin{array}{l}\text { Unde- } \\
\text { cided }\end{array}$ & Zonal \\
\hline
\end{tabular}

\subsection{Characteristics of ISOs Proposed and Underway}

The following sections summarize the characteristics of these ISO proposals, some of the key issues that have been addressed in defining ISOs, and the relevant guidance FERC has provided on formation of ISOs. For more details on specific ISOs and ISO proposals, refer to Appendix B.

\subsubsection{ISO Proposal Development Process}

Utilities have initiated and lead the ISO proposal development process in most instances; in some areas (California, New England, New York, Texas, Arizona), regulators or legislators have also pushed restructuring and ISO development. The processes have in many instances been largely closed to non-utility interested parties during an initial period (Midwest, PJM, IndeGO, MAPP), while in others stakeholders have been involved from early in the process (CA, ERCOT, NY, NEPOOL, DesertSTAR, SPP). Parties eager to participate in ISO development include munis and coops, marketers, large customers, and associations representing these interests, among others. 
FERC has made it clear in a PJM ruling that the ISO development process must be open and give stakeholders an opportunity for real participation.

The processes have ranged from quite rapid (ERCOT was given three months by the Texas PUC to develop a proposal, implementation occurred months later) to extended over years. The differences reflect the complexity of the changes being contemplated, the perceived urgency of the process, and the ease with which the parties have found common ground.

\subsubsection{Purpose, Scope of the ISO}

FERC's views on the broad purposes and scope of ISOs were stated in their original eleven principles (included above). However, the primary goals and purposes in forming ISOs have varied from region to region. The relative importance of reliability management, non-discriminatory transmission operation, transmission tariff and scheduling simplification, bulk power market facilitation, and transmission planning coordination vary by region, and this is reflected in the details of the proposals.

Generally, ISOs are being proposed with the following broad functions and responsibilities:

- Provide non-discriminatory transmission access:

- Provide a single, transparent, non-pancaked tariff

- Schedule transmission

- Run OASIS

- Resolve congestion;

- Functionally control the system, either directly or through directives to control areas;

- Perform operational planning;

- Provide/procure ancillary services;

- Provide reliability management; serve as NERC Security Coordinator;

- Facilitate bulk power markets (but in most cases not operate a power exchange);

- Coordinate scheduling of transmission maintenance;

- Lead regional system planning efforts; and

- Provide system information on a timely and non-discriminatory basis, and maintain confidentiality of information as appropriate.

An example of an ISO with relatively limited authority would be ERCOT, which need not file with FERC and would most likely not meet FERC's requirements. The ERCOT ISO does not have direct control of generation (this is characteristic of several of the ISO proposals), does not provide ancillary services, coordinates between control areas which remain primarily responsible for reliability, and serves only a coordinating role between the utilities in transmission planning.

ISOs with more extensive authority such as California, NEPOOL or PJM are the sole control areas in the region, the sole providers of transmission and most ancillary services in the region, are NERC Security Coordinators with prime responsibility for regional security, and take lead roles in regional transmission planning. 


\subsubsection{ISO Founding Documents and Agreements}

Founding documents for ISOs are taking a few different forms. Where power pools existed, the founding documents include amended or restated pooling agreements (NEPOOL, PJM). Elsewhere, founding documents generally include:

- Articles of Incorporation for the ISO;

- Bylaws, describing purposes, membership, Board of Directors, voting, amendment, dispute resolution;

- Transmission Control Agreement(s) between TOs and the ISO, describing the circumstances of the transfer of control of transmission facilities to the ISO, and the rights and obligations of each party:

- Precise facilities to be transferred, date, term

- ISO right to identify additional facilities under ISO control

- TO right to sell, lease or dispose of assets

- TO obligation to physically operate facilities according to ISO directives

- ISO and TO responsibilities under emergency circumstances

- Maintenance standards; TO maintenance responsibilities; maintenance scheduling procedures

- ISO and TO responsibilities in system planning

- Extent of TO responsibility to exercise eminent domain, pursue approvals, build

- Right and procedure for additional TOs to join the agreement

- Billing and payment

- Record-keeping and information-sharing requirements

- Right of access to facilities

- Liability of TOs to ISO, of ISO to TO, insurance;

- Generation and Load Connection Agreements (between connected generation and loads and the ISO), describing each parties rights and obligations; or this can be part of the tariff; and

- Open access tariff for provision of transmission and ancillary services.

FERC has stated a preference for a single document forming the ISO, but this probably does not preclude structuring the documents as shown above, as the various documents can become attachments to a transmission control agreement.

In most cases, the nature of the creation of an ISO is an offer by the TOs, approved by FERC, to create the ISO, transfer control of facilities to it, and operate under a new ISO tariff. The details are decided and formalized in documents before the ISO is formed. FERC represents the interests of other parties, who participate in the process but without authority. The resulting rights and obligations of transmission users under the deal are defined in the Tariff and/or in generation and load connection agreements.

The TOs give up control of their facilities to the ISO and cannot dominate ISO decision-making or governance according to FERC requirements. Understandably, the TOs are concerned that the ISO, once formed and out from under their control, will not change into a different organization from what 
they had in mind or take actions or adopt procedures substantially different from what they expected and agreed to, harming their interests in some way. The TOs' assurance that this won't happen comes through specific restrictions in the transmission control agreement and other founding agreements. Stability can also be provided by making it difficult to change the ISO founding documents and ISO procedures (such as by requiring super-majority Board votes or even unanimous approval by TOs of certain changes). Such inflexibility in a newly-invented institution such as an ISO could be a problem if it restricts the ISO's ability to adapt and fine-tune itself to its new role, fixing the inevitable problems that will arise during the period of initial operation and striving for ever more efficient and effective fulfillment of its functions.

ISO founding documents provide the TOs with the right to withdraw from the ISO. A substantial prior notice must be given ( 3 months in one proposal, two years in other), and withdrawal is typically not allowed during the first years of ISO operation. Any TO withdrawing from an ISO would have to file a new tariff with FERC, so FERC essentially must approve the withdrawal, and can be expected to require that the benefits of the ISO are not lost in the process.

\subsubsection{Nature of the ISO Organization}

FERC has called for ISOs to be independent in terms of governance, budget approval and funding; no higher authority should be in a position to approve ISO decisions or budgets. All ISO proposals to date call for the ISO to be independent. Some ISOs are new organizations and entirely independent from any other organizations, while others are closely related to power pools but with independent governance and budget (NEPOOL, PJM). Still others may be related to or identical to NERC regional reliability councils (ERCOT, potentially SPP), although no such ISO has been proposed to FERC. Many ISOs are located in new offices established specifically for the purpose.

All ISO proposals to date call for non-profit status (PECO Energy, dissenting from the majority view in PJM, is proposing a for-profit ISO). This is an important attribute with a number of consequences. Clearly, non-profit status is consistent with the fundamental purpose of the ISO as an independent, non-discriminatory operator of the transmission system and provider of reliability management. Nonprofit status can also avoid taxation and reduce costs.

Were instead an ISO to be a profit-making entity, it is not clear where the ISO should earn profits and why. A for-profit ISO would have to have owners (shareholders), to whom profits accrue; who should they be, and how could the FERC requirement of broad, non-dominated governance be assured? If profits are somehow being passed back to transmission users, what is the purpose (why not just reduce fees)? It is not clear how a profit-making ISO could be designed to resolve these questions in an effective manner.

On the other hand, there are drawbacks to non-profit status. It is hard to impose performance incentives on an organization with no owners and minimal assets. If the organization performs well and earns a bonus (or performs poorly and is penalized), it makes little sense to add to or subtract from its operating budget. In fact, transmission users would likely prefer that rather than reducing 
ISO service, any penalties for poor performance be passed on to users and ISO funding and service be maintained. The only possibility for incentives would be at the individual officer or staff level. But staff-level incentives, to truly motivate performance, should be based on outcomes that depend on individual staff performance to a substantial degree; this would be impossible for many of the ISOs most important objectives such as bulk power system reliability.

One organizational approach is to contract out most or all of the ISO function to a separate organization; the ISO is then essentially a governance "shell". While such an approach could improve ISO management and incentives, it could also weaken the Board of Directors' control, and this might result in opposition to the arrangement from stakeholders. The approach was considered and then rejected for PJM, and is being considered for the Midwest ISO and perhaps other ISOs.

\subsubsection{Governance}

Independence of the ISO is, according to FERC, "the bedrock on which an ISO is built". FERC ISO Principle 1 states that "the ISO's governance should be structured in a fair and non-discriminatory manner... the primary purpose of an ISO is to ensure fair and non-discriminatory access to transmission services and ancillary services for all users of the system. As such, an ISO should be independent of any individual market participant or any one class of participants (e.g., transmission owners or end-users). A governance structure that includes fair representation of all types of users of the system would help ensure that the ISO formulates policies, operates the system, and resolves disputes in a fair and non-discriminatory manner. The ISO's rules of governance, however, should prevent control, and appearance of control, of decision-making by any class of participants."

Most ISOs have a membership and a Board of Directors. Membership in an ISO is generally voluntary and open to eligible transmission customers and transmission-owning utilities. Affiliates of members are generally not allowed to have separate membership; for instance, a transmissionowning utility's generation division cannot join or joins as a non-voting member.

Members have the opportunity to participate in the ISO and be informed of its actions. The most important power of the membership is usually to elect the Board of Directors. Otherwise, the authority of membership is restricted to approving changes to some of the governance and membership-related aspects of the ISO founding documents.

One reason for restricting the authority of members is the difficulty in designing a balanced voting mechanism. One-member one-vote would potentially give transmission owners, munis and coops little voice if end users, marketers, brokers, etc. joined in large numbers. Voting could also be weighted, but any weighting mechanism would likely be cumbersome and contentious. For these reasons, most ISOs assign even fundamental decisions (of the type that would be under the authority of the stockholders in a for-profit corporation) to the Boards of Directors. 
The most important governance institution, fundamental to the independence of the ISO, is therefore the Board of Directors. There are two general approaches being considered and proposed to accomplish a Board that is independent and not dominated by any interest:

- Board of Representative Directors (stakeholder board). A board consisting of directors who represent particular interest groups. Independence of the Board is ensured by carefully balancing the number of directors representing each interest group. The California ISO's bylaws, for instance, define 13 distinct interest groups and assign a specific number of seats on the Board to each group (total 26). Identified interest groups often include transmission owners, load-serving entities, munis and coops, generators, marketers, end customers.

- Board of Independent Directors. This approach strives to elect directors who are intended to be independent and not represent or favor any particular interest.

Hybrid approaches are also followed, in which some directors are elected by interest groups (membership subclasses) and others are elected in another manner and intended to represent all or additional interests. This approach is being proposed for the MAPP ISO, for instance.

A board made up of representative directors ensures effective representation of major interests and independence through balance. However, it could also be prone to stalemates. Such directors could be expected to vote in the narrow interest of their constituency rather than taking the greater good into account. Good decisions that are not in the interests of enough subclasses could be blocked In some ISOs, the electing members have the authority to remove a director without cause, further ensuring that directors will be disciplined in their representation of their constituency.

As to boards of independent directors, it is difficult to design an election process to accomplish this. There are two general approaches:

1. Require broad support, voting by membership class. Members are organized into subclasses by interest group, and vote for directors according to one-member, one-vote, as is the typical approach for electing a board of representative directors. To be elected director, a candidate must receive support across membership classes according to some rules, such as a minimum level of support in each class. The IndeGO ISO is proposing such a voting rule, and the Midwest ISO election procedure also has such attributes. Run-offs are used if the approach is at first unsuccessful.

2. Independent nominees. This approach can involve an executive search firm to develop a list of qualified and independent candidates; a nominating committee (probably consisting of a balanced number of representatives of various interests) to shorten the list; and ultimately voting by members, perhaps with a weighting mechanism, to identify the elected directors. The NEPOOL ISO initial board was elected in a manner similar to this.

In identifying and electing an independent board, it is generally a goal to achieve a mix of skills and experience (electric power and other industry experience; business, finance, markets, etc.). 
An additional concern about boards of independent directors, expressed by FERC, is that the directors be sufficiently knowledgeable and close to the interests of the membership; not so independent as to be detached and unaware of the issues. Given that most ISO boards may meet only a few times per year and directors will most likely spend a minority of their time fulfilling their obligations as directors, this is can be a real concern.

Another approach to gaining the benefits of both types of boards is through a two-tier structure. The lower tier could be a stakeholder board, and the higher tier a smaller, independent type board. The higher board would generally take a passive role, and would act only if the lower, stakeholder board either was stalemated or put forth a decision that was unacceptable from the broader interest standpoint. California has a structure similar to this, with an Oversight Board, appointed by the Governor, that oversees the decisions of both the ISO and power exchange stakeholder boards?.

Additional goals of governance arrangements and Board voting rules pertain to the ability of groups to force or block decisions. FERC in a California ruling ${ }^{8}$ added that no one class should be able to block or veto action, and no two classes should together be able to form a sufficient majority to make decisions. For instance, if a $2 / 3$ vote of the Board is required for some decisions, no one group should have over $1 / 3$ of the votes on the Board.

In most cases ISOs will require that directors have no financial interest in market results or affiliation with market participants. FERC in the NEPOOL conditional approval ${ }^{9}$ rejected any threshold on financial interests, and required that directors divest all interests in market participants within one year of their election.

FERC has, however, also accepted boards of affiliated directors as long as all interest groups are allowed to elect affiliated directors. On the current California ISO Board, for instance, all but a few directors are directly affiliated with transmission owners, munis, coops, marketers, end-users, environmental organizations, etc. or associations representing such groups.

\subsubsection{Dispute Resolution}

All ISO proposals include dispute resolution procedures, as required by FERC ISO principle 11, to resolve disputes around the ISO's various agreements, procedures, and tariff. Disputes can arise between transmission users and the ISO, between transmission owners and the ISO, or between

7. Despite what might seem to be an abundance of governance in California, many stakeholders feel that the CA-ISO, established earlier this year, has been acting too independently under the tight California implementation schedule.

8. Pacific Gas and Electric Company, et al., Order Conditionally Authorizing Establishment of an Independent System Operator and Power Exchange, Conditionally Authorizing Transfer of Facilities to an Independent System Operator, and Providing Guidance, 77 FERC 61,204, Docket Nos. EC96-19-000 and ER96-1663-000, November 26, 1996

9. New England Power Pool, Order Conditionally Authorizing Establishment of an Independent System Operator and Disposition of Control Over Jurisdictional Facilities, 79 FERC 61,374, Docket No. EC97-35-000, June 25, 1997 
members. Dispute resolution procedures are often based on previous pool, reliability council, or regional planning association dispute resolution procedures, and typically involve:

- A balanced dispute resolution committee to oversee the process, select mediators and arbitrators, etc.;

- Requirement that the parties to a dispute attempt to resolve the dispute through negotiation before initiating the dispute resolution process; and

- Mediation with a set time limit, followed if necessary by arbitration with a set time limit.

Transmission users and owners have the right to appeal to FERC if they believe that FERCjurisdictional contracts, agreements or tariffs are being violated. Consequently a primary purpose of dispute resolution is to reduce the number of ISO-related disputes that end up before FERC. If a dispute resolution process is well-designed, it should be the case that the dissatisfied party would have little hope or chance that FERC would change the arbitrator's decision, and would not bother to pursue the dispute this far.

\subsubsection{ISO Control of Transmission}

The most critical legal relationship in the creation of an ISO, that between the transmission owners and the ISO, can be defined in a separate transmission control agreement or in broader founding documents of the ISO.

The facilities transferred are generally defined to be those making up the transmission network or critical to bulk system security; this was considered to generally include $230 \mathrm{kV}$ and up in one instance, $60 \mathrm{kV}$ and up in another. FERC has required that the ISO have the authority to identify additional facilities that need to be under ISO control. As tariffs generally provide coverage for revenue requirements, this may not be as contentious an issue between TOs and the ISO as might have been expected.

A key difference among ISOs is that some plan to operate as a single control area, while others will maintain multiple control areas, at least for some period of time. FERC in a decision on the Primergy merger case ${ }^{10}$ accepted the notion of an ISO encompassing multiple control areas, "with the decision to move to a single control area in the future when and if the ISO decides." The Midwest ISO, for example, would encompass 19 control areas and while consolidation is recognized as a goal, no plan is identified in the ISO proposal.

Where ISOs will have subordinate control areas, FERC has accepted that control will in most cases be "virtual": the ISO will "functionally" control the system by issuing directives to the control area operators rather than directly controlling facilities. How tightly linked the ISO will be with

10. MidContinent Area Power Pool, et al., Order Accepting for Filing and Suspending Proposed Pool-Wide and Single-System Holding Company Open Access Transmission Tariffs and Revised Tariffs, and Deferring Further Action, February 28, 1997 
subordinate control areas through telecommunications and systems will apparently also vary substantially.

\subsubsection{ISO Role in Reliability Management}

Most ISOs are to serve as the NERC Security Coordinator for the grid they control. This will place certain responsibilities and authority on the ISO as described in a previous section of the report:

- Next day security analysis and information sharing;

- Identifying the need for and selecting special operating procedures (redispatching generation, modification of interchange transactions, or transmission reconfiguration);

- Determining generation deficiencies;

- Identifying transmission system problems, notifying other Security Coordinators, and implementing relief as needed, including redispatch or curtailment;

- Declaring system emergency and directing redispatch or curtailment; and

- Determining when the system has returned to a normal state and informing others.

In a few instances the ISO would not be the Security Coordinator, existing control areas will continue this role. This is the arrangement in ERCOT, for instance.

FERC has stated that an acceptable ISO must be obligated to follow NERC and regional council reliability policies and procedures, and transmission control agreements will typically require this. ISOs will develop specific procedures for emergency management based on NERC policies as applied to local conditions. ISOs will also develop procedures for congestion relief and for ancillary services provision, two areas where commercial and reliability issues intersect. It is yet to be seen whether the procedures developed by the potentially more commercially-oriented ISOs raise issues of compliance with the policies developed by the relatively more engineering-oriented reliability organizations.

Compliance with certain reliability standards is likely to be required of transmission users under either the ISO tariff or in connection or other agreements with the ISO. NERC's traditional doctrine holds control areas (as system operators) responsible for the compliance of connected generation and loads. This would translate into responsibility falling on ISOs for monitoring and enforcement of reliability compliance of market participants, including transmission owners. Again, there is the possibility that the ISO, which may balance reliability and commercial considerations differently from the reliability organizations, may choose to monitor compliance and levy sanctions for violations with less diligence than the reliability organizations recommend.

In New York, the utilities have proposed the formation of a new entity, the New York State Reliability Council (NYSRC), to be responsible for determining specific reliability standards based on NERC and NPCC policies. This proposal reflects the concern of the utilities that they, and not the ISO, may continue to be held responsible and liable for reliability. Governance of the NYSRC 
would be dominated by the transmission owners, and the ISO would be required to implement the NYSRC's standards and procedures.

In many systems there are certain generators that must run (or be available to run) at certain times in order to ensure the reliability of the system. To prevent such generators from exerting market power, they may be required to operate under special rules or contracts and not be permitted to bid freely into the wholesale power market. ISOs may be responsible for determining which units must be designated as "must-run" or "must-be-available" and entering into contracts with them.

\subsubsection{ISO Role in Maintenance Scheduling}

The ISO generally will coordinate transmission maintenance scheduling, and have the authority to reject proposed maintenance schedules if they would have a detrimental effect on the efficient use or reliable operation of the grid. In a few instances the ISO actually schedules transmission maintenance based on TO requirements. TOs are responsible for performing maintenance in all ISOs. The ISO in some cases is involved in setting maintenance standards and in monitoring maintenance.

FERC has recently called for the ISO to also coordinate generation maintenance to the extent such maintenance affects transmission capacity or transmission reliability ${ }^{11}$. As markets are expected to provide generators with appropriate incentives to schedule maintenance when capacity is least needed (at least, absent market power circumstances), most ISOs envision a minor role for the ISO in generation maintenance scheduling.

\subsubsection{ISO Role in Transmission Access and Pricing}

ISOs will provide one-stop shopping for transmission scheduling within the region of the ISO controlled grid, under a single, non-pancaked tariff as required by FERC. The ISO will operate the OASIS system and be responsible for calculating Available Transfer Capability (ATC). Transmission owners will also be required to schedule transmission through the ISO.

Many ISOs will initially offer "zonal" or "license plate" transmission pricing, in which the charge for a particular transaction depends only on the destination but not the source of the power. The zones are usually (but not in every case) identical to existing TO service territories, and the charges are calculated to provide coverage of the TO's revenue requirements, at least initially. Wheeling in charges may also be zonal, while wheeling out or through charges are generally a single rate for any transaction.

11. Pacific Gas and Electric Company, San Diego Gas \& Electric Company, Southern California Edison Company, Order Providing Guidance and Establishing Procedures, 80 FERC 61,128, Docket Nos. EC96-10-003 and ER961663-003, July 30, 1997 
The ISO will also generally bill for transmission services, collect and distribute revenue to transmission providers.

\subsubsection{ISO Role in Congestion Management}

ISOs will be responsible for identifying constraints on the system and working to relieve them, as required by FERC. The typical process involves identifying likely congestion situations based on dayahead schedules and forecasts. ISOs will likely vary in how actively they work to resolve congestion. At one extreme they may provide the information about congestion and leave it to the market to resolve; or they may facilitate or even suggest redispatch; or they may invite increment/decrement bids and redispatch to resolve congestion based on the bids.

In most ISOs the ISO's goal is narrowly defined as relieving congestion; the ISO will not redispatch to achieve a more efficient use of available generation resources. Indeed, in most cases the ISO will not have the cost or price information that would be needed for such a redispatch.

\subsubsection{ISO Role in Ancillary Services Provision}

The FERC in Order 888 required that control area operators provide six ancillary services; two that can only be obtained from the control area operator (system control and voltage control) and four that transmission users may self provide or obtain elsewhere (regulation, operating and spinning reserves, and energy imbalance). This obligation is considered to transfer to the ISO upon formation. Some transmission control agreements explicitly address demands of transmission users that TOs provide ancillary services, requiring the ISO to take on this obligation. The ISO will procure the services competitively or contract for them rather than owning or controlling the facilities necessary to provide them.

ISOs will be responsible for determining the quantities of ancillary services required in aggregate and in support of specific transactions based on NERC standards. ISOs will also be responsible for ensuring that all transactions are supported by the required ancillary services, and can reject schedules if the required ancillary services are not available.

Proposals vary in the extent to which the ISO will operate competitive markets for ancillary services. In California, it is proposed that the ISO will operate day-ahead and hourly auctions for regulation, spinning reserves, non-spinning reserves and replacement reserves to meet demands that are not selfprovided. Voltage support and black start capability, for which the potential for competition is limited by the location-dependence of demand, will be contracted on a longer term basis.

\subsubsection{ISO Role in System Planning}

FERC has called for the ISO to take a lead role in transmission system planning. Proposals generally call for a collaborative process involving planning at both the TO and ISO levels, with the ISO performing its own analyses, coordinating and integrating. 
Some proposals would essentially obligate the TOs to build projects identified through the ISO planning process, while others call for "best efforts" or "due diligence". In every case dispute resolution applies. As FERC also has certain authority to compel TOs to build, it may not be a crucial difference that some ISOs lack such authority.

Most proposals acknowledge the possibility of third parties building and owning transmission. For the foreseeable future only the TOs will possess eminent domain authority, so ISOs and third parties will be dependent upon them for siting and other approvals. Some ISO proposals set a goal of obtaining eminent domain authority for the ISO.

Most if not all proposals call for planning in accordance with NERC and regional council planning policies.

\subsubsection{ISO Role in Ensuring Generation Adequacy}

Opinions vary as to the need to augment market incentives for construction of new generating capacity. Many feel that market prices for energy, capacity, operating reserves, other ancillary services, congestion, etc. will provide adequate and appropriate incentives. Others are concerned that markets will not anticipate future needs in a sufficiently timely manner, permitting periods of capacity shortage.

There are two general approaches to creating additional incentives or requirements to provide adequate generating capacity for the future. One is to maintain the traditional forward capacity reserve requirement, allocated to load serving entities proportionally or on some other basis. This is difficult to apply under the new circumstances, as the amount of load any entity is responsible to meet could change by a large fraction at any time, and no entity may be responsible for some portion of total load. Some ISO proposals call for maintaining reserve requirements at least for a transitional period.

The other approach is to create additional incentives for capacity as part of real-time prices. In the U.K., for instance, a capacity availability component is added to market prices that is calculated based on the probability and value of lost load in any hour. When capacity is tight and the probability of losing load (based on computer modeling) increases, this additional payment can be a substantial reward to available generators and an incentive to potential investors. 


\section{ISOs and Their Role in Bulk Power System Reliability: Issues, Questions and Policy Options}

This section raises issues and questions on the evolving characteristics of ISOs and how they will fulfill their various responsibilities, and suggests potential policy options.

As was seen in the previous section, there are many similarities and also significant differences between existing ISO proposals. Most ISOs won't be in full operation for at least a year or two, and it will take additional time before it becomes clear which approaches are most effective. Consequently differences of opinion about how ISOs should be structured and uncertainty about the best approaches will continue for some time to come.

This section summarizes some of the issues and questions around ISO design which may determine how successful ISOs will be and the future directions in the evolution of the ISO concept. Policy options that could help to resolve some of the issues are also suggested.

\subsection{Issues and Questions about ISO Formation}

The issues to be raised here pertain to the following broad categories:

- Transfer of functional control over transmission to the ISO;

- Providing non-discriminatory transmission access;

- Geographic sizes of ISOs;

- Effectiveness of ISO Governance;

- Ability of ISOs to evolve and to improve their operating procedures;

- Incentive and liability issues resulting from the ISO's non-profit status;

- Possible alternatives to ISOs;

- Role and performance of ISOs in reliability management;

- Effectiveness of ISO-led regional transmission planning; and

- Interface between the ISO and market operations.

\subsubsection{Transfer of Functional Control}

Will the fundamental concept of an ISO - as a controller, but not owner, of transmission - work well?

The transmission control agreements attempt to define an effective assignment of responsibilities and authority between the ISO and the transmission owners, including responsibilities for safety, emergency operations, maintenance, etc. This raises all of the usual issues around contract performance: what each party's incentive is to perform according to the contract, whether each party 
will be able to monitor the other party's performance effectively, etc. The split of responsibility needs to be sufficiently precise, to avoid ambiguity or the exercise of market power.

Where there are multiple control areas, the ISOs will exercise "virtual" control of transmission through directives to the control areas. The effectiveness of such an arrangement will depend upon the strength of the transmission control agreements and on the supporting telecommunications and other systems. Most multiple-control-area ISOs intend to move toward consolidation over time, which should streamline both commercial and security functions.

\subsubsection{Provision of Non-discriminatory Transmission Access}

Will the ISO exercise sufficient control to accomplish non-discriminatory operation and access?

This will depend on many factors, including the adequacy of ISO control over transmission, the degree of flexibility and discretion in rules and procedures, the effectiveness of market monitoring (by the ISO, PX, regulator, market participants, etc.), access to sufficient information to analyze market operations, etc. ISOs need sufficient control to prevent TOs from creating subtle barriers to generators that would compete with their affiliates.

\subsubsection{Geographic Sizes and Boundaries of ISOs}

\section{How flexible will ISOs be to change their boundaries if needed over time?}

Larger ISOs, or much larger ISOs (the size of the eastern or western interconnection) could be more effective in terms of transmission scheduling, system operation, and security, and more convenient for transmission users. The coordination problems involved in consistently and reliably scheduling ISO-to-ISO transactions would be eliminated by larger ISOs. The drawback would be the requirement that to form them, even broader and more diverse interests and companies, with less history of cooperation, would have to come together and agree. The need to accommodate so many interests could result in such super-ISOs having less effective governance than smaller ISOs with boundaries that reflect historical spheres of cooperation. The rapid implementation of the Texas ISO, and the relative lack of problems during its history of operation, are attributed partly to the fact that the ISO was based on a geographic region in which the relevant parties had a long history of working together.

If any of the initial ISOs are later considered to be too small, it will hopefully be feasible for them to combine to form larger ISOs. The process could involve ISOs combining, or transmission owners withdrawing from one ISO and joining another, or an ISO dissolving and the member transmission owners joining one or more other ISOs. Policy-makers may be able to create incentives for such combinations.

A related issue is whether ISOs will welcome non-participating or adjoining utilities, or whether there will be barriers to new TOs joining. 


\subsubsection{Effectiveness of ISO Governance}

\section{Which approaches to ISO governance will provide the most effective decision-making?}

Boards made up of representatives of narrow stakeholder groups could be characterized by stalemate, as such directors could be expected to vote according to their constituencies' narrow interests. Especially if voting procedures allow small coalitions to block action, needed changes could be difficult to achieve. An unanticipated loophole in some ISO rules that provides a clearly undeserved benefit to certain groups could be impossible to fix if the groups control enough votes on the Board of Directors to block a rules change.

There is also a reasonable concern that ISO Boards made up of independent directors could have weak governance, as directors may be so independent as to be detached or uninformed of the issues. It could be difficult to find candidates that will be both independent and sufficiently knowledgeable. One result could be that such ISOs have weak Boards and all but the most important or controversial issues are resolved within the ISO organization. If, however, the ISOs are successful in attracting highly capable officers and staff, this could be a favorable outcome.

Hybrid or two-tier approaches, which combine the advantages of involvement of both independent and stakeholder directors, could be appropriate.

\subsubsection{Ability of ISOs to Evolve and Adapt Procedures}

\section{How will ISOs adapt and evolve as necessary to effectively fulfill their functions?}

The final stages of preparation of ISO proposals involve input from a broad range of stakeholders, and the final result involves many compromises among the various parties. All parties face many uncertainties about how the ISO will function and about the industry more broadly. So it is understandable that once a compromise on the ISO is achieved, the parties are inclined to prefer stability over flexibility with regard to procedures for changing ISO documents, agreements, procedures and rules. Care should be taken to ensure that ISO procedures do not make it overly difficult to change the ISO founding documents or ISO procedures. ISOs, as newly-invented institutions, need flexibility to evolve and adapt to best fill their roles, without which it could be difficult to make adjustments as they gain operating experience.

Where the TOs have rights to withdraw from the ISO relatively soon after its formation, this could give them an additional way to exert influence over policy changes. However, the need for any withdrawing TO to gain FERC approval on a new tariff should make withdrawal (as either a threat or a reality) less likely.

Inflexible ISO rules and processes could also result in the ISO, and ultimately FERC, facing larger numbers of ISO-related disputes, as rules problems go unfixed and provide cause for grievance. 


\subsubsection{Incentive and Liability Issues}

\section{How effective will incentives or sanctions be for a non-profit ISO?}

Establishing incentives or sanctions for a non-profit organization is challenging. This includes incentives for effective performance, as called for in FERC's ISO principles, and also sanctions for reliability non-compliance, which are an important element of enforceable compliance arrangements. Several mechanisms which might be used to implement incentives include:

- The ISO itself could receive incentives or pay sanctions, increasing or decreasing its operating budget. Increases could be passed on to employees or refunded to transmission users. Decreases could reduce employee bonuses or the ISO operating budget. Reducing the operating budget would seem to require a reduction in ISO service or service quality, which would punish, in fact, transmission users, who might collectively prefer to pay the sanction and maintain service.

- Incentives/sanctions could pass to officers and staff through incentive bonus plans. This would be appropriate only to the extent that individual performance can be reasonably linked to ISO performance. However, ISO-level objectives (reliability, reliability compliance, nondiscrimination, cost-effective operation, etc.) may be difficult to relate to individual performance in most instances.

- Incentives/sanctions could be passed along to transmission users (directly or indirectly).

Given the likely limited efficacy of incentive schemes, oversight by Boards of Directors, interested parties and regulatory authorities will play an important role in assuring adequate performance of these institutions.

\section{How will liability issues be addressed?}

Non-profit status also raises issues around the potential liability of the ISO. Should an ISO be found liable for actions that result in damage to transmission owners or users, the ISO's insurance may cover most of the costs (the insurance premiums are of course paid by transmission users through tariffs as an operating expense). In an extreme case where insurance won't cover the cost (for instance, if gross negligence was involved), a non-profit ISO with minimal assets may be effectively judgement-proof. The cost could ultimately land on the transmission owners or on transmission users (either specific ones who suffered the damage, or all users through rates in what amounts to a risksharing arrangement).

While these may be extremely unlikely situations, the resolution of such liability issues could be a stumbling block for some potential ISOs or ISO participants.

This issue existed to some extent for the power pools (NEPOOL, PJM, NYPP), but it could become much more important as the industry restructures and becomes more competitive. 


\subsubsection{Possible Alternative to ISOs}

\section{Could Transcos provide an alternative to ISOs?}

While most of the current focus is on ISOs, some suggest that there will ultimately be a transition to regulated, for-profit Transcos that combine system operation with transmission ownership. A regulated for-profit transmission company might more naturally address issues related to the separation of control and ownership, and incentive or liability issues.

A transition from ISO to Transco, especially where numerous transmission owners are involved, could be difficult. An ISO that owns some, but not all transmission, one possible transitional arrangement, raises a concern that the ISO would favor its own transmission, and independence and non-discrimination would be compromised.

\subsubsection{Role and Performance of ISOs in Reliability Management}

How will ISOs effectively manage reliability?

In the current proposals, ISOs are being assigned reliability management functions, through their management of the transmission system and in their Security Coordinator role. To be effective, the ISO will need sufficient operational control and authority, and will need to gain the confidence of all interested parties in its ability to maintain reliability.

Where the ISO is not a security coordinator, there would seem to be the possibility of ambiguous responsibility, or coordination problems. The separation of commercial transaction scheduling from analysis of interchange physical flows become an increasing concern in this circumstance.

What balance will ISOs achieve between commercial and reliability objectives?

Commercial and reliability issues intersect in almost all of the ISO's procedures (transmission scheduling, congestion relief, ancillary services procurement, line loading relief, curtailment, etc.). These procedures will be developed and modified within the ISO based on NERC and RRC standards. In the process, ISOs must strike a balance between reliability, efficiency, fairness, confidentiality of information, and other objectives.

Due to the early stage of most ISO proposals and implementation, many of these procedures are not fully designed. Hence, it is too early to judge how ISOs will, for instance, procure ancillary services utilizing markets where possible. This issue is particularly crucial during the transition from simpler approaches to the use of more market-oriented approaches. 
The extent of ISO responsibility for monitoring and enforcement of the reliability compliance of transmission users is not yet clear. Nor is it clear to what extent ISOs will establish sanctions and develop or tailor monitoring and enforcement procedures, adapted to local conditions, or whether these procedures will be imposed on the ISO from NERC/RRC. Even if largely imposed on the ISO, there will undoubtedly be some flexibility in how these procedures are applied. The reliability organizations and ISOs have to resolve any differences in views about the appropriate balance of reliability and commercial values to avoid discrepancies between intended and actual enforcement.

ISOs must also provide confidence that reliability rules are not being used in an anticompetitive way to exercise market power. Curtailments during emergencies or during congestion could be viewed as discriminatory if they disproportionately affect various types of transmission users.

\section{How will ISOs share reliability responsibility with NERC/RRC?}

The RRCs' roles will be clarified as the new reliability management system is defined. The RRCs' roles may decline as the ISO takes on many of the functions, and also standards development may be increasingly centralized under NERC in order to maintain consistency and enforceability. ISOs should work smoothly with RRCs and NERC especially if the governance structures and objectives of the various organizations are similar.

In some areas, the ISO and RRC geographic boundaries may not coincide (for instance, the Midwest ISO). This will increase the need for coordination or perhaps the RRC will be reconfigured such that the boundaries do coincide.

\subsubsection{Effectiveness of Regional Transmission Planning}

\section{How will ISOs lead effective regional transmission planning?}

ISOs are charged with lead roles in transmission system planning. In most ISOs their plans are to have a high degree of authority, and in some they will be able to compel TOs to build. However, they will be dependent upon TOs for siting and approvals. It is doubtful that ISOs will be much more effective in overcoming the many obstacles that exist today to transmission system expansion.

A key policy issue is whether ISOs will seek eminent domain authority or will continue to rely on the TOs' authority. Since local and/or state governments typically require approval of large projects, an important related issue is the extent to which state regulators will cooperate in supporting regional planning efforts.

One aspect of open access is the ability to connect new generation. If there are various barriers to connecting new generation, and especially if the TOs are in control of some of the key steps, questions could be raised about whether open access is being achieved. 


\subsubsection{ISO Interface with Bulk Power Markets}

How will ISOs resolve transmission congestion?

The authority of most ISOs is limited to transmission system operation. Most are charged with resolving congestion, for instance, with minimal impact on market transactions. ISOs will generally not have the information to perform a complete economic re-dispatch of the system, but will instead resolve congestion utilizing voluntary bids for incremental or decremental supply. This could potentially result in inefficient resolution of congestion situations. There is also the broader question of whether the ISO will be motivated and effective in squeezing the most it can out of scarce transmission.

\section{How will the separation of transmission operation from market operation affect efficiency?}

Some ISO proposals will allow multiple power exchanges and bilateral contracts, relying on the ISO to bring these various schedules together and identify and resolve congestion situations. The complexity of this task has the California ISO and PX spending hundreds of millions of dollars on new systems. It is too soon to tell whether this approach will result in the most open, flexible, and efficient power markets, or whether the more restrictive approaches applied in other countries (where mandatory pools are common) will be shown to have advantages.

\subsection{Policy Options}

This final section suggests some possible policy directions and options that could contribute to favorable resolution of some of the issues raised in this report. A starting point for these policy options is the widely-held view that more formal mechanisms will be required for ensuring compliance with reliability standards.

FERC has encouraged but not required ISOs, and has allowed considerable latitude in defining ISOs. Furthermore, FERC's guidance on the formation of ISOs has been addressed more to commercial than to reliability issues. Through its review and approval of ISO proposals and tariffs, FERC is developing its position on ISOs on a case-by-case basis. Consequently, many important aspects of ISO formation associated with reliability have been left ultimately to the proposal development efforts to decide.

The policy options presented here include potential additional guidance on the formation of ISOs, which could take the form of further FERC comments or federal legislation.

Possible policy options include the following:

1. The role of FERC in enabling enforcement of compliance with reliability-related provisions could increase: 
- $\quad$ FERC could require that all jurisdictional entities follow NERC and RRC policies and standards. FERC can do this now, but enforcement could potentially be successfully challenged without some legislative support. Before taking such a step, FERC would undoubtedly have to review and approve NERC and RRC governance and processes to ensure that their work involves sufficient input from interested parties, is nondiscriminatory and in the public interest.

Legal limitations to delegation of authority would apply (the Securities and Exchange Commission is the precedent on this). FERC would retain authority to review and approve or reject reliability standards and specific instances of enforcement, and appeal of any sanctions to FERC would remain available. The intent would be for the industry organizations (NERC, RRCs, ISOs) to play the large roles and insulate FERC from dayto-day involvement in reliability policy and enforcement.

- Another approach would be for FERC to become directly involved in processes to adopt reliability rules and standards and then enforce them along with the NERC/RRC. This would require a significant expansion of FERC's capabilities and authorities.

- $\quad$ FERC does not have the authority to impose reliability compliance on non-jurisdictional entities, specifically municipals, cooperatives, Power Marketing Administrations, and TVA. These entities will remain regulated to some extent, and reliability is just as important to them as it is to other industry participants, so they may voluntarily enter into agreements that extent national reliability policies to them. Or legislation could be helpful to ensure a uniform national environment for reliability management.

2. There are presently initiatives underway involving NERC, DOE, and other interested parties to clarify the future bulk power system reliability management system and the roles of industry organizations (NERC, RRCs, and ISOs) in it.

3. The Department of Energy's statutory role in monitoring and reporting on reliability issues could be strengthened, especially during the transitional period when roles are changing. This monitoring and reporting role would be a natural complement to FERC's existing and potentially larger role in reliability enforcement.

4. Additional FERC guidance on ISOs, perhaps in the form of a policy statement, could address other issues that have an impact on the effectiveness of ISOs. Such additional guidance could address ISO formation, effective governance, ISO adaptability (adequately flexible procedures for amending rules and agreements), etc.

5. FERC could also take a role in encouraging larger ISOs. It is generally agreed that larger ISOs have some advantages. While it is probably too late to influence the sizes of many of the initial ISOs, special attention could be given to governance structures, terms of founding documents, and other details that could present barriers to ISO combinations in the future. 
6. The roles of states in ensuring bulk system reliability in the short- and longer-term is also not clear. States retain authority over siting and environmental compliance, so their involvement in planning is essential. Policies may be needed that support reducing barriers to broader geographic planning processes and the implementation of needed transmission system modifications. The formation of regional regulatory agencies to correspond to the geographical scope of ISOs, with authority delegated from state and federal authorities, could streamline the process for gaining necessary approvals for system enhancements.

7. The history of international cooperation and coordination on bulk power system planning and reliability issues must be continued. To maintain consistency in reliability policy through the transition from an industry self-regulatory system to one with regulatory backup will require close cooperation with the relevant authorities in Canada and Mexico.

8. Legislation to resolve liability issues may be needed in some states or at the federal level to permit changes in the industry and formation of effective ISOs. Legislation could ensure that the assignment of liability reflected in founding ISO documents will hold up against challenges. Legislation could also limit the potential liability of ISOs and/or clarify how such liability would be handled.

9. Since information access and confidentiality issues have and will likely continue to be contentious, regulatory and/or legislative actions could support requirements to provide information, and assurances of confidentiality. FERC could take a more active role in the implementation of OASIS systems across the U.S. 


\section{Appendix A \\ System Operation Arrangements. in Other Countries}

A number of other countries have restructured electric power sectors with the primary goal of achieving greater competition in the generation sector, which accounts for a majority of the cost of electricity. England and Wales is one of the best known and earliest examples; others are Norway; Chile; Argentina; Alberta, Canada and Victoria, Australia.

There are many published descriptions of how the electric power systems in these countries are structured and operate. This appendix will briefly review international analogies to some of the key attributes of the ISOs being proposed in the United States. In fact, few if any of the major attributes of proposed ISOs are new. Instead, it is the combination of attributes that makes the ISOs unique to the United States. The following paragraphs expand on this observation.

Separation of Ownership from Control of Transmission. In Victoria, the Victoria Power Exchange operates the market and also the transmission system, which is owned by a separate company, PowerNet Victoria. The Power Exchange operates the system under a contract which cedes a high level of control to the operator, as is proposed for most ISOs.

Non-profit System Operator. Most of the international power pools, which are also system operators, are non-profit entities. For-profit system operators also exist. National Grid Company in the U.K. is the system operator and transmission system owner (a Transco). In Norway, the system operator is a state-owned, profit-making corporation.

Independent Governance. Governance structures such as ISOs will have, in particular stakeholdertype governing boards, are common in these countries. The England and Wales and Alberta pools have stakeholder-type boards, while Victoria has a board with a mix of stakeholder and independent directors.

Separation of Market and Transmission Operation Functions. In most restructured power sectors the market and system operation functions are performed by the same entity or are very tightly integrated; for instance, the system could be operated by a separate entity under contract to the entity that governs the pool (England and Wales). In Norway the system operator and pool operator are separate, but affiliated companies.

International System Operator. In Norway and Sweden, the Nord Pool system operator controls a transmission system that crosses international boundaries.

Perhaps the most significant innovation in the U.S. pertains not to the ISO, but to the power exchange. Most international power exchanges are mandatory. In the U.S. power exchanges will 
generally be non-exclusive, and bilateral contracts and additional power exchanges will be allowed. The ISO will be responsible for consolidating the schedules that result from the various sources.

Also unique to the Unites States is the institution of a separate, industry-sponsored organization for developing reliability policies (NERC and the regional councils). In other countries reliability responsibility generally rests with the industry entities, with greater or lesser degrees of government involvement. 


\section{Appendix B \\ Characteristics of U.S. ISO Proposals}

This appendix summarizes some of the ISO proposals and discussions to date, in two groups:

B.1. Midwest ISO, IndeGO, ERCOT ISO and DesertSTAR.

B.2. California ISO, ISO New England, PJM (Supporting Companies) ISO, and New York ISO.

It should be noted that all of these ISOs are undergoing further definition and revision; the information provided here was gathered through September, 1997. Furthermore, it should be noted that DesertSTAR especially is at an early discussion stage. The information on all of these ISOs is based on public information and private conversations, and some of the information may have been misunderstood or misinterpreted.

The purpose of these tables is to show differences and similarities between the various proposals. Not all features that are common to all ISOs are described here. Refer to the main report for common features of most or all ISO proposals. 


\section{B.1 Summaries of the Midwest, IndeGO, ERCOT and DesertSTAR ISO Proposals}

\begin{tabular}{|c|c|c|c|c|}
\hline : & 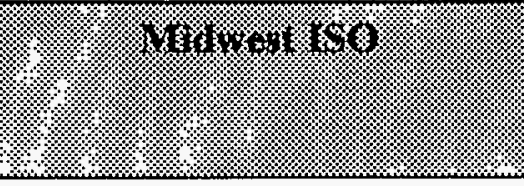 & : & \% & 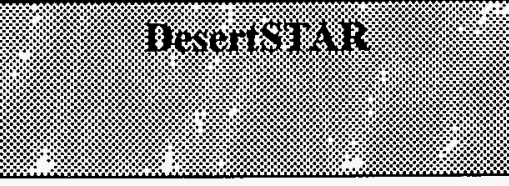 \\
\hline Name & $\begin{array}{l}\text { Midwest Independent Transmission } \\
\text { System Operator, A Limited } \\
\text { Liability Corporation (Midwest } \\
\text { ISO, LLC) }\end{array}$ & $\begin{array}{l}\text { Independent Grid Operator } \\
\text { (IndeGO) }\end{array}$ & $\begin{array}{l}\text { ERCOT ISO (same organization as } \\
\text { ERCOT, the Electric Reliability } \\
\text { Council of Texas) }\end{array}$ & $\begin{array}{l}\text { Desert Southwest Transmission and } \\
\text { Reliability Operator (DesertSTAR) }\end{array}$ \\
\hline World Wide Web page & www.midwestiso.org & $\begin{array}{l}\text { www.idahopower.com/ } \\
\text { ipindegol.htm }\end{array}$ & $\begin{array}{l}\text { www.ercot.com, } \\
\text { oasis.ercot-iso.com/tmoindex.htm }\end{array}$ & www.swrta.org/destar \\
\hline Geographic Scope & $\begin{array}{l}25 \text { utilities in portions of ten states: } \\
\text { Wisconsin, Illinois, Kentucky, Ohio, } \\
\text { West Virginia, Michigan, Indiana, } \\
\text { Missouri, Virginia, Tennessee }\end{array}$ & $\begin{array}{l}21 \text { utilities located in Washington, } \\
\text { Oregon, Idaho, Montana, Wyoming, } \\
\text { Nevada, Colorado and Utah }\end{array}$ & State of Texas & $\begin{array}{l}\text { Arizona, New Mexico, southern } \\
\text { Nevada, part of Texas }\end{array}$ \\
\hline $\begin{array}{l}\text { Proposed Date of } \\
\text { Operation }\end{array}$ & Year 2000 & $\begin{array}{l}\text { Transmission and ancillary services } \\
\text { 7/1/99; congestion relief beginning } \\
7 / 1 / 2000\end{array}$ & December 18, 1996 & $\begin{array}{l}\text { Phased implementation, with } \\
\text { FERC-approved ISO operational } \\
\text { status July 2002; Security } \\
\text { Coordinator, 1999. }\end{array}$ \\
\hline $\begin{array}{l}\text { Current Status of ISO } \\
\text { Proposal }\end{array}$ & Draft documents for review & Draft filing documents & Approved by Texas PUC. & "Straw man" under development \\
\hline $\begin{array}{l}\text { Date Discussions } \\
\text { Began }\end{array}$ & February, 1996 & $\begin{array}{l}\text { Memorandum of Understanding } \\
\text { July } 11,1996\end{array}$ & Texas PUC Order, 2/9/96 & $\begin{array}{l}\text { Memorandum of Understanding, } \\
\text { March, } 1997\end{array}$ \\
\hline $\begin{array}{l}\text { Date of Initial FERC } \\
\text { Filing }\end{array}$ & Planned for October 31, 1997 & Planned for autumn, 1997 & Not filed, not required to file. & Not scheduled \\
\hline $\begin{array}{l}\text { Organization of the } \\
\text { ISO development } \\
\text { effort }\end{array}$ & $\begin{array}{l}\text { Management Council, work groups; } \\
\text { each TO gets one vote. }\end{array}$ & $\begin{array}{l}\text { Work groups on Legal; Pricing; } \\
\text { Planning; Operations; Facilities; } \\
\text { Finance; Revenue Requirements; } \\
\text { Steering and Exec. Committees. }\end{array}$ & $\begin{array}{l}\text { Work groups on Operating Guides, } \\
\text { Transmission Losses, Transm. } \\
\text { Market Operations, Engineering, } \\
\text { Security }\end{array}$ & $\begin{array}{l}\text { Work teams on } \\
\text { Governance/Regulatory, Planning, } \\
\text { Operations, Pricing/Tariff }\end{array}$ \\
\hline $\begin{array}{l}\text { Other Participants in } \\
\text { the Process }\end{array}$ & $\begin{array}{l}\text { Stakeholders involved in recent } \\
\text { months }\end{array}$ & $\begin{array}{l}\text { IndeGO opened work groups to all } \\
\text { interested parties March } 1997 .\end{array}$ & $\begin{array}{l}\text { Wholesale market participants, } \\
\text { stakeholders, from the beginning }\end{array}$ & $\begin{array}{l}\text { Utility commissioners, marketers, } \\
\text { etc. }\end{array}$ \\
\hline
\end{tabular}




\begin{tabular}{|c|c|c|c|c|}
\hline 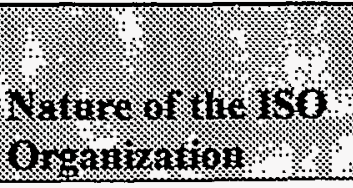 & : & (4) & (:) & (: \\
\hline $\begin{array}{l}\text { Organizational Form, } \\
\text { State of Incorporation } \\
\end{array}$ & $\begin{array}{l}\text { Limited Liability Company under } \\
\text { Delaware law }\end{array}$ & Utah non-profit corporation & Texas non-profit corporation & $\begin{array}{l}\text { Will incorporate in one of the four } \\
\text { states of ISO's operations }\end{array}$ \\
\hline Non-Profit Status & $\begin{array}{l}\text { Non-profit. ISO function may be } \\
\text { contracted out to a separate } \\
\text { organization. }\end{array}$ & Non-profit & Non-profit & Non-profit \\
\hline Location of Office & $\begin{array}{l}\text { Yet to be determined -- Board may } \\
\text { establish branch offices. }\end{array}$ & To be decided & Taylor, Texas & To be decided \\
\hline $\begin{array}{l}\text { Relationship to Other } \\
\text { Organizations }\end{array}$ & None, independent. & Independent & $\begin{array}{l}\text { Division of ERCOT regional } \\
\text { reliability council }\end{array}$ & Independent \\
\hline $\begin{array}{l}\text { Initial Capitalization, } \\
\text { source }\end{array}$ & Not available. & & & Estimated $\$ 36.7$ million. \\
\hline $\begin{array}{l}\text { Proposed Annual } \\
\text { Budget }\end{array}$ & not available. & & & Estimated $\$ 16.1$ million/year \\
\hline ISO Cost Recovery & $\begin{array}{l}\text { Adder to transmission rates to } \\
\text { recover expenses and capital costs. } \\
\text { Recovered from all load. Based on } \\
\text { annual forecast with true-up. }\end{array}$ & & $\begin{array}{l}\text { Fee allocated based on load shares } \\
\text { to load serving utilities. }\end{array}$ & \\
\hline
\end{tabular}




\begin{tabular}{|c|c|c|c|c|}
\hline 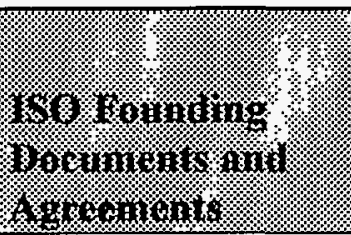 & l.4: & ?: & ?: & in: \\
\hline Founding documents & $\begin{array}{l}\text { Agreement Establishing the } \\
\text { Midwest ISO, 1.I.c.; Open Access } \\
\text { Transmission Tariff; filing letter } \\
\text { with attachments. }\end{array}$ & $\begin{array}{l}\text { Articles of Incorporation, Bylaws, } \\
\text { Transmission Control Agreement, } \\
\text { Generation Interconnection } \\
\text { Agreement, Customer } \\
\text { Interconnection Agreement, Tariff }\end{array}$ & $\begin{array}{l}\text { ERCOT Articles of Incorporation, } \\
\text { Bylaws, Operating Guides. Agency } \\
\text { Agreement (allows ISO to act as } \\
\text { agent for TOs w.r.t. tariffs). } \\
\text { Control over transmission is not } \\
\text { transferred. }\end{array}$ & $\begin{array}{l}\text { Articles of Incorporation, Bylaws, } \\
\text { tariff planned. } \\
\text { Generation Connection Agreement. }\end{array}$ \\
\hline $\begin{array}{l}\text { Authority to Amend } \\
\text { Founding Documents }\end{array}$ & $\begin{array}{l}2 / 3 \text { vote of Board except unanimous } \\
\text { vote of TOs required to change } \\
\text { composition of the Board during } \\
\text { first five years, TO access to ISO } \\
\text { books, revenue distribution, } \\
\text { fiduciary relationship, requirement } \\
\text { to comply with NERC, state laws, } \\
\text { etc. }\end{array}$ & $\begin{array}{l}2 / 3 \text { vote of Trustees, except some } \\
\text { provisions requiring membership } \\
\text { vote. }\end{array}$ & $\begin{array}{l}\text { Bylaws: } 2 / 3 \text { vote in each of six } \\
\text { membership classes. }\end{array}$ & $\begin{array}{l}\text { Majority vote of Board of Directors } \\
\text { except certain "sacred" provisions, } \\
\text { which may require member } \\
\text { ratification, perhaps } 75 \% \text { vote in } \\
\text { each member class. }\end{array}$ \\
\hline $\begin{array}{l}\text { Initial Term of ISO } \\
\text { Agreements }\end{array}$ & $\begin{array}{l}\text { Thirty years unless terminated } \\
\text { sooner. }\end{array}$ & $\begin{array}{l}\text { Until terminated by mutual } \\
\text { agreement of all TOs and ISO or by } \\
\text { withdrawal of TO }\end{array}$ & No specified & \\
\hline $\begin{array}{l}\text { Withdrawal from ISO } \\
\text { of TO }\end{array}$ & $\begin{array}{l}\text { TO can withdraw, effective } \\
\text { December } 31 \text { of the year following } \\
\text { the year notice is given, but not } \\
\text { earlier than five years following the } \\
\text { date the TO signed this agreement. }\end{array}$ & $\begin{array}{l}\text { TO may withdraw for any reason } \\
\text { upon two years written notice. If } \\
\text { TO becomes or assigns to a } \\
\text { Regional Transmission Company, } \\
\text { six months notice is required. Once } \\
\text { a TO gives notice to withdraw, any } \\
\text { other TO may give notice within } 90 \\
\text { days and withdraw concurrently. }\end{array}$ & $\begin{array}{l}\text { Not applicable. (Withdrawal from } \\
\text { ERCOT with } 30 \text { days notice). }\end{array}$ & \\
\hline Admission of New TOs & $\begin{array}{l}\text { Expansion welcome; connected } \\
\text { TOs can sign agreement to join. }\end{array}$ & $\begin{array}{l}\text { New TOs can join. Existing TOs } \\
\text { have Most Favored Nation clauses. }\end{array}$ & Not applicable & \\
\hline
\end{tabular}




\begin{tabular}{|c|c|c|c|c|}
\hline 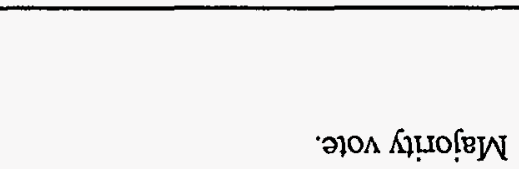 & 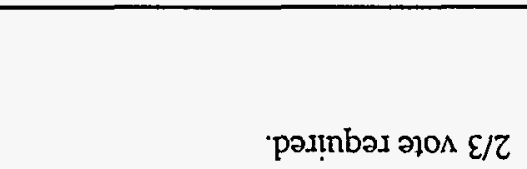 & 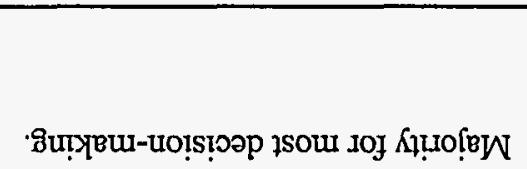 & 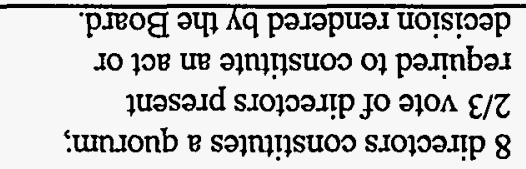 & 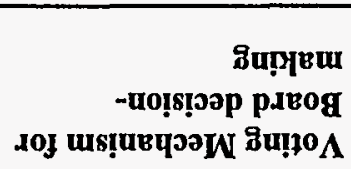 \\
\hline 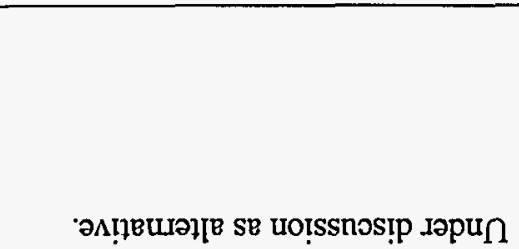 & 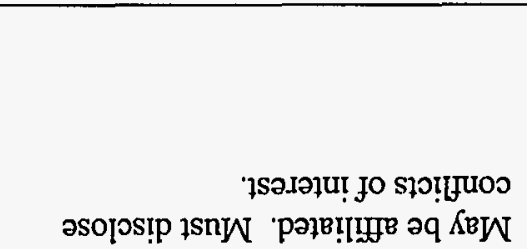 & 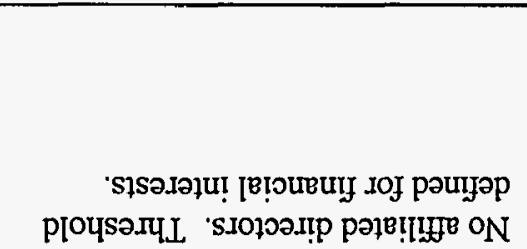 & 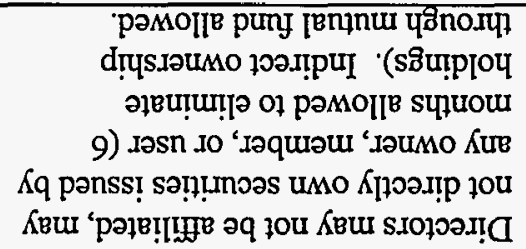 & 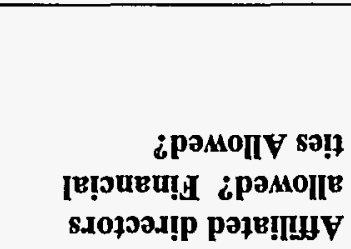 \\
\hline pəy!॰ads ı0N & 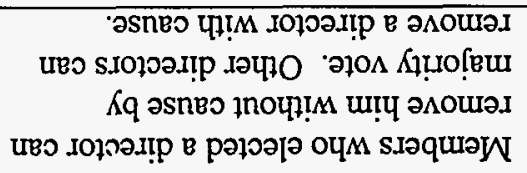 & 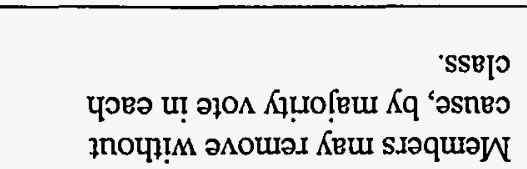 & 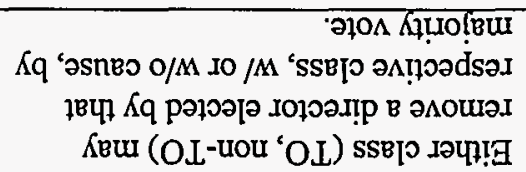 & 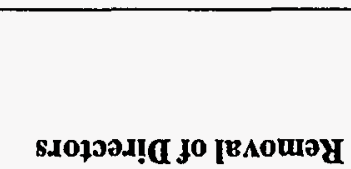 \\
\hline $\operatorname{SIBOK} \varepsilon$ & $\operatorname{IBOK} I$ & SГ⿻コK $\varepsilon$ & SIRəК $\varepsilon$ & 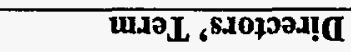 \\
\hline 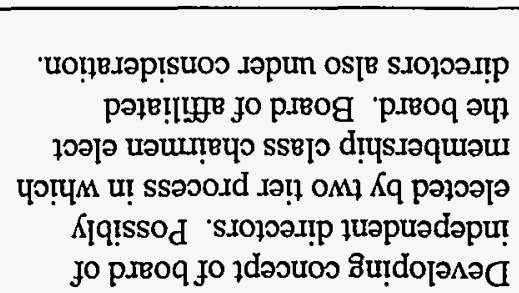 & 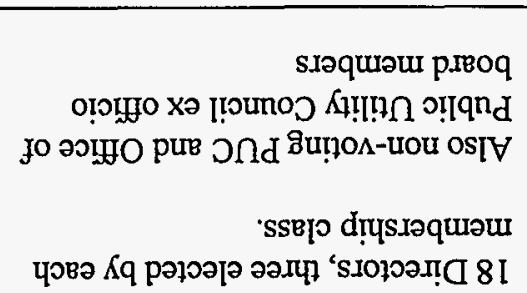 & 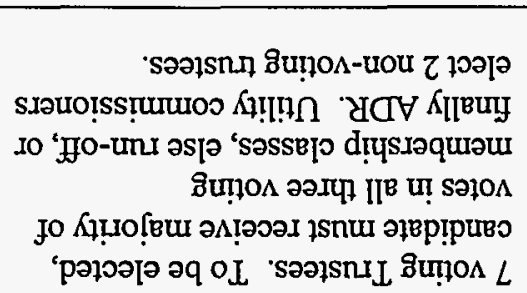 & 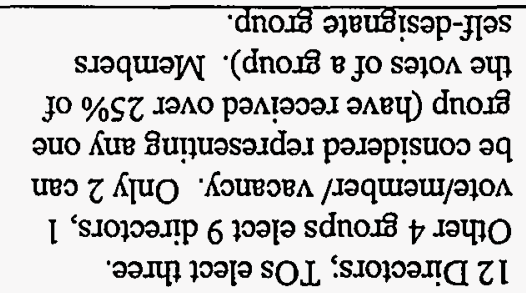 & $\begin{array}{r}\text { no!̣ısoduoj } \\
\text { s.dopodx! jo pxrog }\end{array}$ \\
\hline 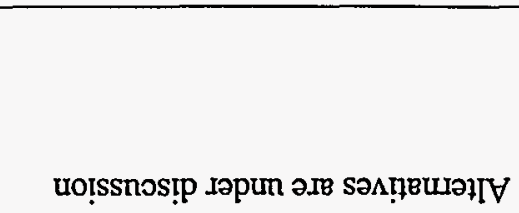 & 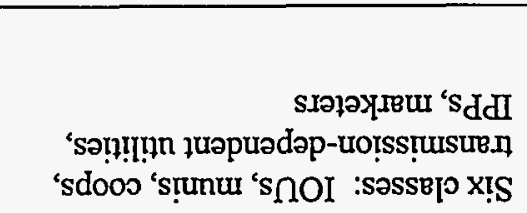 & 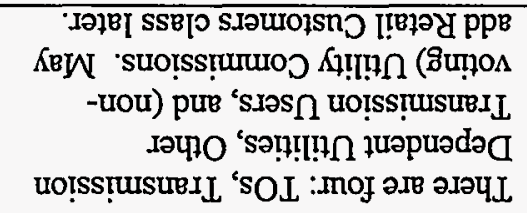 & 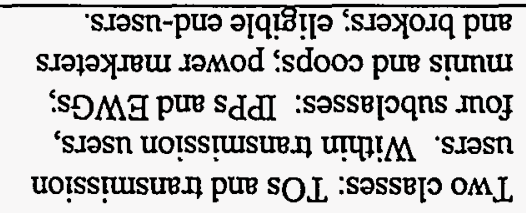 & səsselכ d!̣पs..əquəW \\
\hline 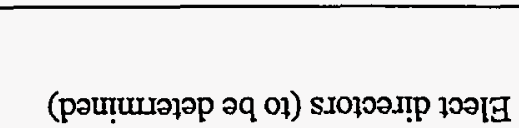 & 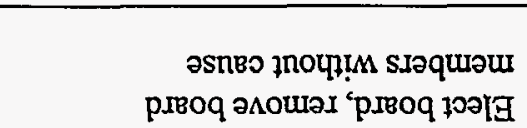 & 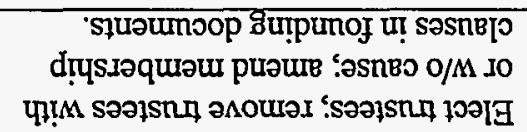 & 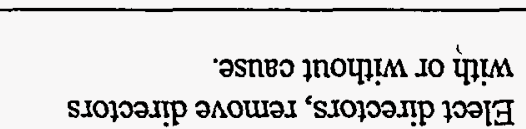 & 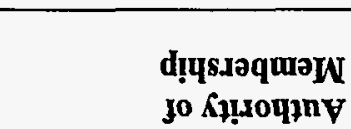 \\
\hline 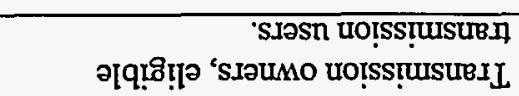 & 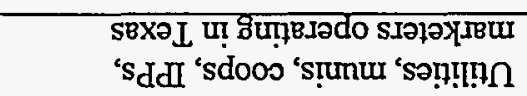 & 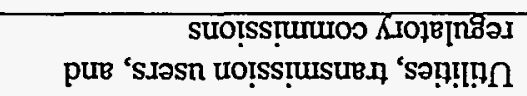 & 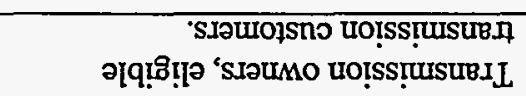 & 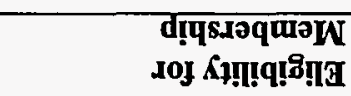 \\
\hline t) & i: & : & ( & 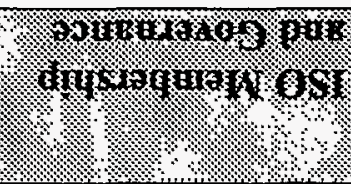 \\
\hline
\end{tabular}




\begin{tabular}{|c|c|c|c|c|}
\hline How: & i: & : & I: & I:=: \\
\hline ADR Committee & $\begin{array}{l}\text { Committee of six representatives } \\
\text { appointed by the by the Board (best } \\
\text { efforts to reflect diversity of Owners } \\
\text { and Members). }\end{array}$ & $\begin{array}{l}\text { None. Western Regional } \\
\text { Transmission Association } \\
\text { Arbitration Committee fills the role. }\end{array}$ & $\begin{array}{l}\text { ERCOT ADR procedure to be } \\
\text { modified based on } P U C \text { ruling. }\end{array}$ & $\begin{array}{l}\text { ADR to be defined, likely to be } \\
\text { based on Southwest Regional } \\
\text { Transmission Association } \\
\text { procedures. }\end{array}$ \\
\hline $\begin{array}{l}\text { Who Appoints ADR } \\
\text { Mediator, A rbitrator? }\end{array}$ & $\begin{array}{l}\text { Mediator will be chosen by the } \\
\text { Chairman of the ADR Committee. } \\
\text { The parties to a dispute may agree } \\
\text { on any person to serve as a single } \\
\text { arbitrator, or shall endeavor to } \\
\text { agree on a single arbitrator from a } \\
\text { list of arbitrators prepared by the } \\
\text { ADR Committee. }\end{array}$ & $\begin{array}{l}\text { WRTA Arbitration Committee } \\
\text { appoints arbitrator if parties cannot } \\
\text { agree. }\end{array}$ & $\begin{array}{l}\text { Parties to the dispute based on list } \\
\text { provided by PUC Secretary. }\end{array}$ & \\
\hline FERC Final Appeal & $\begin{array}{l}\text { A party may invoke FERC } \\
\text { jurisdiction within sixty days } \\
\text { following the arbitration } \\
\text { proceedings; must pay costs of other } \\
\text { parties involved. }\end{array}$ & $\begin{array}{l}\text { Within } 30 \text { days of arbitration } \\
\text { decision. }\end{array}$ & $\begin{array}{l}\text { ADR does not restrict any right to } \\
\text { ppeal to PUC Texas or to FERC. }\end{array}$ & \\
\hline ISO Liability & $\begin{array}{l}\text { ISO assumes liability for damage to } \\
\text { persons or property arising from its } \\
\text { own acts or neglect, otherwise } \\
\text { indemnified. }\end{array}$ & $\begin{array}{l}\text { IndeGO not liable to TO for results } \\
\text { of outage even if result of IndeGO } \\
\text { gross negligence or wrongful act } \\
\text { (but not willful act). IndeGO will } \\
\text { join existing Agreement Limiting } \\
\text { Liability Among Western } \\
\text { Interconnected Systems and related } \\
\text { insurance arrangement. }\end{array}$ & Not addressed & $\begin{array}{l}\text { Not addressed in current straw man } \\
\text { documents. }\end{array}$ \\
\hline TO Liability to ISO & $\begin{array}{l}\text { ISO indemnifies TOs from damages } \\
\text { and other costs or obligations by or } \\
\text { to third parties arising from ISO } \\
\text { performance or neglect unless TO } \\
\text { gross negligence or intentional } \\
\text { wrongdoing. }\end{array}$ & TO not liable unless "willful act". & Not addressed & \\
\hline ISO Insured? & Not available & $\begin{array}{l}\text { Western Interconnected Systems } \\
\text { Insurance }\end{array}$ & Yes & \\
\hline
\end{tabular}




\begin{tabular}{|c|c|c|c|c|}
\hline 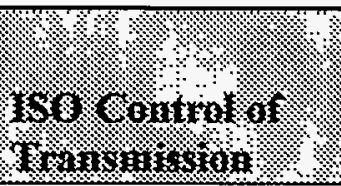 & (1) & - & (:- & : \\
\hline $\begin{array}{l}\text { Transfer of control of } \\
\text { facilities }\end{array}$ & $\begin{array}{l}\text { Control transferred according to } \\
\text { agreement. }\end{array}$ & $\begin{array}{l}\text { According to transmission control } \\
\text { agreement. }\end{array}$ & Control not transferred. & $\begin{array}{l}\text { ISO will lease transmission } \\
\text { facilities }\end{array}$ \\
\hline $\begin{array}{l}\text { Facilities Under ISO } \\
\text { Control }\end{array}$ & $\begin{array}{l}\text { MISO will control the operations of } \\
60 \mathrm{kV} \text { and above looped } \\
\text { transmission facilities. }\end{array}$ & $\begin{array}{l}\text { IndeGO will control transmission } \\
230 \mathrm{kV} \text { and above; also lower } \\
\text { voltage by contract where necessary } \\
\text { for reliability. }\end{array}$ & None. & $\begin{array}{l}\text { Generally } 230 \mathrm{kV} \text { and above; } \\
\text { facilitics critical to security or } \\
\text { having a significant impact on } \\
\text { transfer capability. }\end{array}$ \\
\hline $\begin{array}{l}\text { One Control Area or } \\
\text { Multiple? }\end{array}$ & $\begin{array}{l}\text { Multiple - } 19 . \text { No stated intentions } \\
\text { to reduce number. }\end{array}$ & $\begin{array}{l}\text { Multiple. Intention to eventually } \\
\text { operate as a single control area. }\end{array}$ & Ten control areas. & $\begin{array}{l}7 \text { control areas. May decide to } \\
\text { transition toward consolidation of } \\
\text { control areas if economically } \\
\text { feasible. }\end{array}$ \\
\hline $\begin{array}{l}\text { ISO has Direct } \\
\text { Control of Facilities? }\end{array}$ & $\begin{array}{l}\text { MISO will not physically change } \\
\text { the switches, will direct the TOs to } \\
\text { take the necessary actions. }\end{array}$ & $\begin{array}{l}\text { Existing control centers remain in } \\
\text { place, control is exercised through } \\
\text { them. }\end{array}$ & No & $\begin{array}{l}\text { Control exercised through existing } \\
\text { control areas }\end{array}$ \\
\hline TO control & $\begin{array}{l}\text { TOs can take facilities out of } \\
\text { service w/o ISO approval if } \\
\text { immediate hazard to persons or } \\
\text { facilities. }\end{array}$ & $\begin{array}{l}\text { TOs will continue to operate a fully } \\
\text { equipped control center for } \\
\text { executing switching orders, etc. } \\
\text { under IndeGO's direction. }\end{array}$ & $\begin{array}{l}\text { TOs continue to operate control } \\
\text { areas and all facilities. }\end{array}$ & $\begin{array}{l}\text { TOs must request and ISO approve } \\
\text { emergency maintenance and forced } \\
\text { outages. }\end{array}$ \\
\hline
\end{tabular}




\begin{tabular}{|c|c|c|c|c|}
\hline 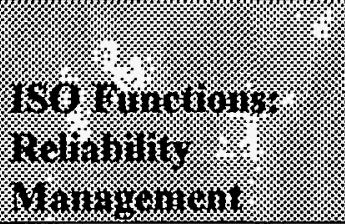 & אר. & 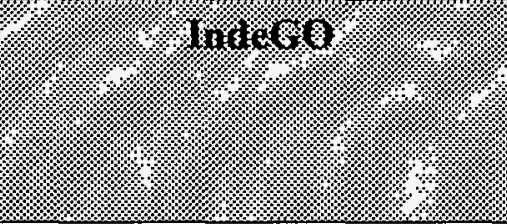 & ㄴ. & oforos \\
\hline $\begin{array}{l}\text { ISO is NERC Security } \\
\text { Coordinator? }\end{array}$ & $\begin{array}{l}\text { ISO will act as the security } \\
\text { coordinator of the region. ISO will } \\
\text { be responsible for monitoring and } \\
\text { emergency response. }\end{array}$ & $\begin{array}{l}\text { IndeGO will have full responsibility } \\
\text { for security of the bulk power } \\
\text { system, will serve as a NERC } \\
\text { Security Coordinator. }\end{array}$ & $\begin{array}{l}\text { Two security centers have been } \\
\text { combined into one under the ISO }\end{array}$ & $\begin{array}{l}\text { Yes, takes over WSCC Southwest } \\
\text { Security Coordinator center. }\end{array}$ \\
\hline $\begin{array}{l}\text { ISO Authority to } \\
\text { Resolve Reliability } \\
\text { Problems }\end{array}$ & $\begin{array}{l}\text { ISO has functional control over } \\
\text { system, can direct TOs to redispatch } \\
\text { generation etc. to resolve reliability } \\
\text { problems. }\end{array}$ & $\begin{array}{l}\text { Full authority to take any action } \\
\text { deemed prudent to maintain } \\
\text { reliability and integrity of grid. } \\
\text { Must have some AGC to fulfill } \\
\text { reliability function. }\end{array}$ & $\begin{array}{l}\text { ISO Security Operator authorized to } \\
\text { take actions to relieve severe } \\
\text { transmission problems, can direct } \\
\text { opening breakers, curtailment, } \\
\text { emergency power. }\end{array}$ & Security Coordinator \\
\hline $\begin{array}{l}\text { ISO Authority Under } \\
\text { Emergency } \\
\text { Circumstances }\end{array}$ & $\begin{array}{l}\text { ISO can order TOs to shed firm } \\
\text { load. Also ISO will operationally } \\
\text { control facilities including those not } \\
\text { part of the ISO-controlled } \\
\text { transmission system. }\end{array}$ & $\begin{array}{l}\text { Full authority to take any action } \\
\text { deemed prudent to maintain } \\
\text { reliability and integrity of grid. } \\
\text { Must have some AGC to fulfill } \\
\text { reliability function. }\end{array}$ & $\begin{array}{l}\text { Administers curtailment plan, } \\
\text { coordinates control area operations. }\end{array}$ & Security Coordinator \\
\hline TO responsibility & $\begin{array}{l}\text { TOs monitor security locally and } \\
\text { resolves problems. }\end{array}$ & $\begin{array}{l}\text { In accordance with IndeGO's } \\
\text { overall direction, TOs will monitor } \\
\text { and evaluate power and reactive } \\
\text { flows and voltage levels and take } \\
\text { action to maintain security of the } \\
\text { Transmission System. }\end{array}$ & $\begin{array}{l}\text { The reliability and security of the } \\
\text { interconnection ultimately remains } \\
\text { the responsibility of the control } \\
\text { areas. }\end{array}$ & \\
\hline $\begin{array}{l}\text { ISO Role in } \\
\text { Developing Reliability } \\
\text { Procedures }\end{array}$ & $\begin{array}{l}\text { ISO w/ owners, RRCs, Security } \\
\text { Coordinators develops regional } \\
\text { security plan. ISO w/members will } \\
\text { develop emergency procedures. } \\
\text { TOs' specific reliability } \\
\text { requirements and operating } \\
\text { guidelines also must be observed. }\end{array}$ & $\begin{array}{l}\text { Reliability criteria and performance } \\
\text { targets will be established by } \\
\text { IndeGO and the TOs, and will } \\
\text { include penalties and incentives to } \\
\text { meet reliability criteria. }\end{array}$ & $\begin{array}{l}\text { ISO is part of the ERCOT NERC } \\
\text { Regional Reliability Council. }\end{array}$ & $\begin{array}{l}\text { WSCC Regional Security Plan. } \\
\text { ISO authority and role in further } \\
\text { evolution of the plan not specified. }\end{array}$ \\
\hline
\end{tabular}




\begin{tabular}{|c|c|c|c|c|}
\hline 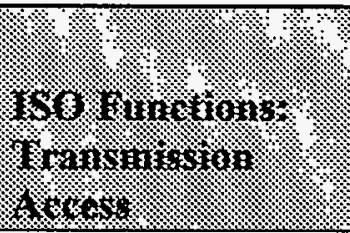 & (১) & : & : & (is: \\
\hline $\begin{array}{l}\text { ISO Operates OASIS, } \\
\text { computes ATCs }\end{array}$ & Yes & Yes & Yes & Yes \\
\hline $\begin{array}{l}\text { Reserve Transmission } \\
\text { Services }\end{array}$ & $\begin{array}{l}\text { ISO schedules all transmission } \\
\text { within and on the ISO-controlled } \\
\text { grid. }\end{array}$ & $\begin{array}{l}\text { IndeGO shall process Transmission } \\
\text { Service requests, including the } \\
\text { execution of all contracts for } \\
\text { Transmission Services. }\end{array}$ & $\begin{array}{l}\text { ISO processes transmission service } \\
\text { requests. Control areas can deny } \\
\text { requests if reliability would be } \\
\text { impacted. }\end{array}$ & $\begin{array}{l}\text { ISO responsible for pre-scheduling } \\
\text { and real time scheduling. }\end{array}$ \\
\hline $\begin{array}{l}\text { Congestion } \\
\text { Management } \\
\text { Approach }\end{array}$ & $\begin{array}{l}\text { ISO will provide information and } \\
\text { facilitate actions by transmission } \\
\text { users and generators to relieve } \\
\text { congestion. }\end{array}$ & $\begin{array}{l}\text { IndeGO will take bids on purchase } \\
\text { or sale of power to create reverse } \\
\text { flow (from } 7 / 2000 \text { ). }\end{array}$ & $\begin{array}{l}\text { ISO does not manage congestion, } \\
\text { but will help arrange dispatch on a } \\
\text { case-by-case basis. TOs obligated } \\
\text { to redispatch to relieve constraints. }\end{array}$ & $\begin{array}{l}\text { ISO may solicit purchase/sale bids } \\
\text { to create reverse flow to relieve the } \\
\text { congestion; or ISO may play a more } \\
\text { passive role, relying on the market } \\
\text { to create counterflow. }\end{array}$ \\
\hline $\begin{array}{l}\text { Billing and collection } \\
\text { for transmission } \\
\text { service }\end{array}$ & $\begin{array}{l}\text { ISO bills, collects and distributes } \\
\text { revenue. }\end{array}$ & IndeGO & TOs & Not addressed \\
\hline
\end{tabular}




\begin{tabular}{|c|c|c|c|c|}
\hline 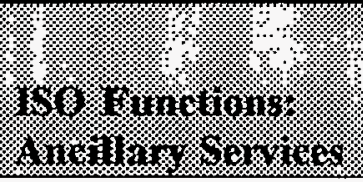 & (3: & $\frac{1}{4}$ & : & 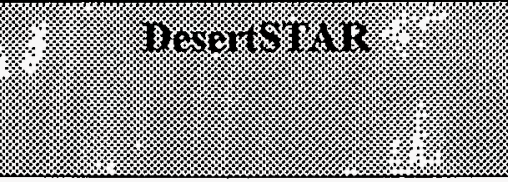 \\
\hline $\begin{array}{l}\text { Determination of } \\
\text { Quantities, Locations } \\
\text { Required }\end{array}$ & ISO & $\begin{array}{l}\text { IndeGO determines quantities, } \\
\text { solicits bids for Ancillary Services. }\end{array}$ & ISO & Responsibility phased in \\
\hline $\begin{array}{l}\text { Who Provides } \\
\text { Ancillary Service? }\end{array}$ & $\begin{array}{l}\text { ISO will offer to provide ancillary } \\
\text { services as required by FERC } 888 \text {; } \\
\text { ISO will not own or control } \\
\text { generation, but arrange to provide } \\
\text { the services. TOs required to } \\
\text { provide for or offer ancillary } \\
\text { services for loads in their area. }\end{array}$ & $\begin{array}{l}\text { IndeGO will provide ancillary } \\
\text { services, via competitive process to } \\
\text { the extent possible. TOs can } \\
\text { compete to provide Ancillary } \\
\text { Services. If IndeGO determines } \\
\text { that it has insufficient voluntary } \\
\text { bids, TOs shall upon IndeGO's } \\
\text { request submit bids to provide } \\
\text { Ancillary Services in any hour, to } \\
\text { the extent capable. }\end{array}$ & $\begin{array}{l}\text { ISO coordinates, TOs or third } \\
\text { parties provide. }\end{array}$ & $\begin{array}{l}\text { ISO will procure and provide } \\
\text { ancillary services, but responsibility } \\
\text { will be phased in. Initially, ISO will } \\
\text { be only a Security Coordinator, will } \\
\text { be responsible for reserves only. }\end{array}$ \\
\hline $\begin{array}{l}\text { Who Monitors that } \\
\text { Ancillary Services are } \\
\text { Provided? }\end{array}$ & $\begin{array}{l}\text { ISO monitors that scheduled } \\
\text { transactions are supported by } \\
\text { required ancillary services. Any } \\
\text { schedule request that proposes } \\
\text { ancillary services from other } \\
\text { sources can be rejected if services } \\
\text { inadequate. }\end{array}$ & IndeGO & ISO & Responsibility phased in \\
\hline $\begin{array}{l}\text { Billing and collection } \\
\text { for ancillary services }\end{array}$ & $\begin{array}{l}\text { ISO bills, collects revenue and } \\
\text { distributes revenue for ancillary } \\
\text { services. }\end{array}$ & $\begin{array}{l}\text { IndeGO will track and bill for } \\
\text { ancillary services. }\end{array}$ & TOs & \\
\hline
\end{tabular}




\begin{tabular}{|c|c|c|c|c|}
\hline 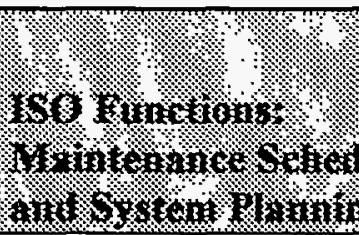 & (1) & lit: & : & (I: \\
\hline $\begin{array}{l}\text { ISO Role in } \\
\text { Transmission } \\
\text { Maintenance } \\
\text { Scheduling }\end{array}$ & $\begin{array}{l}\text { ISO coordinates, has } \\
\text { approval/rejection authority; in } \\
\text { addition, ISO can revoke previously } \\
\text { granted maintenance as necessary. }\end{array}$ & $\begin{array}{l}\text { IndeGO sets facility performance } \\
\text { criteria; IndeGO w/TOs work out } \\
\text { maintenance practices; TOs request } \\
\text { maintenance outages, IndeGO } \\
\text { approves based on operating } \\
\text { priorities, reliability concerns. }\end{array}$ & None & $\begin{array}{l}\text { ISO coordinates, approves } \\
\text { maintenance schedules subject to } \\
\text { efficiency and reliability } \\
\text { considerations. ISO together with } \\
\text { TOs establishes criteria, ISO } \\
\text { administers maintenance, TOs } \\
\text { perform maintenance. }\end{array}$ \\
\hline $\begin{array}{l}\text { ISO Role in } \\
\text { Generation } \\
\text { Maintenance } \\
\text { Scheduling }\end{array}$ & $\begin{array}{l}\text { ISO coordinates to the extent such } \\
\text { maintenance affects transmission } \\
\text { capacity or transmission reliability, } \\
\text { but has no approval/rejection } \\
\text { authority. }\end{array}$ & None & None & $\begin{array}{l}\text { Coordinates to ensure that reserve } \\
\text { margins met. }\end{array}$ \\
\hline $\begin{array}{l}\text { ISO Role in Regional } \\
\text { Planning }\end{array}$ & $\begin{array}{l}\text { ISO assumes overall responsibility, } \\
\text { plays lead role in collaborative } \\
\text { process; develops Transmission } \\
\text { Plan based on TO plans. Plan must } \\
\text { adhere to all applicable national, } \\
\text { regional and filed state and local } \\
\text { transmission system reliability } \\
\text { criteria. }\end{array}$ & $\begin{array}{l}\text { IndeGO will assume primary } \\
\text { responsibility for planning of the } \\
\text { IndeGO controlled grid. Will } \\
\text { perform studies, identify constraints } \\
\text { and options for relieving them. }\end{array}$ & $\begin{array}{l}\text { ISO and ERCOT Engineering } \\
\text { Subcommittee coordinate regional } \\
\text { transmission planning. }\end{array}$ & $\begin{array}{l}\text { Alternatives under consideration; } \\
\text { could involve substantial ISO role, } \\
\text { or continue SWRTA planning } \\
\text { process with ISO involvement. }\end{array}$ \\
\hline $\begin{array}{l}\text { ISO Can Compel TOs } \\
\text { to Build? }\end{array}$ & $\begin{array}{l}\text { TOs to use due diligence to build as } \\
\text { directed by ISO. }\end{array}$ & $\begin{array}{l}\text { No. TO will allow interconnection, } \\
\text { cooperate with siting, permits, } \\
\text { eminent domain. }\end{array}$ & No. & Yes. \\
\hline Who Builds? & TOs. & TOs or third parties. & TOs. & $\begin{array}{l}\text { TOs, potentially other entities } \\
\text { would build and own. }\end{array}$ \\
\hline $\begin{array}{l}\text { Long Term } \\
\text { Generating Capacity } \\
\text { Reserve Requirement? }\end{array}$ & Not addressed. & None. & ERCOT procedures. & Not addressed. \\
\hline
\end{tabular}




\begin{tabular}{|c|c|c|c|c|}
\hline S6 tyirit & 14: & 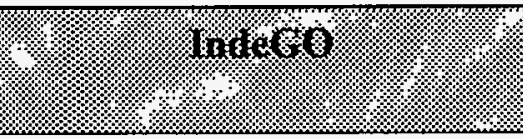 & 19.15: & 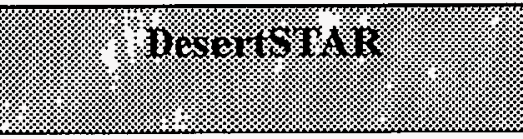 \\
\hline $\begin{array}{l}\text { Transmission } \\
\text { Charges: Approach }\end{array}$ & $\begin{array}{l}\text { Zonal rates by TO region for } \\
\text { network and point-to-point service } \\
\text { first four years, then phased out to a } \\
\text { single ISO-wide rate. }\end{array}$ & $\begin{array}{l}\text { Access charges based on broad } \\
\text { Access Price Areas and revenue } \\
\text { requirements. Also, transmission } \\
\text { capacity reservations (TCRs) } \\
\text { offered to provide price certainty. }\end{array}$ & $\begin{array}{l}\text { Access fee plus impact charge per } \\
\text { megawatt-mile. } \\
\text { Individual TOs have tariffs, also } \\
\text { ISO acting as agent for TOs. }\end{array}$ & $\begin{array}{l}\text { Zonal ("license plate") approach for } \\
\text { access charges; losses charged } \\
\text { separately. }\end{array}$ \\
\hline Wheeling Into & Zonal rate transitionally & & Access fee plus impact charge & Zonal rate \\
\hline $\begin{array}{l}\text { Wheeling Through, } \\
\text { Out }\end{array}$ & Average ISO rate & & Access fee plus impact charge & $\begin{array}{l}\text { Postage stamp rates developed for } \\
\text { each. }\end{array}$ \\
\hline Revenue Allocation & Based on revenue requirements & $\begin{array}{l}\text { Initially based on revenue } \\
\text { requirements. }\end{array}$ & Revenue requirements & \\
\hline $\begin{array}{l}\text { Congestion Charges: } \\
\text { Approach }\end{array}$ & $\begin{array}{l}\text { Costs incurred to prevent } \\
\text { curtailment of already committed } \\
\text { firm transmission spread among all } \\
\text { load. }\end{array}$ & $\begin{array}{l}\text { Congestion cleared by accepting } \\
\text { bids for reverse transfer; these costs } \\
\text { are paid by the users of the } \\
\text { congested path during the hour. }\end{array}$ & $\begin{array}{l}\text { For planned transactions, redispatch } \\
\text { costs shared by all users. For } \\
\text { unplanned transactions, paid by } \\
\text { customer. }\end{array}$ & $\begin{array}{l}\text { Congestion costs to be passed } \\
\text { through to entities causing } \\
\text { congestion. }\end{array}$ \\
\hline $\begin{array}{l}\text { Recovery of New } \\
\text { Investment: Approach }\end{array}$ & $\begin{array}{l}\text { For years } 1-8 \text {, the Transmission } \\
\text { Customers who caused the upgrade } \\
\text { will pay an annual carrying charge } \\
\text { on the facilities and an embedded } \\
\text { rate; credit if others use the facility. } \\
\text { In year nine, all network upgrades } \\
\text { to be rolled-in to base transm. rates. }\end{array}$ & $\begin{array}{l}\text { Interzonal: Users who pay } \\
\text { congestion costs agree to pay for } \\
\text { construction, receive tradable } \\
\text { capacity rights. Intrazonal: } \\
\text { Construction funded through } \\
\text { increase in access fee. }\end{array}$ & & \\
\hline
\end{tabular}


Summaries of the California, New England, PJM (Supporting Companies) and NY ISO Proposals

\begin{tabular}{|c|c|c|c|c|}
\hline 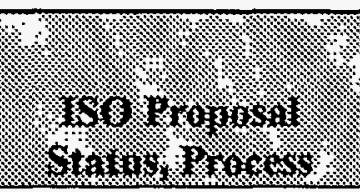 & 25. & 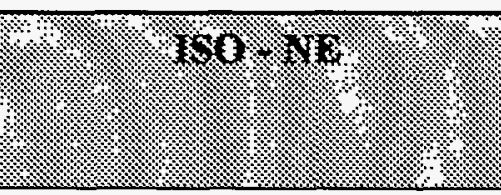 & (1. & (5. \\
\hline Name & $\begin{array}{l}\text { California Independent System } \\
\text { Operator }\end{array}$ & ISO New England, Inc. & PJM Interconnection, L.L.C. & $\begin{array}{l}\text { New York Independent System } \\
\text { Operator }\end{array}$ \\
\hline World Wide Web page & $\begin{array}{l}\text { www.energyonline.com/ } \\
\text { wepex }\end{array}$ & www.ne-iso.com & $\begin{array}{l}\text { www.pjm.com (PJM } \\
\text { Interconnection) }\end{array}$ & www.nypowerpool.com (NYPP) \\
\hline Geographic Scope & State of California & $\begin{array}{l}\text { New England States: Maine, } \\
\text { Vermont, New Hampshire, } \\
\text { Connecticut, Massachusetts, Rhode } \\
\text { Island }\end{array}$ & $\begin{array}{l}\text { Most of Pennsylvania, New Jersey, } \\
\text { Maryland and Delaware }\end{array}$ & $\begin{array}{l}\text { State of New York and a small part } \\
\text { of New Jersey }\end{array}$ \\
\hline $\begin{array}{l}\text { Proposed Date of } \\
\text { Operation }\end{array}$ & January 1,1998 (phased) & Mid 1997 (phased) & March 31, 1997 (phased) & Fourth quarter $1997 ?$ \\
\hline $\begin{array}{l}\text { Current Status of ISO } \\
\text { Proposal }\end{array}$ & $\begin{array}{l}\text { Phase I accepted, Phase II awaiting } \\
\text { approval }\end{array}$ & FERC Conditionally Approved & $\begin{array}{l}\text { Interim approval, some aspects still } \\
\text { being debated (pricing) }\end{array}$ & Not acted upon by FERC \\
\hline $\begin{array}{l}\text { Organization of the } \\
\text { ISO Development } \\
\text { effort }\end{array}$ & $\begin{array}{l}3 \text { TOs with broad stakeholder and } \\
\text { regulatory participation }\end{array}$ & NEPOOL, open process & PJM internal process & $\begin{array}{l}\text { Eight members of NYPP led } \\
\text { extensive collaborative process }\end{array}$ \\
\hline $\begin{array}{l}\text { Other Participants in } \\
\text { the Process }\end{array}$ & Stakeholders involved throughout. & Stakeholders involved throughout. & $\begin{array}{l}\text { Stakeholders more involved after } \\
\text { FERC compliance filing } 12 / 31 / 96\end{array}$ & Stakeholders, PSC \\
\hline
\end{tabular}




\begin{tabular}{|c|c|c|c|c|}
\hline int: & 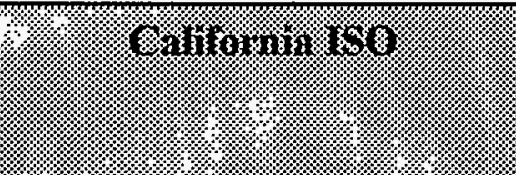 & IV) & 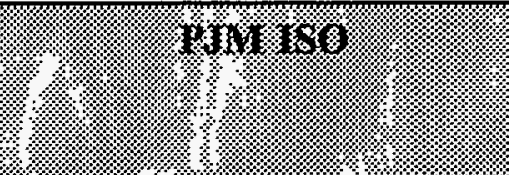 & i: \\
\hline $\begin{array}{l}\text { Organizational Form, } \\
\text { State of Incorporation }\end{array}$ & $\begin{array}{l}\text { California non profit public benefit } \\
\text { corporation }\end{array}$ & Non-profit, independent corporation & $\begin{array}{l}\text { Limited Liability Corporation, } \\
\text { Delaware }\end{array}$ & $\begin{array}{l}\text { Not-for-profit New York } \\
\text { corporation }\end{array}$ \\
\hline Non-Profit Status & non-profit & non-profit & & not-for-profit \\
\hline Location of Office & Sacramento, CA & Holyoke, Massachusetts & Norristown, Pennsylvania & \\
\hline $\begin{array}{l}\text { Relationship to Other } \\
\text { Organizations }\end{array}$ & $\begin{array}{l}\text { Oversight Board appoints ISO } \\
\text { Governing Board }\end{array}$ & $\begin{array}{l}\text { ISO currently operates under an } \\
\text { agreement with NEPOOL; complex } \\
\text { relationship between ISO and } \\
\text { NEPOOL committees }\end{array}$ & PJM, MAAC & $\begin{array}{l}\text { Simultaneously, NYPower } \\
\text { Exchange and NYS Reliability } \\
\text { Council to be created, NYPP } \\
\text { dissolved }\end{array}$ \\
\hline $\begin{array}{l}\text { Initial Capitalization, } \\
\text { source }\end{array}$ & & $\begin{array}{l}\text { NEPOOL has budgeted } \$ 26.5 \\
\text { million for the ISO first Operating } \\
\text { Year. }\end{array}$ & $\begin{array}{l}\$ 5.2 \text { million working capital needs; } \\
\text { will obtain financing or Members } \\
\text { will provide }\end{array}$ & \\
\hline \multicolumn{5}{|l|}{$\begin{array}{l}\text { Proposed Annual } \\
\text { Budget }\end{array}$} \\
\hline ISO Cost Recovery & $\begin{array}{l}\text { Grid Management Charge per kWH } \\
\text { includes amortized start-up and } \\
\text { development costs, annual } \\
\text { operating and financing costs }\end{array}$ & $\begin{array}{l}\text { Charges for scheduling, system } \\
\text { control and dispatch service set } \\
\text { forth in the Tariff. }\end{array}$ & & \\
\hline
\end{tabular}




\begin{tabular}{|c|c|c|c|c|}
\hline 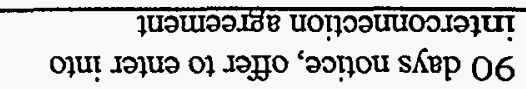 & әэпุou sরiвp 06 & 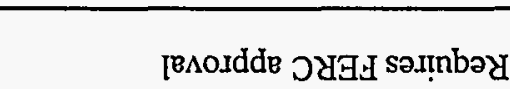 & 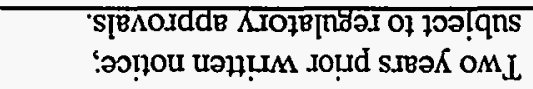 & $\begin{array}{r}\text { O.L J0 } \\
\text { OSI UONJ [BMEApq1!M }\end{array}$ \\
\hline pay!oads joN & paytords $70 \mathrm{~N}$ & 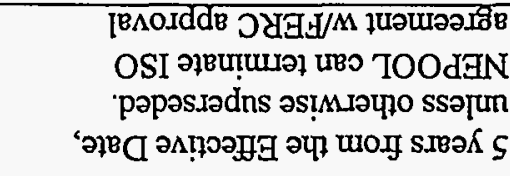 & 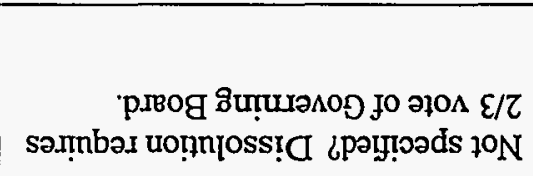 & 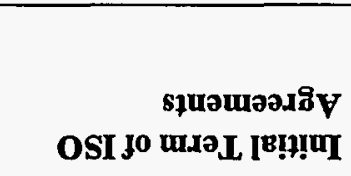 \\
\hline 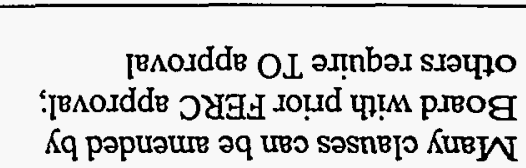 & 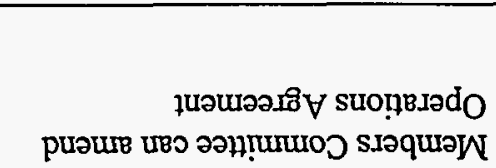 & 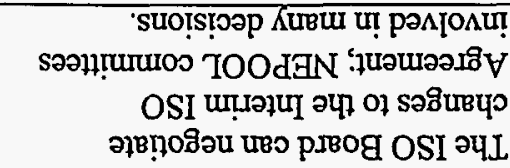 & 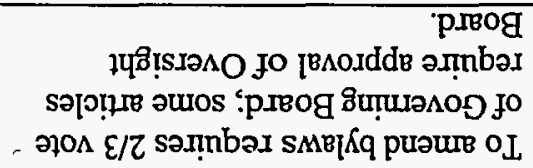 & 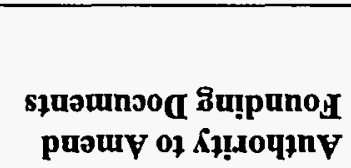 \\
\hline 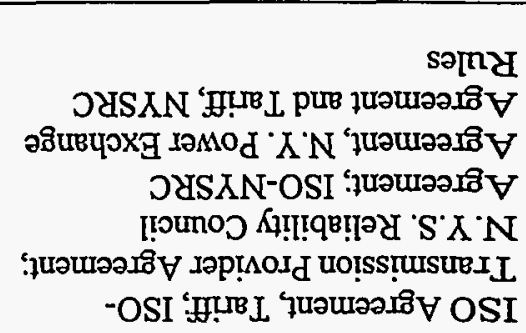 & 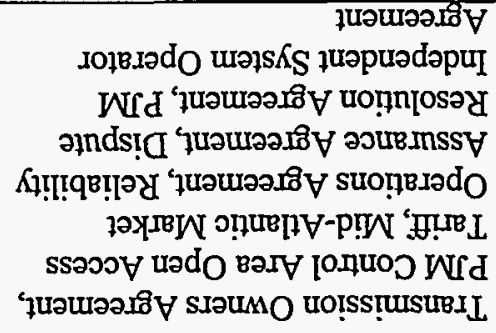 & 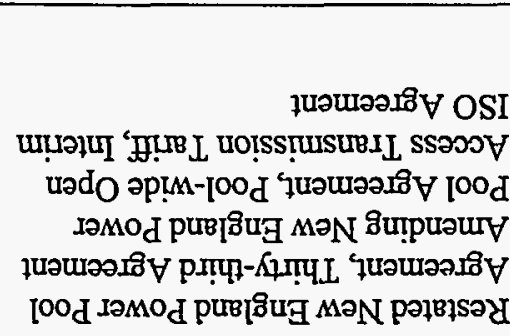 & 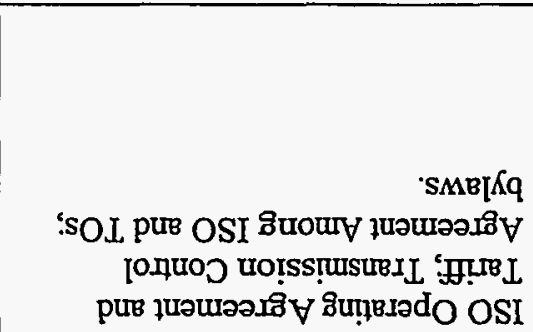 & squวunsop siụpunoH \\
\hline $9941 \times 1$ & 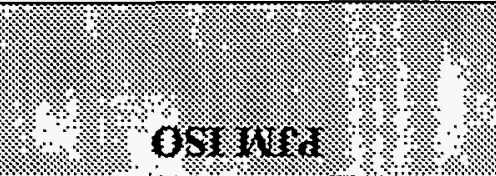 & : & I. & (1) \\
\hline
\end{tabular}




\begin{tabular}{|c|c|c|c|c|}
\hline 1. & ?: & 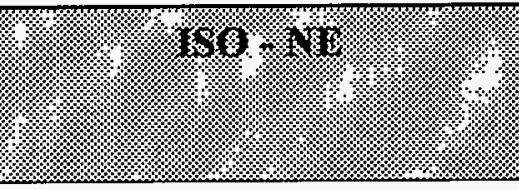 & 4. & ?: \\
\hline $\begin{array}{l}\text { Eligibility for } \\
\text { Membership }\end{array}$ & $\begin{array}{l}\text { Entities in } 13 \text { classes have a right to } \\
\text { participate in governing board } \\
\text { election process }\end{array}$ & $\begin{array}{l}\text { Any entity engaged in or proposing } \\
\text { to engage in wholesale or retail } \\
\text { electric business in New England; } \\
\text { end users will also be eligible. }\end{array}$ & $\begin{array}{l}\text { TOs, generators, distributors, end- } \\
\text { users, and any entity engaged in or } \\
\text { having intent to engage in buying, } \\
\text { selling or distributing electric } \\
\text { energy through PMM. }\end{array}$ & $\begin{array}{l}\text { Parties to ISO Agreement can be } \\
\text { TOs, Buyers, Sellers, or } \\
\text { Consumer/Environmental Groups }\end{array}$ \\
\hline $\begin{array}{l}\text { Authority of } \\
\text { Membership }\end{array}$ & $\begin{array}{l}\text { Nominate candidates for governing } \\
\text { board }\end{array}$ & $\begin{array}{l}\text { Representation on NEPOOL } \\
\text { committees }\end{array}$ & $\begin{array}{l}\text { Elect board, amend or terminate the } \\
\text { Operating Agreement }\end{array}$ & $\begin{array}{l}\text { Elect board; dispute resolution } \\
\text { committee. }\end{array}$ \\
\hline Membership Classes & $\begin{array}{l}13 \text { defined in bylaws (IOU; Muni; } \\
\text { Gov't marketer; non-utility sellers; } \\
\text { public buyers and sellers; private } \\
\text { buyers and sellers; Agric. end- } \\
\text { user; ind. end-user; comm. end- } \\
\text { user; res end-user; end-user at } \\
\text { large; public interest; non-market). }\end{array}$ & $\begin{array}{l}\text { 1) Large Investor Owned Utilities } \\
\text { whose voting shares greater than } \\
3 \% \text { of all NEPOOL Participants, } 2 \text { ) } \\
\text { smaller IOUs with voting shares } \\
\text { less than } 3 \% \text { of all NEPOOL } \\
\text { Participants, 3) munis and coops, 4) } \\
\text { NUGs, and 5) power marketers, } \\
\text { brokers and load aggregators. }\end{array}$ & $\begin{array}{l}\text { Transmission Owners, Generation } \\
\text { Owners, Other Suppliers, Electric } \\
\text { Distributors, End-Use Customers } \\
\text { Votes are weighted so that each } \\
\text { class gets an equal total weight. } 2 / 3 \\
\text { vote of membership required to } \\
\text { pass. }\end{array}$ & $\begin{array}{l}\text { Transmission Providers; Buyers; } \\
\text { Sellers; Consumer and } \\
\text { Environmental }\end{array}$ \\
\hline $\begin{array}{l}\text { Board of Directors } \\
\text { Composition }\end{array}$ & $\begin{array}{l}26 \text { governors appointed by } \\
\text { Oversight Board, as follows: } \\
\text { IOU: } 3 \text {; Muni: } 4 \text {; non-utility sellers } \\
\text { 2; res. end-users } 2 \text {; end-users at } \\
\text { large } 4 \text {; public interest } 2 \text {; non- } \\
\text { market } 2 \text {; all others } 1 \text { each. }\end{array}$ & $\begin{array}{l}10 \text { Directors, unaffiliated, } \\
\text { independent. Initially elected by } \\
\text { NEPOOL Executive Committee } \\
\text { based on slate from balanced } \\
\text { Nominating Committee, thereafter } \\
\text { Board elects replacements (self- } \\
\text { perpetuating). }\end{array}$ & $\begin{array}{l}7 \text { Managers, unaffiliated for past } \\
\text { five years, independent, elected by } \\
\text { Members from slate developed by } \\
\text { independent consultant. }\end{array}$ & $\begin{array}{l}\text { Original proposal: } 28 \text { Directors, } \\
\text { elected by class: } \\
\text { TOs, Buyers, Sellers each elect } 8 \\
\text { directors ; Consumer/Env. elect } 4 . \\
\text { [NYPP will soon file modified } \\
\text { proposal with independent } \\
\text { directors] }\end{array}$ \\
\hline Directors' Term & 3 years & & 2 years & 3 years \\
\hline Removal of Directors & $2 / 3$ vote of Governing Board & & $2 / 3$ vote of Members (see above) & \\
\hline $\begin{array}{l}\text { Affiliated directors } \\
\text { allowed? }\end{array}$ & Yes, most are affiliated & $\begin{array}{l}\text { No, must be unaffiliated and } \\
\text { independent. }\end{array}$ & $\begin{array}{l}\text { Must be unaffiliated, cannot have } \\
\text { worked for any Member past } 5 \mathrm{yrs} \text {. }\end{array}$ & $\begin{array}{l}\text { Original proposal: could be } \\
\text { affiliated. }\end{array}$ \\
\hline $\begin{array}{l}\text { Voting Mechanism for } \\
\text { Board decision- } \\
\text { making }\end{array}$ & Simple majority & $\begin{array}{l}\text { [Note: Many ISO procedures } \\
\text { developed within NEPOOL } \\
\text { committees] }\end{array}$ & Simple majority & $\begin{array}{l}\text { Affirmative vote of } 17 \text { of } 28 \\
\text { directors needed to pass }\end{array}$ \\
\hline
\end{tabular}




\begin{tabular}{|c|c|c|c|c|}
\hline 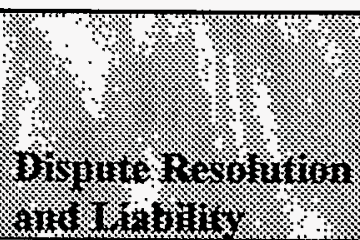 & (2: & (i) & S & i \\
\hline ADR Committee & Yes, shared with PX. & $\begin{array}{l}\text { NEPOOL dispute resolution } \\
\text { procedures }\end{array}$ & $\begin{array}{l}2 \text { reps each from ISO, Member } \\
\text { Committee, parties to Reliability } \\
\text { Assurance Agreement, parties to } \\
\text { TO Agreement }\end{array}$ & $\begin{array}{l}2 \text { reps each from TOs, Buyers, } \\
\text { Sellers, } 1 \text { rep from } \\
\text { consumer/environmental class }\end{array}$ \\
\hline $\begin{array}{l}\text { Who Appoints ADR } \\
\text { Mediator, Arbitrator? }\end{array}$ & $\begin{array}{l}\text { Parties to dispute, based on lists } \\
\text { provided by ADR Committee and } \\
\text { Am. Arb. Assoc. }\end{array}$ & $\begin{array}{l}\text { Am. Arb. Assoc. if parties cannot } \\
\text { agree. }\end{array}$ & $\begin{array}{l}\text { Parties to dispute, based on } \mathrm{ADR} \\
\text { Committee list. }\end{array}$ & $\begin{array}{l}\text { Parties based on ADR committee } \\
\text { list. P.S.C arbitrates disputes } \\
\text { between ISO and NYSRC }\end{array}$ \\
\hline FERC Final Appeal & Yes, according to defined process & Yes. & Yes & Yes if FERC jurisdictional \\
\hline ISO Liability & & $\begin{array}{l}\text { ISO not liable unless willfully } \\
\text { breached the Agreement or engaged } \\
\text { in willful misconduct. }\end{array}$ & If ISO found liable & $\begin{array}{l}\text { ISO, TOs, NYSRC not liable unless } \\
\text { gross negligence or intentional } \\
\text { misconduct }\end{array}$ \\
\hline TO Liability to ISO & $\begin{array}{l}\text { ISO, TO not liable to each other } \\
\text { unless negligent performance or } \\
\text { intentional breach. Not liable under } \\
\text { any circumstances for consequential } \\
\text { or indirect financial loss. }\end{array}$ & $\begin{array}{l}\text { The NEPOOL Participants shall not } \\
\text { be liable to the ISO for a failure to } \\
\text { perform under the terms of the } \\
\text { Agreement, unless that failure to } \\
\text { perform was a willful breach of the } \\
\text { Agreement. }\end{array}$ & $\begin{array}{l}\text { ISO indemnifies all members unless } \\
\text { willful misconduct }\end{array}$ & $\begin{array}{l}\text { TO not liable unless gross } \\
\text { negligence or willful misconduct }\end{array}$ \\
\hline ISO Insured? & Yes. & $\begin{array}{l}\text { The ISO shall procure insurance } \\
\text { required by applicable laws. }\end{array}$ & $\begin{array}{l}\text { Yes. ISO liability not covered by } \\
\text { insurance passed on as Scheduling } \\
\text { Service }\end{array}$ & Yes \\
\hline
\end{tabular}




\begin{tabular}{|c|c|c|c|c|}
\hline (15: & r্য & ilis: & ili: & ? \\
\hline $\begin{array}{l}\text { Transfer of control of } \\
\text { facilities }\end{array}$ & Transmission control agreement & $\begin{array}{l}\text { Restated NEPOOL Agreement } \\
\text { transfers control to ISO }\end{array}$ & Operating Agreement & $\begin{array}{l}\text { Agreement Between Transmission } \\
\text { Providers and ISO }\end{array}$ \\
\hline $\begin{array}{l}\text { Facilities Under ISO } \\
\text { Control }\end{array}$ & $\begin{array}{l}\text { Transmission network and } \\
\text { associated facilities; w/o directly } \\
\text { assignable radial lines. ISO can } \\
\text { apply to FERC to gain control of } \\
\text { additional facilities as needed. } \\
\text { Temporary control over additional } \\
\text { facilities as needed to prevent or } \\
\text { remedy emergency. }\end{array}$ & $\begin{array}{l}\text { Lines rated } 69 \mathrm{kV} \text { or above (except } \\
\text { for generation leads and certain } \\
\text { radial lines) which are owned by } \\
\text { NEPOOL Participants. }\end{array}$ & $\begin{array}{l}\text { Lines rated } 230 \mathrm{kV} \text { and other key } \\
\text { transmission facilities. } \\
\text { ISO also dispatches generation. }\end{array}$ & $\begin{array}{l}\text { Generally } 115 \mathrm{kV} \text { and up, with } \\
\text { exceptions. }\end{array}$ \\
\hline $\begin{array}{l}\text { One Control Area or } \\
\text { Multiple? }\end{array}$ & One control area. & $\begin{array}{l}\text { Multiple control centers (satellites) } \\
\text { currently operate, eventually may } \\
\text { operate as one. }\end{array}$ & One & One \\
\hline $\begin{array}{l}\text { ISO has Direct } \\
\text { Control of Facilities? }\end{array}$ & $\begin{array}{l}\text { ISO directs TOs to physically } \\
\text { operate facilities. }\end{array}$ & $\begin{array}{l}\text { Satellites are responsible for } \\
\text { regional transmission security } \\
\text { analysis, switching and tagging, and } \\
\text { implementation of applicable } \\
\text { System Rules and Procedures. }\end{array}$ & Yes, single control area & $\begin{array}{l}\text { Yes, controls transmission and also } \\
\text { generation operating under Security } \\
\text { Constrained Dispatch or providing } \\
\text { ancillary services (as in NYPP). } \\
\text { TOs do actual switching. }\end{array}$ \\
\hline $\begin{array}{l}\text { TO control, } \\
\text { responsibility }\end{array}$ & $\begin{array}{l}\text { TOs follows ISO directions unless } \\
\text { the health or safety of persons } \\
\text { endangered. }\end{array}$ & Operate satellite control centers & $\begin{array}{l}\text { TOs can adopt procedures to protect } \\
\text { their facilities, etc. }\end{array}$ & Operates local control center \\
\hline
\end{tabular}




\begin{tabular}{|c|c|c|c|c|}
\hline 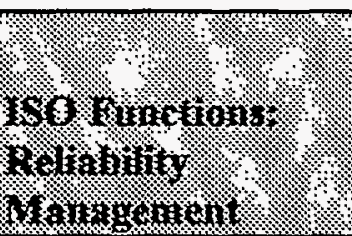 & ? & S & ?্য & : \\
\hline $\begin{array}{l}\text { ISO is NERC Security } \\
\text { Coordinator? }\end{array}$ & $\begin{array}{l}\text { ISO is designated WSCC Security } \\
\text { Coordinator for the ISO controlled } \\
\text { grid. }\end{array}$ & $\begin{array}{l}\text { Apparently, but not explicit in } \\
\text { founding documents }\end{array}$ & $\begin{array}{l}\text { Apparently, but not explicit in } \\
\text { founding documents }\end{array}$ & $\begin{array}{l}\text { Apparently, but not explicit in } \\
\text { founding documents }\end{array}$ \\
\hline $\begin{array}{l}\text { ISO Authority to } \\
\text { Resolve Reliability } \\
\text { Problems }\end{array}$ & $\begin{array}{l}\text { ISO will coordinate, authorize, and } \\
\text { direct, as appropriate, switching, } \\
\text { outages, clearances and scheduling } \\
\text { of ISO controlled grid facilities. }\end{array}$ & $\begin{array}{l}\text { The ISO shall have primary } \\
\text { responsibility for ensuring short- } \\
\text { term reliability of the System } \\
\text { consistent with the applicable } \\
\text { standards set by NERC and NPCC. }\end{array}$ & $\begin{array}{l}\text { Control area operator, has authority } \\
\text { according to PJM procedures }\end{array}$ & $\begin{array}{l}\text { ISO responsible for reliability, } \\
\text { including implementation of } \\
\text { procedures for curtailment, load } \\
\text { shedding, and maintenance. }\end{array}$ \\
\hline $\begin{array}{l}\text { ISO Authority Under } \\
\text { Emergency } \\
\text { Circumstances }\end{array}$ & $\begin{array}{l}\text { Authority to control facilities, loads } \\
\text { and gerieration, including } \\
\text { transmission not part of ISO } \\
\text { controlled grid. }\end{array}$ & $\begin{array}{l}\text { The ISO may direct any NEPOOL } \\
\text { Participant to take any action } \\
\text { necessary to preserve reliable } \\
\text { operation of NEPOOL Control } \\
\text { Area. }\end{array}$ & $\begin{array}{l}\text { Declare emergency, direct } \\
\text { operations of Participants as } \\
\text { necessary to alleviate, including } \\
\text { curtailment, to preserve reliability in } \\
\text { accordance with NERC and MAAC } \\
\text { principles, guidelines, standards }\end{array}$ & $\begin{array}{l}\text { Declare emergency, direct actions of } \\
\text { TOs and market participants to } \\
\text { respond to emergency. }\end{array}$ \\
\hline $\begin{array}{l}\text { ISO Role in } \\
\text { Developing Reliability } \\
\text { Procedures }\end{array}$ & $\begin{array}{l}\text { ISO develops Operating Procedures } \\
\text { and Reliability Criteria in } \\
\text { compliance with NERC, WSCC, } \\
\text { and local criteria of TOS. ISO } \\
\text { develops and issues protocols for } \\
\text { System Emergencies, administers } \\
\text { periodic unannounced tests of the } \\
\text { procedures. }\end{array}$ & $\begin{array}{l}\text { Yes. ISO shall initially operate in } \\
\text { accordance with the CRS and } \\
\text { Operating Procedures as currently } \\
\text { in effect. The ISO may propose to } \\
\text { implement such changes to the CRS } \\
\text { and Operating Procedures as it may } \\
\text { deem necessary or advisable. }\end{array}$ & $\begin{array}{l}\text { Not clear. Complies with NERC } \\
\text { and MAAC principles and } \\
\text { standards. } \\
\text { ISO is responsible for monitoring } \\
\text { compliance. }\end{array}$ & $\begin{array}{l}\text { NYSRC adopts and modified rules } \\
\text { that are binding on the ISO. ISO } \\
\text { implements and administers } \\
\text { NYSRC criteria and standards. } \\
\text { ISO develops maintenance and } \\
\text { curtailment procedures. }\end{array}$ \\
\hline
\end{tabular}




\begin{tabular}{|c|c|c|c|c|}
\hline 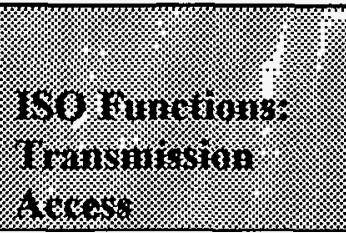 & 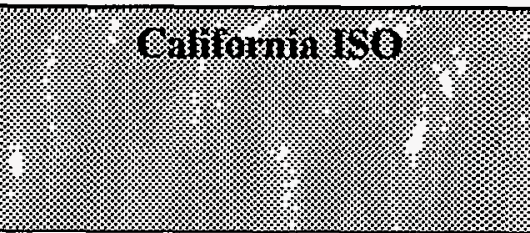 & ?: & : & 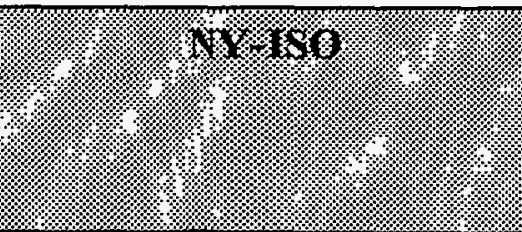 \\
\hline $\begin{array}{l}\text { Operate OASIS, } \\
\text { computes ATC }\end{array}$ & ISO & ISO & ISO & ISO \\
\hline $\begin{array}{l}\text { Reserve Transmission } \\
\text { Services }\end{array}$ & ISO & ISO & ISO & ISO \\
\hline $\begin{array}{l}\text { Congestion } \\
\text { Management } \\
\text { Approach }\end{array}$ & $\begin{array}{l}\text { Zonal approach. ISO provides } \\
\text { information, may frcilitate voluntary } \\
\text { trades among Schedule } \\
\text { Coordinators to relieve anticipated } \\
\text { congestion. Otherwise ISO } \\
\text { allocates scarce capacity based on } \\
\text { Adjustment Bids, adjusting } \\
\text { schedules only as necessary to } \\
\text { alleviate congestion. }\end{array}$ & $\begin{array}{l}\text { ISO dispatches out-of-merit } \\
\text { resources that are bid by the } \\
\text { Participants in any hour when } \\
\text { limitations in available transmission } \\
\text { capacity require. }\end{array}$ & $\begin{array}{l}\text { Locational marginal pricing (ISO is } \\
\text { also a power exchange). }\end{array}$ & $\begin{array}{l}\text { Resolves congestion in day-ahead or } \\
\text { hourly markets utilizing voluntary } \\
\text { increment or decrement bids. }\end{array}$ \\
\hline $\begin{array}{l}\text { Billing and collection } \\
\text { for transmission } \\
\text { service }\end{array}$ & ISO & ISO & ISO & ISO \\
\hline
\end{tabular}




\begin{tabular}{|c|c|c|c|c|}
\hline MO & ( & S: & 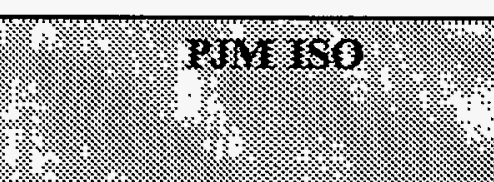 & 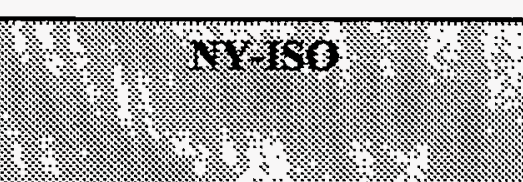 \\
\hline $\begin{array}{l}\text { Determination of } \\
\text { Quantities, Locations } \\
\text { Required }\end{array}$ & $\begin{array}{l}\text { ISO Ancillary Services standards } \\
\text { based on WSCC and ISO reliability } \\
\text { requirements, developed to } \\
\text { determine reasonableness, cost } \\
\text { effectiveness, and adherence to } \\
\text { national and WSCC standards. }\end{array}$ & NEPOOL and ISO & ISO according to PJM procedures & ISO \\
\hline $\begin{array}{l}\text { Who Provides } \\
\text { Ancillary Service? }\end{array}$ & $\begin{array}{l}\text { ISO, self-provision, 3rd party. ISO } \\
\text { operates markets for ancillary } \\
\text { services, will competitively procure } \\
\text { them if not self-provided. } \\
\text { Regulation, Spinning, Non-spinning } \\
\text { and Replacement reserves procured } \\
\text { on daily and hourly basis, and } \\
\text { Replacement reserve on longer term } \\
\text { basis as necessary to meet reliability } \\
\text { criteria. Voltage Support and Black } \\
\text { Start contracted longer term }\end{array}$ & $\begin{array}{l}\text { ISO or self-provision, including } \\
\text { third party. Transmission customer } \\
\text { cannot decline ISO's offer of } \\
\text { ancillary services unless he can } \\
\text { demonstrate that he has acquired } \\
\text { ancillary services of equal quality } \\
\text { from another source. }\end{array}$ & $\begin{array}{l}\text { ISO provides or coordinates } \\
\text { provision based on least-cost } \\
\text { principles. }\end{array}$ & $\begin{array}{l}\text { ISO or self-provision. ISO procures } \\
\text { on a competitive basis where } \\
\text { possible. }\end{array}$ \\
\hline $\begin{array}{l}\text { Who Monitors that } \\
\text { Anc. Services are } \\
\text { Provided? }\end{array}$ & ISO & ISO & ISO & ISO \\
\hline $\begin{array}{l}\text { Billing, collection for } \\
\text { anc. sves }\end{array}$ & $\begin{array}{l}\text { ISO calculates charges, bills } \\
\text { Scheduling Coordinators. }\end{array}$ & ISO & ISO & ISO \\
\hline
\end{tabular}




\begin{tabular}{|c|c|c|c|c|}
\hline \multicolumn{2}{|c|}{ 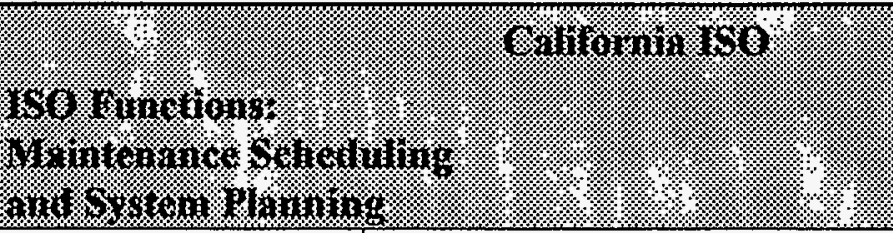 } & 4ut & \multicolumn{2}{|c|}{ 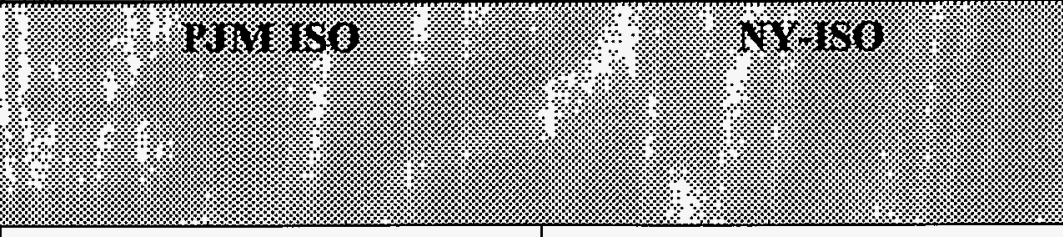 } \\
\hline $\begin{array}{l}\text { ISO Role in } \\
\text { Transmission } \\
\text { Maintenance } \\
\text { Scheduling }\end{array}$ & $\begin{array}{l}\text { ISO coordinates, approves } \\
\text { maintenance schedules unless } \\
\text { detrimental effect on the efficient } \\
\text { use and reliable operation of ISO } \\
\text { controlled grid. ISO can also } \\
\text { request maintenance. ISO develops } \\
\text { maintenance standards. }\end{array}$ & $\begin{array}{l}\text { ISO oversees the scheduling of } \\
\text { maintenance of the Designated } \\
\text { Transmission Facilities in } \\
\text { conformance with the System Rules } \\
\text { and Procedures. }\end{array}$ & $\begin{array}{l}\text { ISO coordinates and approves, } \\
\text { including coordination with related } \\
\text { generation outages. }\end{array}$ & $\begin{array}{l}\text { ISO receives schedules, maintains } \\
\text { confidentiality. If schedule would } \\
\text { adversely affect reliable operation, } \\
\text { ISO advises, TO reschedules. ISO } \\
\text { can ultimately propose three } \\
\text { alternate schedules and require that } \\
\text { TO select one. }\end{array}$ \\
\hline $\begin{array}{l}\text { ISO Role in } \\
\text { Generation } \\
\text { Maintenance } \\
\text { Scheduling }\end{array}$ & $\begin{array}{l}\text { ISO coordinates; collects } \\
\text { information and reports, including } \\
\text { forecast of congestion. Reliability } \\
\text { must-run units require ISO } \\
\text { approval. }\end{array}$ & $\begin{array}{l}\text { ISO oversees the scheduling of } \\
\text { maintenance of the Designated } \\
\text { Generation Facilities in } \\
\text { conformance with the System Rules } \\
\text { and Procedures. }\end{array}$ & $\begin{array}{l}\text { ISO coordinates and approves } \\
\text { generator maintenance schedules }\end{array}$ & $\begin{array}{l}\text { ISO assesses impact on reliability of } \\
\text { generator maintenance, informs } \\
\text { market of potential reliability } \\
\text { impacts. Generators providing } \\
\text { Installed Capacity must have } \\
\text { maintenance approved by ISO }\end{array}$ \\
\hline $\begin{array}{l}\text { ISO Role in Regional } \\
\text { Planning }\end{array}$ & $\begin{array}{l}\text { Coordinated planning process } \\
\text { involves ISO, TOs, market } \\
\text { participants. }\end{array}$ & $\begin{array}{l}\text { NEPOOL has lead role. ISO has } \\
\text { authority to independently conduct } \\
\text { System assessment and planning } \\
\text { and convey its findings to NEPOOL. }\end{array}$ & $\begin{array}{l}\text { ISO prepares Regional } \\
\text { Transmission Expansion Plan } \\
\text { w/participation of interested parties; } \\
\text { Board approves. }\end{array}$ & $\begin{array}{l}\text { Planning occurs largely at initiative } \\
\text { of market participants, expansion } \\
\text { largely at their expense. ISO } \\
\text { performs studies including forecast } \\
\text { of near-term transm. adequacy. }\end{array}$ \\
\hline $\begin{array}{l}\text { ISO Can Compel TOs } \\
\text { to Build? }\end{array}$ & $\begin{array}{l}\text { TOs obligated to build if needed for } \\
\text { efficiency or reliability subject to } \\
\text { approvals, cost recovery. Any party } \\
\text { can be a Project Sponsor, and if } \\
\text { willing to pay costs, that is sufficient } \\
\text { to establish need. }\end{array}$ & $\begin{array}{l}\text { NEPOOL can obligate TOs to build } \\
\text { when required to provide requested } \\
\text { service. }\end{array}$ & Yes & $\begin{array}{l}\text { No. ISO and NYSRC can } \\
\text { recommend to TOs but not order. }\end{array}$ \\
\hline Who Builds? & $\begin{array}{l}\text { TOs. Other entities not excluded } \\
\text { from building and owning. ISO will } \\
\text { pursue eminent domain authority to } \\
\text { facilitate this. }\end{array}$ & TOs or other entity. & TOs, or they may contract out. & TOs or third parties \\
\hline $\begin{array}{l}\text { Long Term } \\
\text { Generating Capacity } \\
\text { Reserve Requirement? }\end{array}$ & & Installed Capability Responsibility & $\begin{array}{l}\text { Current 2-year advance reserve } \\
\text { commitment phases down to } 3 \text { - } \\
\text { months for Load Serving Entities }\end{array}$ & $\begin{array}{l}\text { NYSRC sets statewide reserve } \\
\text { req't, LSEs required to meet reserve } \\
\text { req't on a year-ahead basis. }\end{array}$ \\
\hline
\end{tabular}




\begin{tabular}{|c|c|c|c|c|}
\hline 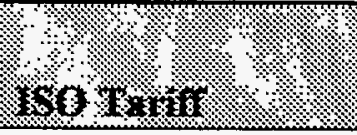 & (4) & 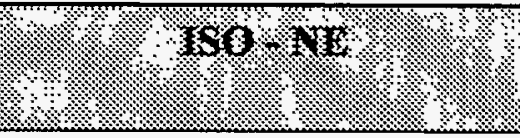 & (4) & (. \\
\hline $\begin{array}{l}\text { Transmission } \\
\text { Charges: Approach }\end{array}$ & $\begin{array}{l}\text { Zonal based on service territories to } \\
\text { recover revenue requirement }\end{array}$ & $\begin{array}{l}\text { Postage stamp regional access } \\
\text { charges after transition period. }\end{array}$ & $\begin{array}{l}\text { Zonal for network service. ISO is } \\
\text { also a pool, uses locational marginal } \\
\text { pricing. }\end{array}$ & $\begin{array}{l}\text { Zonal Transmission Service Charge } \\
\text { based on service territory of } \\
\text { customer. }\end{array}$ \\
\hline Wheeling Into & Zonal access charge & & Zonal rate & Zonal Transm. Svc. Charge \\
\hline $\begin{array}{l}\text { Wheeling Through, } \\
\text { Out }\end{array}$ & $\begin{array}{l}\text { TO-specific wheeling access charge } \\
\text { based on exit point }\end{array}$ & $\begin{array}{l}\text { Higher of "pool PTF rate" } \\
\text { (aggregate revenue req"t divided by } \\
\text { aggregate coincident peak) or } \\
\text { incremental annual cost of new } \\
\text { facilities required to provide the } \\
\text { service }\end{array}$ & Point-to-point rate at exit point & $\begin{array}{l}\text { Transmission Service Charge } \\
\text { applicable at exit point. }\end{array}$ \\
\hline Revenue Allocation & $\begin{array}{l}\text { Proportional to revenue } \\
\text { requirements }\end{array}$ & & Revenue requirements & Revenue requirements \\
\hline $\begin{array}{l}\text { Congestion Charges: } \\
\text { Approach }\end{array}$ & $\begin{array}{l}\text { Users of inter-zonal congested } \\
\text { interfaces pay, and providers of } \\
\text { relief receive, the hourly marginal } \\
\text { value of transfer capacity. } \\
\text { For intra-zonal redispatch, } \\
\text { payments or charges are according } \\
\text { to adjustment bids. }\end{array}$ & $\begin{array}{l}\text { Congestion costs resulting from out- } \\
\text { of-merit dispatch to resolve } \\
\text { congestion calculated and allocated } \\
\text { by hour and area. }\end{array}$ & $\begin{array}{l}\text { Locational marginal pricing for } \\
\text { energy and transmission reflects } \\
\text { congestion. }\end{array}$ & $\begin{array}{l}\text { Locational energy pricing reflects } \\
\text { congestion and losses; neutral } \\
\text { between power exchange and } \\
\text { bilateral transactions. }\end{array}$ \\
\hline $\begin{array}{l}\text { Recovery of New } \\
\text { Investment: Approach }\end{array}$ & $\begin{array}{l}\text { Rolled into access charge of TO } \\
\text { unless beneficiaries can be } \\
\text { identified. }\end{array}$ & $\begin{array}{l}\text { Some costs allocated to particular } \\
\text { users, others allocated based on load } \\
\text { ratio. }\end{array}$ & $\begin{array}{l}\text { Costs for some facilities allocated to } \\
\text { all TOs, others to TO in whose zone } \\
\text { facilities located. }\end{array}$ & $\begin{array}{l}\text { TOs and market participants, who } \\
\text { would receive firm capacity rights }\end{array}$ \\
\hline
\end{tabular}

